\section{Sr Isotope Analysis of Human Remains from Settlement Pits at Stillfried/ March. Reappraising Diagenetic Changes}

\author{
Anika Retzmann* \\ Anna-Maria Kriechbaum* \\ Monika Griebl \\ Karin Wiltschke-Schrotta \\ Maria Teschler-Nicola \\ Johanna Irrgeher \\ Thomas Prohaska
}

\begin{abstract}
Objectives: Since the late 1970s, when the first human skeletal remains from a pit (V1141) located within the Late Bronze Age hillfort at Stillfried an der March, Austria, were discovered, their deviation from the predominant burial rite of cremation became the subject-matter of a variety of archaeological and bioanthropological studies. Through continuous archaeological excavations, further settlement pits with unusual human inhumation burials or depositions of isolated skeletal remains became apparent and posed the question of their possible non-local origin. The human samples in this study come from the Pits V841 and V1133, furthermore we re-investigate two individuals from V1141. The aim is to get a better understanding of Stillfried's population structure and to enrich the debate about the mortuary practices of the Urnfield culture.

Material and Methods: Here we present and discuss the radiogenic Sr isotope ratios determined in the enamel of eleven individuals from three settlement pits: eight individuals from Pit V841 and one individual, represented by a skull without mandible (calvarium) of a 12-13-year-old child from Pit V1133; two individuals were taken from Pit V1141 and re-investigated for comparative reasons. We compared all data to signals of the local environment derived from modern environmental samples and to the autochthonous signal of the Late Bronze Age derived from archaeological faunal remains (incl. mussels) and archaeological plants. Further, we investigated and discussed the potential of a mathematical approach to access biogenic Sr isotopic information from diagenetically altered dentine.

Results: It has been shown that both supposedly autochthonous and allochthonous (non-local) individuals are buried within the settlement pits of Stillfried, which shows that burial practices do not relate to the individual's origins. In particular, the $n\left({ }^{87} \mathrm{Sr}\right) / n\left({ }^{86} \mathrm{Sr}\right)$
\end{abstract}

isotopic values of six individuals match the supposedly autochthonous $\mathrm{Sr}$ signature, while the other five individuals represent allochthonous individuals. Three of the latter showed $n\left({ }^{87} \mathrm{Sr}\right) / n\left({ }^{86} \mathrm{Sr}\right)$ values that were higher and two that were lower compared to the autochthonous Sr range, thereby indicating at least two different homelands. Despite the small sample size which constrains the validity of the data, the diversity of the inhabitants' provenance reflects a high mobility. This may support the interpretation of Stillfried as a 'central site' - a finding which is also important in the wider context of the European Late Bronze Age.

\section{Keywords}

Deviant burials, hillfort site, human skeletal remains, Late Bronze Age, Urnfield Culture, Stillfried/Lower Austria, Strontium isotopes, diagenetic alterations.

Zusammenfassung - Sr-Isotopenanalyse menschlicher Skelettreste aus Siedlungsgruben in Stillfried/March. Überprüfung der diagenetischen Veränderungen

Ziel: Seit den späten 1970er Jahren, als die ersten menschlichen Skelettreste aus einer Siedlungsgrube (V1141) der spätbronzezeitlichen Wallanlage von Stillfried an der March geborgen wurden, stand deren Abweichung von der üblichen Leichenverbrennung im Brennpunkt archäologischer und bioanthropologischer Forschung. Durch fortdauernde archäologische Ausgrabungen wurden weitere Siedlungsgruben mit ungewöhnlichen Bestattungen menschlicher Körper oder Niederlegungen einzelner Skelettreste freigelegt, die die Frage nach ihrer möglichen nicht-lokalen Herkunft aufwarfen. Die menschlichen Proben dieser Studie kommen aus den Gruben V841 und V1133, darüber hinaus untersuchten wir erneut zwei Individuen 
aus V1141. Ziel ist es, ein besseres Verständnis von Stillfrieds Bevölkerungsstruktur zu erhalten und die Debatte über die Bestattungspraktiken der Urnenfelderkultur zu bereichern.

Material und Methode: Hier präsentieren und diskutieren wir die im Zahnschmelz bestimmten Sr-Isotopenverhältnisse von elf Individuen aus drei Siedlungsgruben: acht Individuen aus Grube V841 und ein 12-13-jähriges Kind aus Grube V1133, von dem nur der Schädel ohne Unterkiefer (Calvarium) erhalten ist. Zwei weitere, aus Siedlungsgrube V1141 geborgene Individuen mit bereits bekannten SrIsotopensignaturen wurden für Vergleichszwecke ebenfalls einbezogen. Wir verglichen alle Daten mit Sr-Werten, die wir aus der lokalen Umgebung und aus urnenfelderzeitlichen Faunen- und Pflanzenresten (einschließlich Muscheln) gewonnen haben. Darüber hinaus untersuchen und diskutieren wir das Potential eines mathematischen Ansatzes für die Ermittlung biogener Sr-Isotopen-Informationen aus diagenetisch verändertem Dentin.

Ergebnisse: Die menschlichen Überreste in den Siedlungsgruben von Stillfried stammen sowohl von ansässigen Personen als auch von Individuen anderer Herkunft, was zeigt, dass die Bestattungspraktiken nicht mit der Herkunft des Individuums zusammenhängen. Konkret entsprechen die Sr-Isotopenwerte von sechs Individuen der autochthonen Sr-Signatur, während die Werte der restlichen fünf Individuen auf eine Herkunft außerhalb von Stillfried verweisen, also allochthone Individuen darstellen. Drei der allochthonen Individuen zeigen höhere Sr-Isotopensignaturen im Vergleich zur autochthonen Sr-Signatur, die restlichen zwei allochthonen Individuen niedrigere Sr-Isotopensignaturen. Dies weist auf mindestens zwei unterschiedliche Herkunftsgebiete hin, was für die Interpretation der Siedlungsbestattungen in der Wallanlage von Stillfried von Bedeutung ist, da die daraus abzuleitende hohe Mobilität auch den Charakter der Siedlung als „Zentralort“ unterstreicht. Auch im Kontext der überregionalen populationsdynamischen Entwicklungsprozesse in der europäischen Spätbronzezeit ist dieses Resultat von großer Relevanz. Die Ergebnisse dieser Studie basieren auf einer ausgewählten, kleinen Stichprobe. Ihre Aussagekraft in Bezug auf Fragen zur Bevölkerungsstruktur des spätbronzezeitlichen Stillfried ist dementsprechend begrenzt.

\section{Schlüsselbegriffe}

Sonderbestattungen, Wallanlage, menschliche Skelettreste, späte Bronzezeit, Urnenfelderkultur, Stillfried/Niederösterreich, Strontiumisotopie, diagenetische Veränderungen.

\section{Introduction}

\subsection{Archaeological Background}

The Late Bronze Age hillfort of Stillfried an der March, known since the $19^{\text {th }}$ century, was systematically explored between 1969 and 1989 as part of extensive field excavations under the direction of Fritz Felgenhauer. ${ }^{1}$ A multitude of structures, e.g., a fortification system and about 100 voluminous settlement pits, were uncovered and point to a 'central site', which developed on an important trade route. Striking features of the Stillfried site are the deviant human burials with unburned human skeletons and animal depositions in about twenty of these abandoned storage pits.

\footnotetext{
1 Felgenhauer 1996.
}

These findings have been the subject of several interdisciplinary research projects focusing on the historical development of this particular 'living space' and its inhabitants. Experts revealed, among other things, individual data (age at death, sex, pathological alterations, cause of death); they dealt with questions concerning residence, provenance and familial relationship and reflected on possible reasons for the deviant treatment of the deceased in conjunction with social status, group relation or non-local origin. To date, many, but far from all questions have been deciphered. ${ }^{2}$

According to Irmtraud Hellerschmid, ${ }^{3}$ the scenarios reflected in the archaeological records, particularly in the backfills of the storage pits, indicate not only production-related activities, but ritual practices as well. The explanation of these ritual practices varies; some associate these findings with a different provenance, for example, some with homicide or human sacrifice, and others with a possible social diversity of the residents.

Although the provenance of the individuals receiving a deviant burial is a core element in the debate on such an entity, up to now we only possess knowledge about the origins of seven individuals from Pit V1141 obtained through the Sr isotope analysis of tooth enamel. ${ }^{4}$ Hence, the present study aims to continue and expand the isotope investigation by including further individuals from the site buried in a deviant manner to acquire a deeper insight into the population formation of the Late Bronze Age society at Stillfried. For the given study, we included individuals from three settlement pits: ${ }^{5}$ Pits V841 and V1141 with multiple inhumations and Pit V1133, where one isolated human skull without its mandible (calvarium) was recovered. The skeleton of an elderly woman from pit house V601 was not available for examination. The settlement pits from which the investigated individuals originated were located in the highest area of the hilltop site ('Hügelfeld' and 'Kirchhügel') close to the rampart (Fig. 1). Based on the averages of ${ }^{14} \mathrm{C}$ data ${ }^{6}$ and

2 Breitinger 1980.-Eibner 1980.-Eibner 1988.-Szilvássy, KritSCher, Hauser 1988. - Hellerschmid 2015. - Teschler-Nicola, Irrgeher, Prohaska 2016. - Parson et al. 2018. - Hellerschmid, Griebl in prep. - WiltschKe-Schrotta, Marschler in prep.

3 Hellerschmid 2015, 206, 219, 222, 227-228.

4 Teschler-Nicola, Irrgeher, Prohaska 2016.

5 Griebl, Hellerschmid 2013.

$6{ }^{14} \mathrm{C}$ data: 1/V1141: Man SK 1 (sign. 09023): VERA-2918: $2745 \pm 35$ [980-810 BC (95.4 \%)]; 2/V1141: Child SK 7 (sign. 09029): VERA2919: $3000 \pm 35$ [1380-1120 BC (95.4\%)]; 3/V1141: Human bone no. 9208 (sign. 09030, layer above the burial): Poz-78217: $2770 \pm 30 \mathrm{BP}$ [997-839 BC (95.4 \%)]; 1/V841: Man SK 1 (sign. 09041): Poz-59980: $2735 \pm 30$ BP [970-814 BC (95.4\%)]; 2/V841: Child SK 12 (sign. 09053): Poz-59981: $2770 \pm 30$ [998-838 BC (95.4 \%)]. - HellersCHmid 2006, 293. - Griebl, Biederer in prep., Chapter 1.4.2 and Figs. 30-32. 


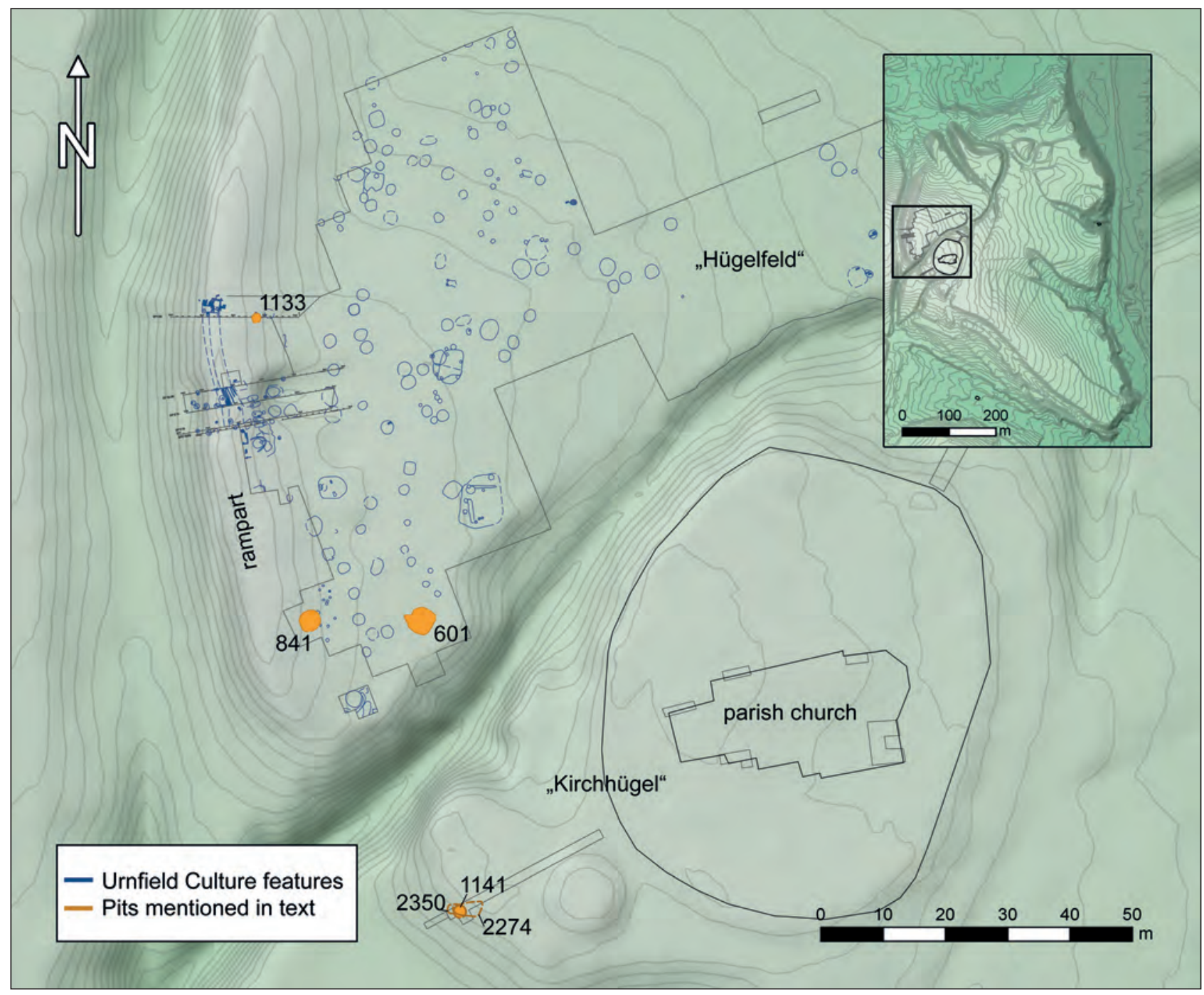

Fig. 1. Map of the hillfort site at Stillfried/March with the Late Urnfield Culture findings, most of them are conical pits. The findings with human remains which are mentioned in the text (V601, V841, V1133, V1141) are coloured (processed by ARDIG, I. Hellerschmid, I. Petschko and S. Tikatsch).

the archaeological classification, ${ }^{7}$ the Pits V841 and V1141 were dated to the same period, around $900 \mathrm{BC}$. This is the transition from Reinecke $\mathrm{Ha} \mathrm{B}{ }^{8}$ to $\mathrm{Ha} \mathrm{B} 3^{9}$. It correlates well with the transition of the Stillfried-settlement phase II ${ }^{10}$ (with the first rampart construction V1267) to the Stillfried-settlement phase III/ $1^{11}$ (this is the beginning of the

7 Hellerschmid 2006. - Griebl, Biederer in prep.

8 960-900 BC after SPERber 2017, 171 and Fig. 72C.

9 Sperber 2017 separates this phase into Ha B3a (900-850/840 BC) and Ha B3b (850/840-800/780 BC): SPERBER 2017, 171 and Fig. 72C. 10 Ha B2 (after Sperber 2017, 960-900 BC), Hellerschmid 2006, 22-23. - Hellerschmid, Griebl in prep.

11 Ha B3a (after Sperber 2017, 900-850/840 BC), Hellerschmid 2006, 22-23. - Hellerschmid, Griebl in prep. second and final rampart construction V1154). While the multiple inhumations are chronologically consistent with the cremation burials at the cemetery in the valley nearby, ${ }^{12}$ the two ${ }^{14} \mathrm{C}$ dates ${ }^{13}$ of the child (V1133) are slightly older, corresponding to Reinecke Ha B2 and Stillfried-settlement phase II. The third ${ }^{14} \mathrm{C}$ date determined for an animal bone ${ }^{14}$ from V1133 and the archaeological dating of V1133 fit with the results of the ${ }^{14} \mathrm{C}$ dating of Pits V841 and V1141. This

12 Strohschneider 1976. - Kaus 1984.

13 Poz-59987: $2810 \pm 30$ BP [1050-860 BC (95.4 \%)]; VERA-2917: $2810 \pm 35$ BP [1050-830 BC (95.4\%)].

14 Poz-59943: $2770 \pm 30$ BP [998-838 BC (95.4 \%)]. - Griebl, BIEDERER in prep. 
means that the child died years before its calvarium became embedded in the pit.

Based on the fact that cremation of the deceased was the norm in the Late Bronze Age, we suspect that these individuals buried in a deviant manner might represent migrants, i.e., non-locals. Therefore, the present study aims to identify the provenance of further individuals from Pits V841 and V1133 (and to re-investigate two samples from V1141 for comparative reasons) to verify the hypothesis that burial practices relate to the individual's origins. The results are of paramount importance for decoding the internal population structure of this 'central site', which was possibly associated with its economic rise. We also intend to discuss and compare the findings with other studies of Late Bronze Age societies that seem to indicate social inequality and substantial mobility documented by a significant number of incorporated immigrants. ${ }^{15}$

\subsection{Deviant Burials in Settlements - General Remarks, Archaeological and Bioanthropological State of the Art}

As mentioned above, a particular feature of the Stillfried settlement is the finding of unburned human remains and animal depositions in abandoned storage pits - a phenomenon that originates in the Knovíz culture of north and northwest Bohemia (Bz D-Ha B) and its adjacent regions (Germany, Moravia). ${ }^{16}$ Stillfried's Late Bronze Age inhabitants obviously adopted this practice from these areas (especially Moravia and Bohemia). ${ }^{17}$ Corresponding hillfort sites with deviant burials in settlement pits are, for example, known from Brno-Obřany ${ }^{18}$ in Moravia and Gór-Kapolnadomb ${ }^{19}$ in western Hungary.

Characteristic for this practice are complete skeletons, displaced or partial human skeletons and single elements in conical storage pits. The bodily remains are placed on the base of these abandoned storage pits and rapidly covered by soil. The positions of the bodies are diverse, loose bent legs often prevailing. ${ }^{20}$ Some corpses may have been thrown into the cavities (e.g., such examples are also known from

15 Cavazzuti et al. 2019.

16 E.g. MüLler-Scheessel 2013. - Especially within the Late Knovíz Culture (Ha A, Ha A-B1): Wiesner 2009, 150-161 and list 24; 902-907. - STAPEL 1999, 393-409 (catalogue): 58 out of a total number of 228 documented Late Bronze Age settlement burials from 112 archaeological sites (= skeletal remains of 332 individuals) were associated with the Knovíz Culture, including two findings in central Germany: STAPEL 1999, 393, sites nos. 120 and 121 (catalogue). - Central German Lusatian Culture: BaLfanz, JARECKi 2004.

17 Stapel 1999, 218-219. - Griebl in prep.

18 ADÁMEK 1961, 213-214.

19 Ilon 1992. - Ilon 2001, 245-246. - Zoffmann 2001.

20 StAPel 1999, 410, footnote 1809. - Wiesner 2009, 150-151.
Stillfried Pit V1141) or seem to be bound by using cloths or ropes. ${ }^{21}$ Multiple burials outweigh individual burials. It has been shown that the number of incomplete skeletal remains increases with the number of individuals in a pit. Thus, it has been suggested that in such cases the decomposition process had happened elsewhere. This relates to children and adults of both sexes, whereby children and adolescents (3-18 years) predominate. ${ }^{22}$ Evidence of deadly violence exists, but for most individuals the cause of death is unknown. Aspects under discussion are the manner of death (diseases etc.), social status, origins or crisis situations and mass mortality. ${ }^{23}$ The human remains investigated here and in the previous study $^{24}$ were recovered from the two pits with multiple burials - containing a total number of seven individuals in V1141 and of 23 individuals in V841 - and a pit with a single skull V1133 (see detailed description below). Out of these 31 individuals, seven were previously studied by Maria Teschler-Nicola et al. ${ }^{25}$ and eleven individuals were selected for this study, which included overall eleven subadults, two adult males and three adult females (Tab. 1). Jewellery or traditional clothing accessories in conjunction with human remains are rare, whereas fragments of craft items, e.g., tools for textile and metalworking, grinding stones and ceramic vessels are typically found associated with them.

\subsubsection{Stillfried Settlement Pit V1141}

As mentioned above, Pit V114126 is located on the 'Kirchhügel', which is the name given to a conical-shaped elevation, where archaeologists assume the former residence of the Late Bronze Age leadership to have been (Fig. 1). ${ }^{27}$ The corpses of seven individuals were placed there, presumably within a short timeframe: a male, two females and four children (SK 1-7) ${ }^{28}$ (Figs. 2-3). Their sequential deposition was thoroughly documented: to the south, on an ash layer at the very bottom (sign. 9020), the corpses of an approx. 45-year-old female SK 5 (sign. 9027) and two children were deposited. Both children, the 7-8-year-old SK 4 (sign. 9026) and the 5-6-year-old SK 6 (sign. 9028) were identified as males based on their morphometric features. They were

\footnotetext{
21 STAPel 1999, 207.

22 Stapel 1999, 215 and Tab. 14. - Wiesner 2009, 902-907 and list 24. - GRIEBL, BIEDERER in prep.

23 Aspöck 2013, 31 with further literature.

24 Teschler-Nicola, Irrgeher, Prohaska 2016.

25 Teschler-Nicola, Irrgeher, Prohaska 2016.

26 Diameter at the bottom $2 \mathrm{~m}$; reconstr. depth $1.8-2 \mathrm{~m}$, reconstr. volume $3.6 \mathrm{~m}^{3}$.

27 In historical times the parish church was built exactly on this highest point of the landscape, see Figure 1.

28 Eibner 1980. - Hellerschmid 2015.
} 


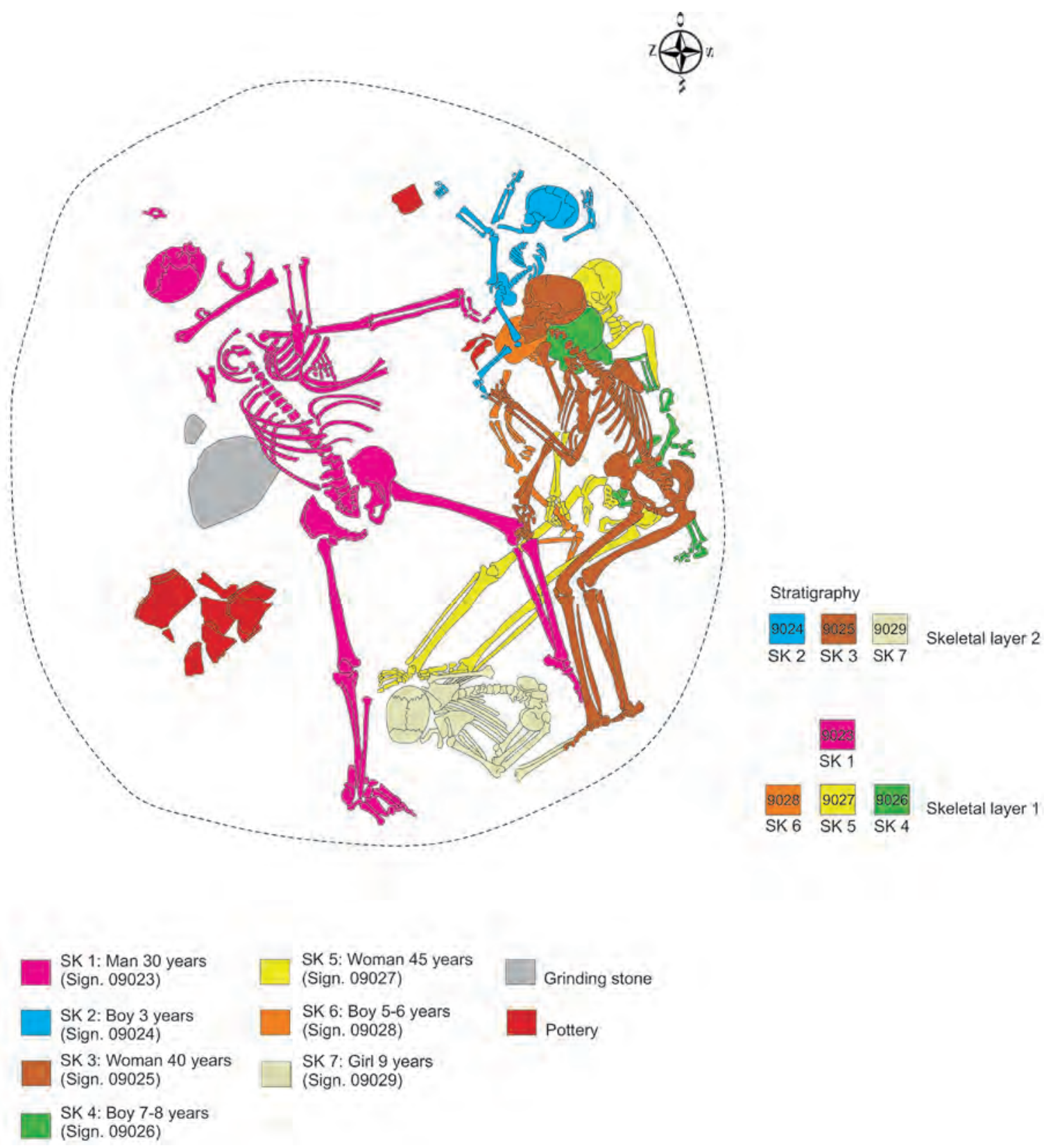

Fig. 2. Stillfried/March, Pit V1141. - Schematic representation of the seven skeletons deposited close to the bottom of the pit (after Szilvássy, Kritscher, Hauser 1988, Pl. 15, Fig. 47, processed by I. Hellerschmid and M. Griebl).

'set' on the female's lap (Fig. 4). Next, the adult, an approx. 30-year-old male SK 1 (sign. 9023) was placed in the centre of the pit (Figs. 3, 5). The setting was subsequently covered with loess (sign. 9021). The approx. 40-year-old female SK 3 (sign. 9025) was deposited in a right-sided flexed position in the next layer and the child SK 2, a 3-year-old boy (sign. 9024), was found close to her head. The position of the child's remains imply that its corpse was thrown down into the cavity. The 9-year-old subadult SK 7 (sign. 9029), a girl, lay crouched between the feet of SK 1; her head was placed on an unusually large and barely burned loom weight. The pit was filled with loess (layer 9030) and ash (layer 9031) (Fig. 6). Emil Breitinger ${ }^{29}$ examined these skeletal remains intensively; his report focused on age at death estimation and sex diagnosis, identification and documentation of pathological alterations, genetically determined traits ('genetic markers') as well as peristatic-functional features. It is an excellent example of bioanthropological research of the

29 BREITINGer 1980. 


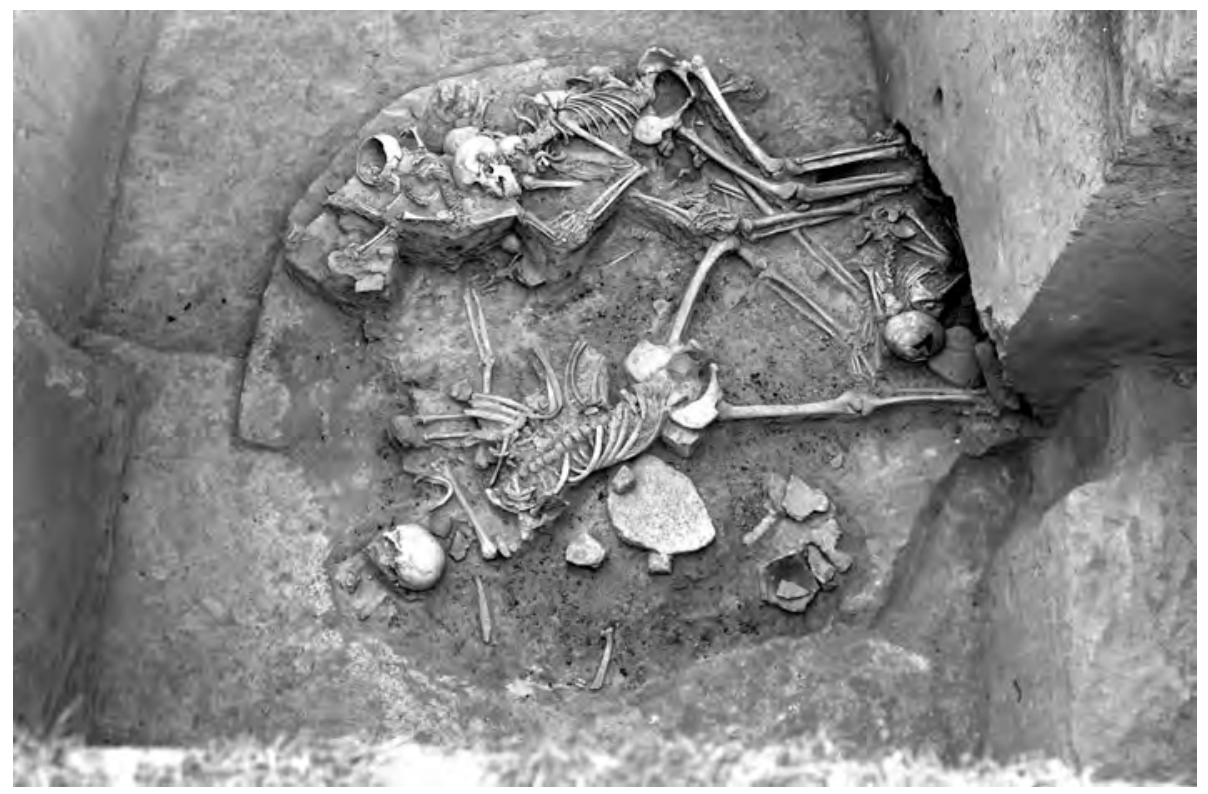

Fig. 3. Stillfried/March, Pit V1141. - Photo taken during the excavation (Documentation of the excavation of Stillfried, Niederösterreichische Landessammlung für Ur- und Frühgeschichte, photo no. ST 28389).

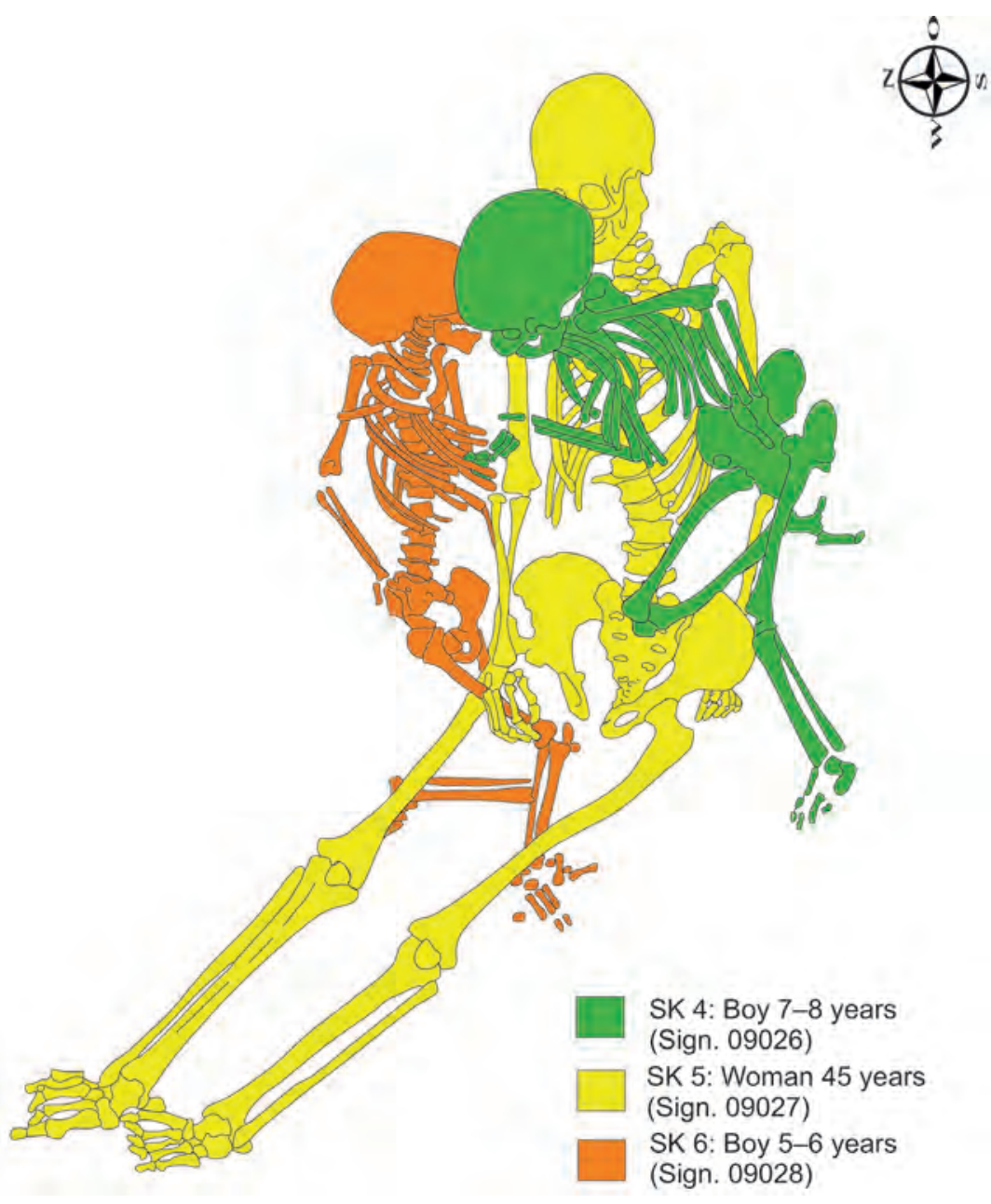

Fig. 4. Stillfried/March, Pit V1141. - Schematic representation of the three skeletons from the lower position in the pit, SK 4, 5 and 6 (after SZILVÁssy, Kritscher, Hauser 1988, Pl. 16, Fig. 48, processed by I. Hellerschmid and M. Griebl). 


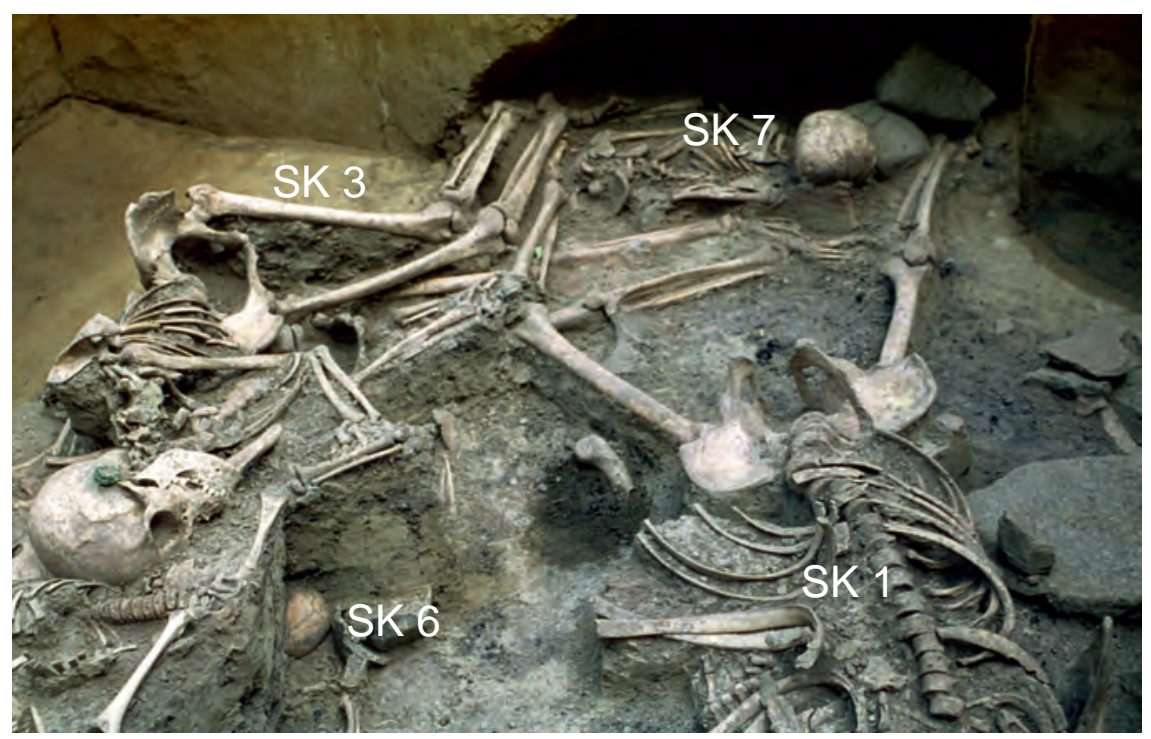

Fig. 5. Stillfried/March, Pit V1141. - Detail of the southwestern part of the deposition: in the middle one can see the left leg of the man SK 1, which is touching the right lower leg of the woman SK 3 and overlays the legs of woman SK 5. The right hand of SK 3 lies above the man's knee but without any physical contact. Between the man's feet one can see SK 7. Under SK 3 the skull of child SK 6 comes to light under the loess layer sign. 9021, which is very thick in this area (Documentation of the excavation of Stillfried, Niederösterreichische Landessammlung für Urund Frühgeschichte, photo no. ST001473).

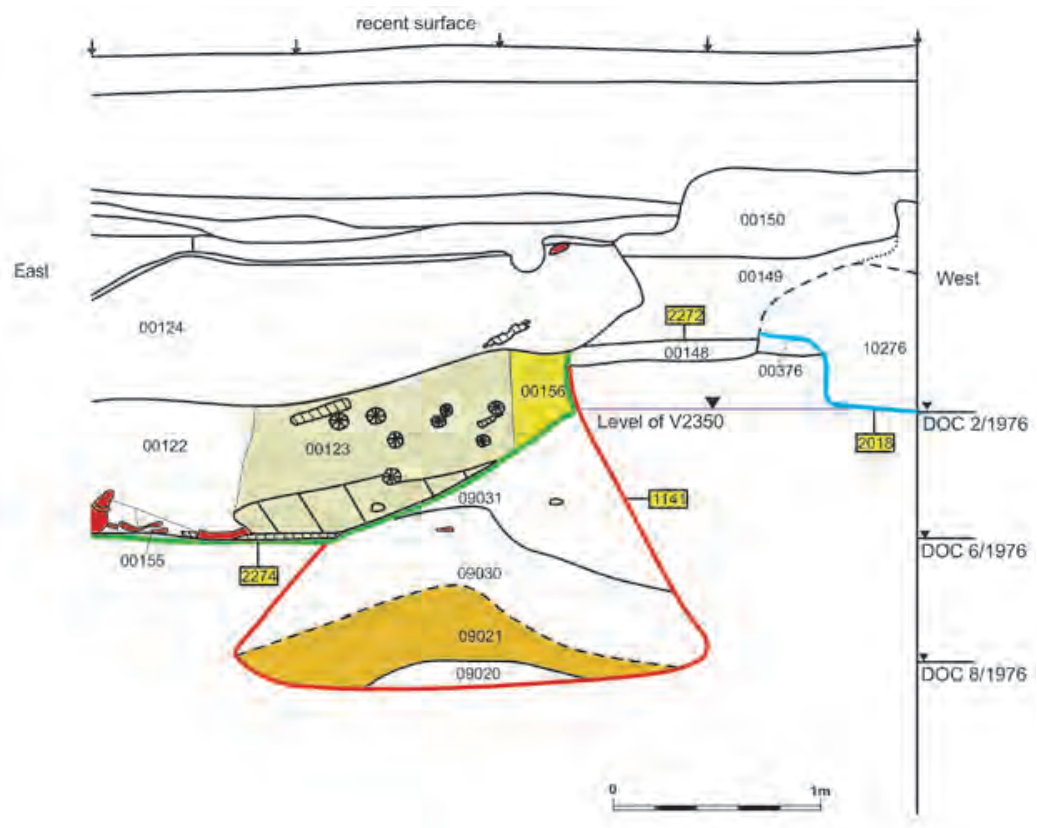

Charred construction (wood, clay), (Sign. 00123)

"Wooden wall" (Sign. 00156)

Pottery

Fig. 6. Stillfried/March, Pit V1141. - South profile of V1141 and the (wooden) construction V2274, which cuts into V1141 in the upper area. The level of the flat object V2350 with a human skull is also shown (proAnimal bone cessed by I. Hellerschmid, S. Tikatsch and M. Griebl). 
1980s. Nevertheless, it is possible that he has overlooked some symptoms of malnutrition (e.g., inflammatory changes at the alveolar rims caused by vitamin $\mathrm{C}$ deficiency) that are evident in the associated tables. Thus, we assume that a systematic palaeopathological re-investigation of the seven individuals recovered from Pit V1141 could presumably enhance our understanding and interpretation of non-normative burials and their complex, interrelated causes at Stillfried.

The remains of the seven individuals were investigated for the first time for $n\left({ }^{87} \mathrm{Sr}\right) / n\left({ }^{86} \mathrm{Sr}\right)$ isotopic composition in enamel and dentine by Teschler-Nicola et al. along with some environmental samples from Stillfried/March. ${ }^{30}$ The isotope ratios varied considerably. The ratios determined for SK 5 (the 45-year-old female), SK 1 (the 30-year-old male) and the two children SK 6 (the 5-6-year-old boy) and SK 7 (the 9-year-old female) are above the range that characterizes the local Stillfried environment. Hence, we have a well-founded argument that these four individuals most likely spent their early childhood outside Stillfried (Tab. 1) ${ }^{31}$ In contrast, the $n\left({ }^{87} \mathrm{Sr}\right) / n\left({ }^{86} \mathrm{Sr}\right)$ ratios of the enamel of the three individuals SK 2 (the 3-year-old boy), SK 3 (the approx. 40-year-old female) and SK 4 (the 7-8-year-old boy) match the local signal from Stillfried/March (Tab. 1), according to which these individuals presumably grew up in or in the immediate vicinity of the central settlement of Stillfried.

Further research questions concerned the reconstruction of a genealogical pedigree of the seven individuals buried in Pit V1141. Morphological similarity/dissimilarity resulted in two models. ${ }^{32}$ In 2018, mitochondrial (mt)DNA was applied to resolve the matrilineal relationship - with a surprising result: a maternal relationship was detected only in one case (SK 5, the approx. 45-year-old woman and SK 6, the 5-6-year-old boy). ${ }^{33}$

\subsubsection{Stillfried Settlement Pit V1133}

Out of the pear-shaped Pit V1133 located at the inner rim of the rampart a child's calvarium was recovered (Fig. 7). It exhibits several perimortally caused ovoid/circular buttonhole fractures, some associated with burst fractures,

30 Teschler-Nicola, Irrgeher, Prohaska 2016, 165 and Fig. 5. 31 All four values are higher than the signal of the environment at Stillfried, with the values for the two children (SK 6, SK 7) being higher than the values for the adults (SK 1, SK 5). - Teschler-NicolA, Irrgeher, Prohaska 2016, 165 and Fig. 5.

32 With mismatched results, BREITINGER 1980, 88 and Fig. 4. - SzILvásSy, KRITSCHER, HAuser 1988, 70.

33 Parson et al. 2018, Fig. 2.

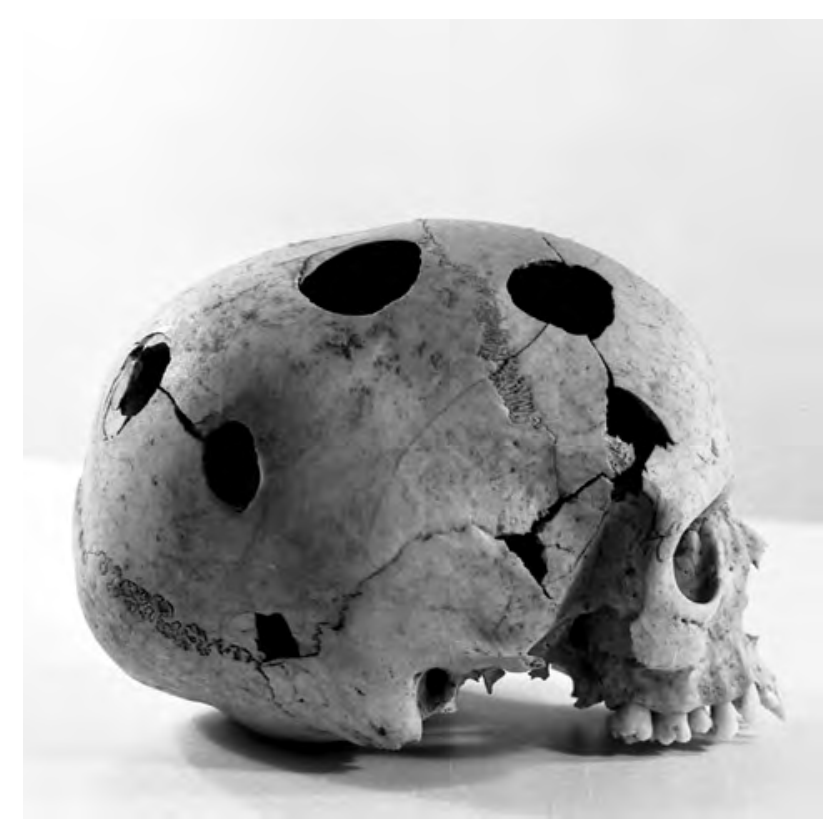

Fig. 7. Stillfried/March, Pit V1133. - The stroke-pierced calvarium of a 12 to 13-year-old - obviously female - individual (Documentation of the excavation of Stillfried, Niederösterreichische Landessammlung für Ur- und Frühgeschichte, photo no. 120308_29727).

resulting from a violent attack. ${ }^{34}$ Moreover, the child's remains show some serious inflammations..$^{35}$ Among other remarkable findings from this pit, a pure barley glume $\mathrm{ash}^{36}$ and the carcass of a maltreated young female dog are worth mentioning. ${ }^{37}$

\subsubsection{Stillfried Settlement Pit V841}

In the deep Pit V841 ${ }^{38}$ the remains of 23 individuals were deposited within at least four subsequent deposition processes (Figs. 8-9). ${ }^{39}$ Each of these four corpse layers was covered with soil.

The lowest skeletal layer of V841 (skeletal layer 1) consisted of the complete skeletons of a woman

34 Seven artificial holes in the right half of the skull. - BREITINGER 1976, 95-98. - Eibner 1976. - Griebl, Hellerschmid 2013, 331332. - Wiltschke-Schrotta, Marschler in prep. (catalogue).

35 Evidence of an inflammatory haemorrhagic process located in the skull's endocranial layer, which indicates a disease, e.g. meningitis or meningoencephalitis, additional evidence of enamel hypoplasia, which is to be interpreted as the result of malnutrition or a serious infectious disease in early childhood: WiLTSCHKE-SCHROTTA, MARSCHLER, in prep. (catalogue).

36 SAuter, Wurst, Hoke 1976.

37 Eibner 1976.

38 Depth $3 \mathrm{~m}$, max. diameter at the bottom $3.50 \mathrm{~m}$, volume $19 \mathrm{~m}^{3}$. 39 WiltschKe-Schrotta 2006. - Griebl, Hellerschmid 2013, 334-340. - Griebl in prep. - Hellerschmid, Griebl in prep. 


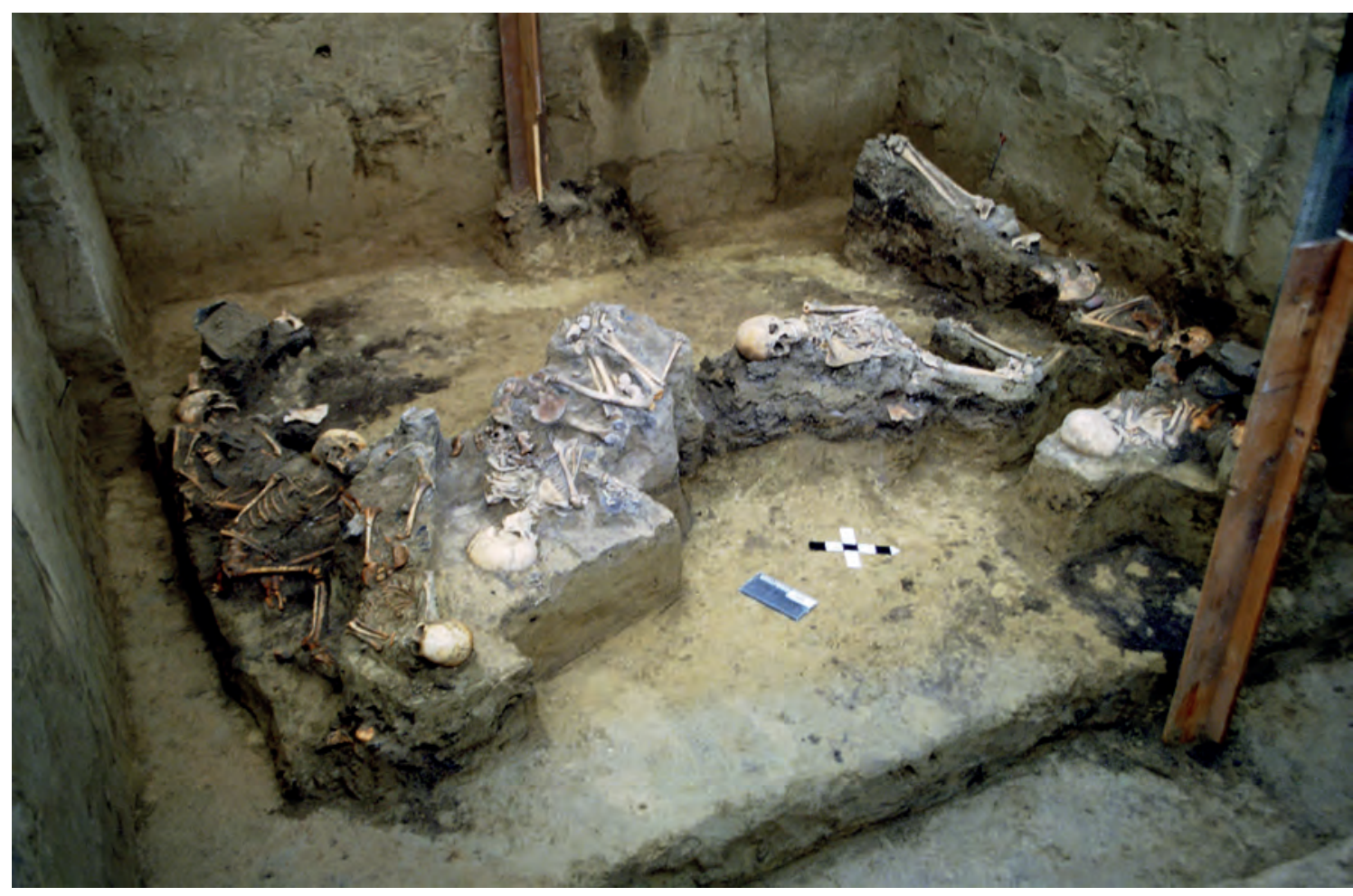

Fig. 8. Stillfried/March, Pit V841. - Photo taken during the excavation. Clearly recognizable and remarkable is the great depth of the pit. The reconstructed pit depth is $3.70 \mathrm{~m}$, the reconstructed diameter at the bottom $3.80 \mathrm{~m}$ (Documentation of the excavation of Stillfried, Niederösterreichische Landessammlung für Ur- und Frühgeschichte, photo no. 3597).

(SK 13/sign. 9054) and two children (SK 11/sign. 9052, 12/sign. 9053). The corpses were placed along the pit wall, facing each other. Skeletal layer 2 contained the remains of five individuals, including three children (SK 9/sign. 9050, 10/sign. 9051, 15/sign. 9056), a teenager (SK 8/sign. 9049) and a female (SK 14/sign. 9055), whose body positions vary widely. The skulls of all individuals pointed south or southeast. The body positions ranged from almost stretched $(\mathrm{SK} 8,10)$ to flexed (SK 9) and even extremely contracted legs, which suggests fetters (SK 14). From child SK 15 only the upper part of the body was preserved, and child SK 10 (characterized by a striking small skull) had been covered with ceramic shards. Skeleton layer 3 included two almost complete human bodies (SK 4/sign. 9044, 7/sign. 9048) and the remains of four individuals (SK 3/sign. 9043, 5/1/sign. $9045,5 / 2 /$ sign. 9046 and 6/sign. 9047) in various degrees of decomposition and completeness. Most of the skeletons from this layer show bite marks, which suggests a different place of decomposition where carnivores could approach the corpses. ${ }^{40}$ The twisted body posture and position of the extremities of SK 7 (female, 15-19 years) most likely indicate fetters on the arms and legs. Then a hot layer of ash (layer 363) followed, in which two individuals were possibly plunged: a mature male who still had his accessory bag on his belt (SK 1/sign. 9041) and a child (SK 2/sign. 9042). Their bones were affected by the heat. Finally, the badly burned but already calcified pieces of bones from at least seven individuals (SK 16-22) were found in this ash layer.

Filling took place quickly because there are no traces of sedimentation. Therefore, the pit must have been covered in between; probably with a wooden lid (Fig. 10). A cavity remained after the last filling until the covering collapsed. This leads to the conclusion that all manipulations of the human bodies took place outside the deep pit. Even animals were only able to reach the corpses outside the pit (to a very limited extent).

It has been ascertained that the individuals from Pit V841 (and V1133) were more frequently affected by inflammations located at the skull's endocranial layer and other skeletal elements than the individuals recovered from

40 SK 4, 5/1, 5/2, 6, 7: Wiltschke-Schrotta, Marschler in prep. (table). 


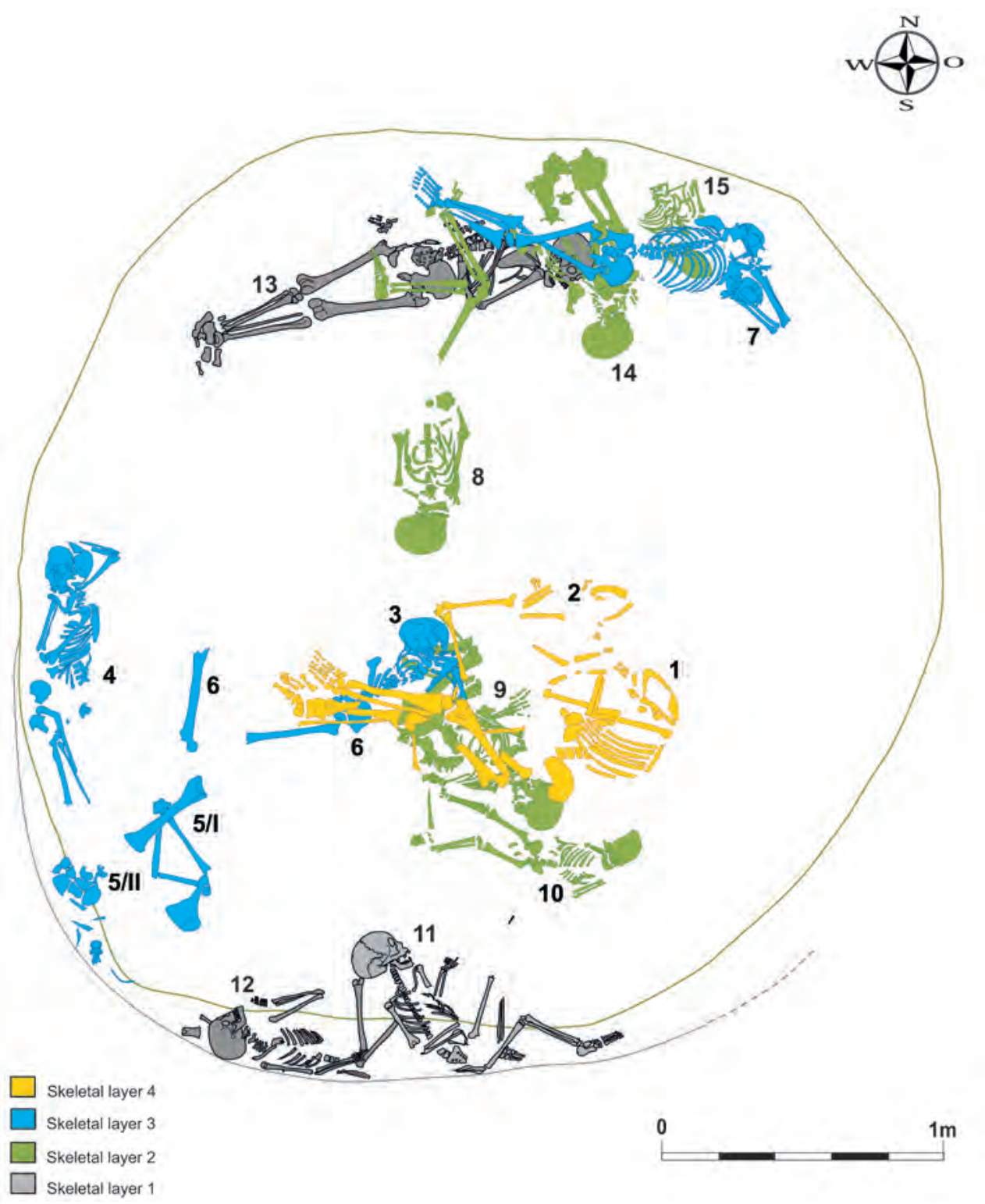

Fig. 9. Stillfried/March, Pit V841. - Schematic presentation of the four skeletal layers of Pit V841 with a total of sixteen unburned human skeletons or skeletal parts (SK 1-4, 5-1, 5-2, 6-15). Also, badly burned but already calcined pieces of bones from at least seven individuals (SK 16-22) were found within skeletal layer 4, but are not shown here (processed by I. Hellerschmid and S. Tikatsch).

Pit V1141. ${ }^{41}$ Some features are already healed. Tooth decay is barely detectable in the individuals from Pit $\mathrm{V} 841,{ }^{42}$ whereas enamel hypoplasia gives some indications for a deficiency

41 Wiltschke-Schrotta, Marschler in prep. (text and catalogue): Cribra orbitalia: V841:SK 2, 8, 13?, 14, 15; V1141: SK 6 (slight expression), SK 7; perhaps SK 2 (BREITINGER 1980, 73); meningitis/ meningoencephalitis: V841: SK 2(?), 3, 4(?), 5-2, 8, 10,11(?), 12(?), 15 and the skull from Pit V1133; sinusitis: V841: SK 7; V1133; perisinusitis: V841: SK 15; striae: V841: SK 1, 2, 5, 6, 8, 9, 11-14, 16, 17, 21. 42 Only SK 14 (V841): WiltschKe-SchrotTA, Marschler in prep. (catalogue). disease. ${ }^{43}$ By contrast, as mentioned above, the skeletons from Pit V1141 seem to be less affected by pathological traces: ${ }^{44}$ only carious lesions were observed ${ }^{45}$ Nevertheless,

43 Enamel hypoplasia: V841: SK 1, 2, 7 (slight expression), 8, 9, 11 and 12 (slight expression), 14; V1133.

4437 examples of evidence of inflammation in 16 individuals from V841, whereas only two cases in V1141 are documented: Wiltschke-Schrotta, Marschler in prep. (catalogue).

45 Due to caries, the first molar (right, upper jaw) of the elderly woman SK 5 is destroyed completely: WiLTSCHKE-SCHROTTA, MARSCHLER in prep. (text and catalogue). 


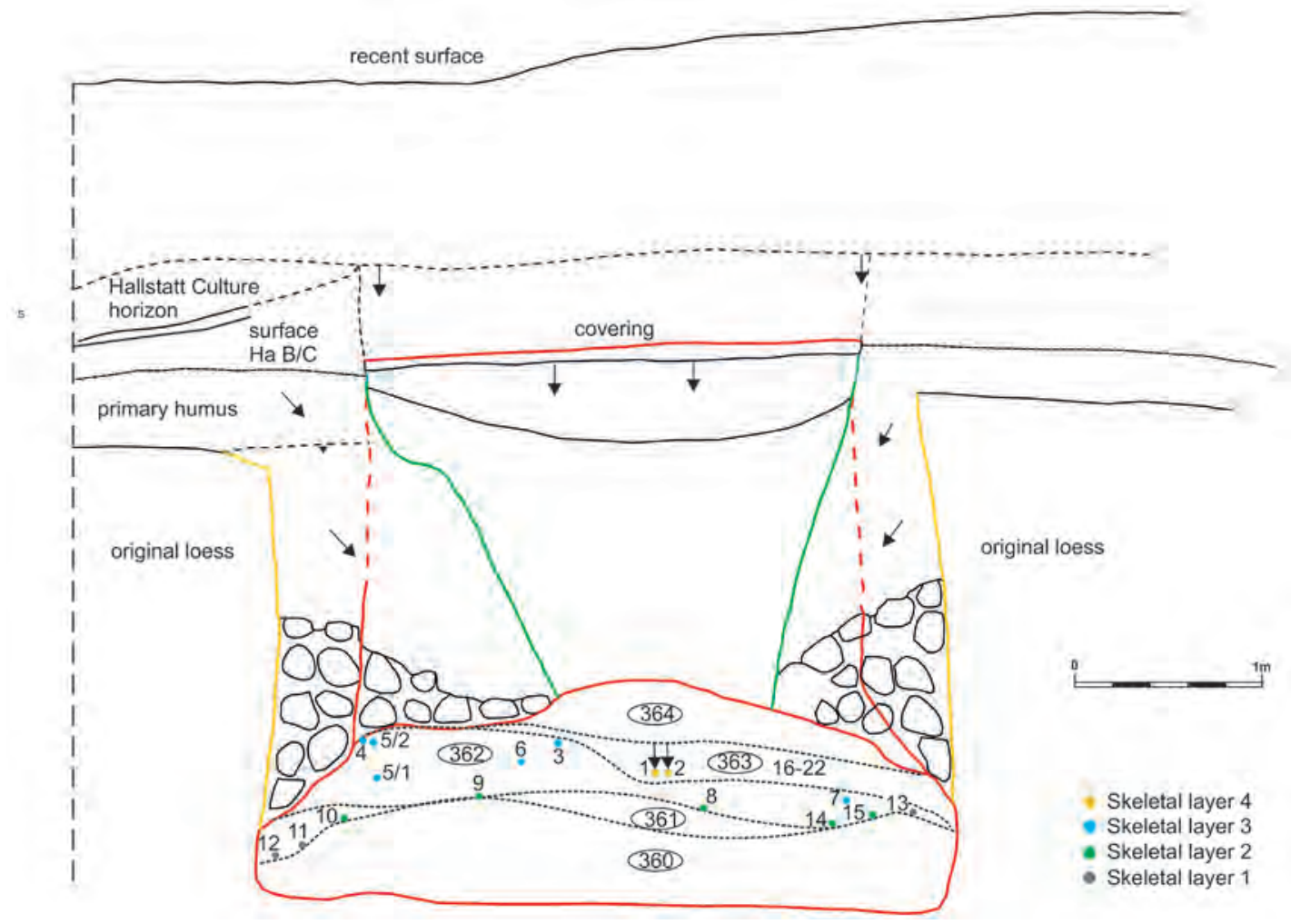

Fig. 10. Stillfried/March, Pit V841. - The schematic overall profile shows the different filling layers in the lower area of the pit with sixteen unburned human skeletons or skeletal parts (SK 1-4, 5-1, 5-2, 6-15) and the approximate location of the burned remains of at least seven individuals (SK 16-22). - Red: Original pit edge. - Green: Secondary filling funnel of the cavity. - Yellow: Secondary break edge (processed by I. Hellerschmid and M. Griebl).

it must be mentioned here that Breitinger's recording system is not consistent with the one used in the recent study, a fact that limits the possible level of reliability, at least with regard to symptoms of malnutrition.

\subsection{Sr Isotope Ratio Analysis and Diagenetic Changes}

\subsubsection{State of the Art}

Sr isotope ratio analysis of human skeletal remains has been used widely to answer questions of provenance and migration. ${ }^{46}$ The main interest lies in the radiogenic $n\left({ }^{87} \mathrm{Sr}\right) / n\left({ }^{86} \mathrm{Sr}\right)$ ratio (commonly also noted as ${ }^{87} \mathrm{Sr} /{ }^{86} \mathrm{Sr}$ ratio), ${ }^{47}$ which varies according to the radioactive decay of ${ }^{87} \mathrm{Rb}$ to ${ }^{87} \mathrm{Sr}$ (half-life $\sim 48.8 \times 10^{9}$ years) and is therefore a function of the geologi$\mathrm{cal}$ age and the original $\mathrm{Rb} / \mathrm{Sr}$ ratio of the bedrock material. ${ }^{48}$

46 As comprehensively described in recent reviews: BENTLEY 2006. Slovak, Paytan 2012.-Szostek, Mądrzyk, Cienkosz-Stepańczak 2015. - Sehrawat, Kaur 2017.

47 The isotopic composition is reported in this manuscript as isotope-amount ratios $\left(n\left({ }^{87} \mathrm{Sr}\right) / n\left({ }^{86} \mathrm{Sr}\right)\right)$, which is the correct notation according to IUPAC guidelines: CopLen 2011. In the following text, the $n\left({ }^{87} \mathrm{Sr}\right) / n\left({ }^{86} \mathrm{Sr}\right)$ ratios are also referred to as $\mathrm{Sr}$ isotope ratios.

48 Capo, Stewart, Chadwick 1998.
Sr is mobilized from geological material by weathering and transferred into soil, water and further incorporated into plants. Finally, the radiogenic Sr signature is taken up without substantial fractionation ${ }^{49}$ by animals and humans through the food chain and stored in Ca-rich matrices (such as bones and teeth ${ }^{50}$ ) due to the chemical similarity of $\mathrm{Sr}$ and $\mathrm{Ca}$. The incorporated $\mathrm{Sr}$ isotopic signature reflects the ratio of a geographic location inhabited during a specific period of an individual's life, depending on the type of tissue, its specific turnover and diet. ${ }^{51}$ Human enamel is of primary interest in migration studies. Enamel stores $\mathrm{Sr}$ only during tooth-formation (varying between teeth ${ }^{52}$ ) and therefore preserves information about the place of residence of an individual during their childhood ${ }^{53}$ ('archive of the

49 Capo, Stewart, Chadwick 1998. - Blum et al. 2000.

50 Price, Grupe, Schroter 1998. - Bentley 2006.

51 Capo, Stewart, Chadwick 1998. - Bentley 2006.

52 Hillson 1996 - AlQahtani, Hector, Liversidge 2010.

53 For example, the incremental growth of human first premolar (Hillson P3 after Hillson 1996) enamel (used in this study) starts and continues until completion between 2.5 and 6.5 years of age: AlQahtani, Hector, Liversidge 2010. 
childhood $\left.{ }^{54}\right)$. The comparison of the Sr isotopic signature in enamel with the autochthonous $\mathrm{Sr}$ isotopic composition of the habitat of interest (the place where an individual was buried) can give an indication of an individual's possible autochthonous (local) or allochthonous (non-local) origins and, thus, enable us to reconstruct a possible change of residence. ${ }^{55}$ The general approach is based on the comparison of the $\mathrm{Sr}$ isotope signature to an isoscape $\mathrm{e}^{56}$ (= composition derived from isotope and landscape) providing the spatial distribution of the local environmental Sr isotopic composition of bioavailable Sr. A more refined procedure considers dietary sources of $\mathrm{Sr}$ provided by food and beverages ${ }^{57}$ in addition to the chemical fingerprint of the habitat.

Human dentine, on the other hand, is a living tissue ${ }^{58}$ and re-equilibrates in accordance with an individual's metabolism due to its intimate intergrowth with capillary veins. ${ }^{59}$ The majority of the compartment forms the primary dentine, which is secreted before apical closure of the tooth root. ${ }^{60} \mathrm{In}$ addition, a thin layer of secondary dentine forms after the complete formation of the tooth around the pulp chamber. ${ }^{61}$ Tertiary dentine forms as a response to damage to the tooth (e.g., caries or severe abrasion). ${ }^{62}$ Although primary dentine, once formed during adolescence and early adulthood, does not remodel and undergo significant metabolic or structural changes, its odontoblasts lining the pulp chamber retain the ability to produce new dentine throughout life. ${ }^{63}$ In this respect, similarly to human enamel, it is expected that human primary dentine preserves Sr isotopic information about the place of residence of an individual during certain time spans of their adolescence/early adulthood, which varies between teeth. ${ }^{64}$ When compared to the $\mathrm{Sr}$ isotopic signatures of its enamel and the habitat under investigation, the primary dentine might give additional information about the timing of a change in the Sr source and thus a possible change of residence.

\footnotetext{
54 Grupe 1998 .

55 Lee-Thorp, Sponheimer 2003. - Slovak, Paytan 2012. - Lewis, Coath, Pike 2014. - Szostek, Mądrzyk, Cienkosz-Stepańczak 2015.

56 Evans et al. 2010. - Bataille, Bowen 2012. - Maurer et al. 2012.

- Zitek et al. 2015. - KootKer et al. 2016.

57 Evans et al. 2010. - Bataille, Bowen 2012. - Maurer et al. 2012.

- Zitek et al. 2015. - KoOtKer et al. 2016.

58 ForTes et al. 2015.

59 Fergusson, Purchase 1987. - Chiaradia, Gallay, Todt 2003.

60 Arana-Chavez, Massa 2004.

61 Shepherd et al. 2012.

62 Beaumont et al. 2015.

63 NANCI 2013.

64 Hillson 1996. - AlQahtani, Hector, Liversidge 2010.
}

\subsubsection{Diagenetic Alterations of $\mathrm{Sr}$ - the Potential of (Primary)} Dentine for the Evaluation of Biogenic Sr Isotopic Signature

The post-depositional overprint of the Sr isotopic signatures incorporated in ancient skeletal remains by cumulative physical, chemical and biological alteration in the form of inorganic modifications and structural alterations - referred to as diagenesis - is a challenge in the application of Sr isotope ratio analysis and the interpretation of its results. ${ }^{65}$ Buried bodily remains may absorb (diagenetic) Sr from repository material (soil, groundwater) and accumulate it, primarily in bones and teeth, by processes of recrystallization of the hydroxyapatite lattice, adsorption onto the apatite crystal surface or crystallization of secondary minerals (e.g., brushite $\left(\mathrm{CaHPO}_{4} \cdot 2 \mathrm{H}_{2} \mathrm{O}\right)$ or carbonate $\left.\left(\mathrm{CaCO}_{3}\right)\right)$ in micro-cracks, pores and vacancies. ${ }^{66}$ This effect changes the Sr fingerprint incorporated in vivo (often referred to as biogenic $\mathrm{Sr}$ ).

Hence, one must consider diagenetic phenomena in elemental or isotopic analyses of ancient skeletal remains and/ or teeth. In population studies, the correlation of the Sr mass fraction $w(\mathrm{Sr})$ and the $n\left({ }^{87} \mathrm{Sr}\right) / n\left({ }^{86} \mathrm{Sr}\right)$ isotope amount ratios in bone/teeth in combination with the chemical information of the burial environment has been applied as a useful tool to assess a potential diagenetic impact. ${ }^{67}$ Further indicators for post mortem alterations are elevated $w(\mathrm{Ca}) / w(\mathrm{P})$ mass fraction ratios above the theoretical value of biogenic hydroxyapatite of (2.16). ${ }^{68}$ Elevated levels of transition elements like $\mathrm{Al}, \mathrm{Si}$ and $\mathrm{Ba}$ (in vivo $<10 \mu \mathrm{g} \mathrm{g}^{-1}$ to $100 \mu \mathrm{g} \mathrm{g}^{-1}$ ), elevated contents of $\mathrm{V}, \mathrm{Fe}$ and $\mathrm{Mn}$, and/or the presence of elevated mass fractions of (ultra-)trace elements (mainly REE, $\mathrm{Y}, \mathrm{Hf}, \mathrm{Th}, \mathrm{U}$, which show an in vivo content $\left.<1 \mu \mathrm{g} \mathrm{g}^{-1}\right)^{69}$ may also be a sign of contamination. The degree of damage depends on the depositional conditions (soil, water, acidity, microorganisms, etc.) and is therefore matrix-dependent and site-specific. ${ }^{70}$

The idea that enamel does not undergo significant diagenetic alteration due to its extremely compact structure with very small pores and minor amount of organic content $(\sim 2 \%)$ and that it, thus, represents a reliable matrix for mobility and migration studies is more or less generally

65 Wilson, Pollard 2002.

66 Nelson et al. 1986. - Kohn, Schoeninger, Barker 1999. Nielsen-Marsh, Hedges 2000. - Prohaska et al. 2002. - Hoppe, Koch, Furutani 2003.

67 Hoppe, Koch, Furutani 2003. - Copeland et al. 2010.

68 Sillen 1986.

69 Kohn, Schoeninger, Barker 1999. - Trueman et al. 2008. Koenig, Rogers, Trueman 2009. - Kohn, Moses 2013. - Benson et al. 2013. - Willmes et al. 2016. - KAMENOv et al. 2018.

70 Sponheimer, LeE-Thorp 2006. - Dudás et al. 2016. 
accepted. ${ }^{11}$ Nonetheless, enamel is not immune to diagenetic alterations. ${ }^{72}$ Signals of diagenetic modification can be identified by comparing the $\mathrm{Sr}$ mass fraction content in enamel and published values and modern biogenic Sr content mass fraction ranges: it is indicated by elevated $\left(>250 \mu \mathrm{g} \mathrm{g}^{-1}\right)$ or depleted $\left(<100 \mu \mathrm{g} \mathrm{g}^{-1}\right)$ Sr mass fractions. ${ }^{73}$ Dentine and bone as 'living tissue', ${ }^{74}$ on the other hand, are characterized by higher porosity, smaller crystallites and a higher organic content $(\sim 30 \%)$. Therefore, these compartments are more prone to diagenetic changes. ${ }^{75}$ This effect is well known and used to provide an indication of the $n\left({ }^{87} \mathrm{Sr}\right) / n\left({ }^{86} \mathrm{Sr}\right)$ ratio of the burial environment, which has been used in a number of studies to estimate the bioavailable $n\left({ }^{87} \mathrm{Sr}\right) / n\left({ }^{86} \mathrm{Sr}\right)$ ratio at a particular location. ${ }^{76}$ However, the use of bone and dentine in migration studies of past populations is under discussion. Most studies categorically exclude these tissues from the interpretations, if diagenetic alterations have been identified. Only a limited number of publications deal with this issue of biogenic Sr isotope preservation in human/animal bone and (primary) dentine and diagenetic proportions of $\mathrm{Sr} .{ }^{77} \mathrm{To}$ estimate the biogenic Sr isotopic signature in diagenetically altered (primary) dentine, one can use chemical/mechanical (e.g., sequential leaching ${ }^{78}$ ) and mathematical approaches (based on the diagenetic Sr proportion and the Sr isotopic signature of the repository material). ${ }^{79}$ The present study deals with this particular methodological subject by proposing an improved mathematical correction.

\section{Samples and Methods}

\subsection{Samples}

The samples for the $\left.n\left({ }^{87} \mathrm{Sr}\right) / n{ }^{86} \mathrm{Sr}\right)$ ratio analysis were provided by the Austrian Academy of Sciences and the Natural History Museum Vienna. Eleven individuals from the Late Urnfield Culture deposited in three different pits (V841,

71 Kyle 1986. - Bentley 2006. - Montgomery 2010. - SlovaK, Paytan 2012. - Szostek, Mądrzyk, Cienkosz-Stepańczak 2015.

72 Kohn, Schoeninger, Barker 1999. - Lee-Thorp, Sponheimer 2003. - Dauphin, Williams 2004. - Sponheimer, LeE-Thorp 2006. - DudÁs et al. 2016.

73 DudÁs et al. 2016.

74 Fortes et al. 2015.

75 Driessens, VerbeECK 1990.

76 Grupe et al. 1997. - Budd et al. 2000. - Price, Burton, Bentley 2002. - Schweissing, Grupe 2003. - Price et al. 2004. - Bentley, Knipper 2005. - Irrgeher et al. 2012. - KNipper et al. 2012. - MAURER et al. 2012.

77 Budd et al. 2000. - LeE-Thorp, Sponheimer 2003. - Copeland et al. 2010.

78 Sillen 1986.

79 Budd et al. 2000. - Copeland et al. 2010. - Kreutz 2011. - RetZMANN et al. 2019.
V1133 and V1141) were selected: 8 of the 23 individuals from the large Pit V841 were sampled, whereby each of the four skeletal layers was considered. Furthermore, and as mentioned above, we included the isolated calvarium of the child from Pit V1133. Lastly, we selected and re-investigated two of the seven individuals deposited in Pit V1141 to ensure comparability to the study of Teschler-Nicola et al..$^{80}$ By preference, the first premolars were taken; ${ }^{81}$ in one case a second premolar ${ }^{82}$ and in another case a deciduous canine $e^{83}$ were analysed instead (Tab. 1).

Animal teeth, mussel shells, plant (straw, wood), recent water and recent soil samples from the Late Urnfield Culture were used to determine and verify the local and autochthonous $n\left({ }^{87} \mathrm{Sr}\right) / n\left({ }^{86} \mathrm{Sr}\right)$ ratio range. The local environmental range was determined by recent soil and water (in duplicates) samples that were taken in a diameter of about five kilometres around the site, based on the assumed maximum area that could be reached on foot (Tab. 3). ${ }^{84}$ The autochthonous $n\left({ }^{87} \mathrm{Sr}\right) / n\left({ }^{86} \mathrm{Sr}\right)$ ratio of the hillfort site at Stillfried/ March was identified by the faunal remains of species, e.g., the wild boar and domesticated animals such as dogs, prehistoric plant remains and prehistoric mussel shells (Tab. 2).

\subsection{Methods}

\subsubsection{Technical Procedures}

Sample preparation, analysis and evaluation took place at the VIRIS Laboratory (University of Natural Resources and Life Sciences, Vienna). The procedure of sample cleaning followed standard protocols. ${ }^{85}$

The human teeth were cut vertically in half from the crown to the root using a low speed saw (IsoMet, Buehler, Lake Bluff, IL, USA) with a diamond blade for sampling circumpulpal primary dentine. The surface and the pulp cavity of teeth and mussel shells were pre-cleaned using an electric drill (Dremel Moto-Tool, Wisconsin, USA) combined with $100 \mu \mathrm{m}$ diamond drilling heads. ${ }^{86}$ Approximately 10-20 mg of enamel and dentine from animal and human individuals

80 Teschler-Nicola, Irrgeher, Prohaska 2016.

81 The incremental growth of human first premolar (Hillson P3) enamel starts and continues until completion between 2.5 and 6.5 years of age: AlQAHTAni, Hector, Liversidge 2010.

82 The incremental growth of human second premolar (Hillson P4) enamel starts and continues until completion between 3.5 and 7.5 years of age: AlQAhtani, Hector, Liversidge 2010.

83 The incremental growth of human deciduous canine enamel starts in-utero and continues until completion at 7.5 months of age: ALQAhtani, Hector, Liversidge 2010.

84 Kohler-Schneider 2001.

85 IRRgEHER et al. 2012.

86 It is assumed that the thin layer of secondary dentine is completely removed by this pre-cleaning. 
as well as the mussel shells were sampled using an electric drill (Dremel). The sampled powders were mixed with $2 \mathrm{ml}$ double sub-boiled concentrated nitric acid ( $w=65 \%$, further purified from nitric acid p.a., Merck, Darmstadt, Germany) and $1 \mathrm{ml}(w=30 \%)$ hydrogen peroxide (Merck). The samples were digested on a hot plate at $150^{\circ} \mathrm{C}$ for 2.5 hours. Afterwards nitric $\left(c=8 \mathrm{~mol} \mathrm{~L}^{-1}\right)$ acid, which was prepared from double sub-boiled concentrated nitric acid $(w=65 \%)$, was added until a total weight of approximately $10 \mathrm{~g}$ was achieved. The mobile $\mathrm{Sr}$ fraction of soil was extracted using ammonium nitrate following the protocol DIN ISO 19730 (1997) to retrieve the bioavailable Sr fractions. ${ }^{87}$ The water samples were filtered and acidified to $w=2 \%$. Digestion of the archaeological wood and straw samples was accomplished by microwave assisted digestion using double subboiled concentrated nitric acid ( $w=65 \%)$ and hydrogen peroxide $(w=30 \%)$.

Prior to Sr isotopic analysis, Sr was separated from interfering matrix elements (mainly $\mathrm{Ca}, \mathrm{Rb}$ and $\mathrm{P}$ ). The digested teeth, mussels and prehistoric wood and straw samples were manually separated following the standard protocol. ${ }^{88}$ The extracted soil and acidified water samples were automatically separated (Sr-matrix separation) using a prepFAST-MC (ESI, Omaha, US) according to a standard protocol..$^{89} \mathrm{By}$ using an ICP-MS (NexION 350D, PerkinElmer, Waltham, MA, US), we performed a multi-elemental analysis and screenings following a standard protocol..$^{90}$

A multi collector ICP-MS (Nu Instruments Ltd., Wrexham, UK) was used for the assessment of the $n\left({ }^{(78} \mathrm{Sr}\right) / n\left({ }^{86} \mathrm{Sr}\right)$ ratios. Separated samples were diluted with nitric acid $(w=$ $2 \%$ ) to achieve a mass fraction of $\beta=50 \mathrm{ng} \mathrm{g}^{-1}$. A solution of NIST SRM 987 (NIST Gaithersburg, USA) was used as an isotopic reference for standard-sample bracketing (SSB). Diluted samples and NIST SRM 987 solution were doped with $\mathrm{Zr}$ (Merck-Millipore) to allow for internal inter-elemental instrumental isotopic fractionation correction. ${ }^{91}$ Mass fractions of samples and SSB standards were matched within $10 \%$. A detailed description of the instrument configuration, data collection, blank correction and measurement strategy can be found elsewhere. ${ }^{22}$ The results were evaluated, and the measurement uncertainty was calculated using a Microsoft Excel spreadsheet. ${ }^{93}$

87 SwOвODA et al. 2008 .

88 SwOBODA et al. 2008. - IRRGEHER et al. 2013.

89 Retzmann et al. 2017.

90 RetZmann et al. 2017.

91 Yang et al. 2008. - Kramchaninov, Chernyshev, Shatagin 2012. - Irrgeher et al. 2013. - Irrgeher et al. 2015. - Horsky, Irrgeher, Prohaska 2016. - Retzmann et al. 2017.

92 Retzmann et al. 2017.

93 Horsky, Irrgeher, Prohaska 2016.

\subsubsection{Data Reduction}

The local environmental Sr isotope ratio range of Stillfried/March was defined by the upper limit of the water $\left.n\left({ }^{87} \mathrm{Sr}\right) / n{ }^{86} \mathrm{Sr}\right)$ ratio range and the lower limit of the soil $\left.n\left({ }^{87} \mathrm{Sr}\right) / n{ }^{86} \mathrm{Sr}\right)$ ratio range. The Sr isotope range in water was determined by twice the standard deviation of all five recent water samples. The Sr isotope range in soil was calculated as twice the standard deviation of all seventeen recent soil samples.

An autochthonous $n\left({ }^{87} \mathrm{Sr}\right) / n\left({ }^{86} \mathrm{Sr}\right)$ ratio range was estimated by plus/minus twice the standard deviation of the mean $\left.n{ }^{87} \mathrm{Sr}\right) / n\left({ }^{86} \mathrm{Sr}\right)$ ratio of all prehistoric animal enamel samples as a proxy for the Sr diet, of prehistoric plant samples as a proxy for Sr in vegetation, and of prehistoric mussel samples as a proxy for Sr in drinking water. The $n\left({ }^{87} \mathrm{Sr}\right) / n\left({ }^{86} \mathrm{Sr}\right)$ ratio of the burial environment of Pit V841 was calculated as an average from soil (sign. 13307) and mudbrick (sign. 13289) samples taken from the pit.

The provenance of each analysed individual from Stillfried was classified by the comparison of enamel $n\left({ }^{87} \mathrm{Sr}\right) / n\left({ }^{86} \mathrm{Sr}\right)$ values to the corresponding local environmental Sr range and the autochthonous Sr range.

The $n\left({ }^{87} \mathrm{Sr}\right) / n\left({ }^{86} \mathrm{Sr}\right)$ isotope ratio data of the soil and water samples were assigned to the geographic coordinates of their sampling spot and imported into the geographical mapping software ArcGIS® 10.2 (ESRI, Redlands, CA, USA). By using geological and soil maps (eBOD, Bundesministerium für Nachhaltigkeit und Tourismus) of Stillfried/ March, a multi-layered isoscape was established. Existing geomorphological data were incorporated into the model to enable a more comprehensive interpretation (Figs. 11-12).

The biogenic Sr isotopic composition of the primary dentine for the five individuals that were identified as allochthonous individuals (see results) was estimated considering possible diagenetic alterations. The mathematical correction assumed that the primary source of diagenetic $\mathrm{Sr}$ is the burial environment. Consequently, the overall Sr isotopic ratio of the primary dentine shifts towards the diagenetic Sr value at a rate proportional to the amount of diagenetic $\mathrm{Sr}^{94}$ The biogenic Sr isotopic signatures in human primary dentine was therefore estimated as summarized in equation $1:^{95}$

$$
n\left({ }^{87} S r\right) / n\left({ }^{86} S r\right)_{b i o}=\frac{n\left({ }^{87} S r\right) / n\left({ }^{86} S r\right)_{\text {dentine }}-n\left({ }^{87} S r\right) / n\left({ }^{86} S r\right)_{\text {rep }} \cdot p \%_{\text {dia }}}{1-p \%_{\text {dia }}}
$$

94 Montgomery, Evans, Cooper 2007. - Copeland et al. 2010. 95 Copeland et al. 2010. - Kreutz 2011. 
where $n\left({ }^{87} \mathrm{Sr}\right) / n\left({ }^{86} \mathrm{Sr}\right)_{\text {bio }}$ and $n\left({ }^{87} \mathrm{Sr}\right) / n\left({ }^{86} \mathrm{Sr}\right)_{\text {dentine }}$ are the estimated biogenic and measured (diagenetic) Sr ratios in human primary dentine, $n\left({ }^{87} \mathrm{Sr}\right) / n\left({ }^{86} \mathrm{Sr}\right)_{\text {rep }}$ is the measured $\mathrm{Sr}$ ratio of the repository material and the diagenetic proportion $p \%_{\text {dia }}$. The latter is estimated from the measured Sr mass fractions $\beta$ measured in enamel and primary dentine considering the normal modern enrichment factor $f_{\text {enrich }}$ for $\mathrm{Sr}$ in human (primary) dentine, according to equation 2:

$$
p \%_{\text {dia }}=\frac{\beta(\text { Sr })_{\text {dentine }}-\beta(S r)_{\text {enamel }} \cdot f_{\text {enrich }}}{\beta(S r)_{\text {dentine }}}
$$

where an average enrichment factor of $f_{\text {enrich }}=1.2$ was applied. The average enrichment factor was calculated from the average $\mathrm{Sr}$ mass fractions for modern human enamel and dentine, given in Waleska Castro et al. ${ }^{96}$ Individual enrichment factors for the study ranged from 1.1 up to 1.7. Similar factors can be calculated for modern herbivores, omnivores and carnivores with data given in Matthew J. Kohn and Randolph J. Moses, ${ }^{97}$ and correspond to our own measurements of modern teeth (unpublished results). The uncertainty contribution of the enrichment factor $\left(U_{r e l}=20 \%\right)$ has a minor effect on the estimated biogenic $\mathrm{Sr}$ signature in human primary dentine. Generally, the major contributors for the uncertainty budget of the estimated biogenic Sr signature in human primary dentine are the uncertainties of the $n\left({ }^{87} \mathrm{Sr}\right) / n\left({ }^{86} \mathrm{Sr}\right)$ ratio measured in diagenetic altered primary dentine and the $n\left({ }^{87} \mathrm{Sr}\right) / n\left({ }^{86} \mathrm{Sr}\right)$ ratio measured of the repository material (sum $>65 \%$ ). It must be mentioned that the combined uncertainty $\left(u_{c}, k=1\right)$ increased significantly for diagenetic proportions $>50 \%$. Thus, we must consider the estimated primary dentine data with care.

\section{Results}

The $n\left({ }^{87} \mathrm{Sr}\right) / n\left({ }^{86} \mathrm{Sr}\right)$ ratios of the analysed samples are given in Tables 1-3. The Sr isotope ratios of water and soil samples within a radius of five kilometres around the hillfort site at Stillfried range between 0.70864 and 0.71077 (Tab. 3). The geological map and the soil map (Figs. 11-12) indicated that the sampling spots closer to the hillfort site tend towards higher $n\left({ }^{87} \mathrm{Sr}\right) / n\left({ }^{86} \mathrm{Sr}\right)$ ratios. The local environmental $n\left({ }^{87} \mathrm{Sr}\right) / n\left({ }^{86} \mathrm{Sr}\right)$ ratio (including recent soil and water samples) of Stillfried/March range from 0.70852 to 0.71113 and represent the local environmental bioavailable Sr range.

\subsection{The Local and Autochthonous $n\left({ }^{87} \mathrm{Sr}\right) / n\left({ }^{86} \mathrm{Sr}\right)$ Signal}

The $n\left({ }^{87} \mathrm{Sr}\right) / n\left({ }^{86} \mathrm{Sr}\right)$ ratios of enamel and dentine of the prehistoric faunal remains overlapped within their uncertainties. All enamel and dentine values approached the upper half of the local environmental Sr range (Fig. 13). Due to the consistency in Sr isotopic signatures and the fact that primary residential wild animals like boar and beaver, as well as domesticated animals like dogs and pigs were included, all enamel samples were used to identify an autochthonous signal.

The $n\left({ }^{87} \mathrm{Sr}\right) / n\left({ }^{86} \mathrm{Sr}\right)$ ratios of the mussel samples approached the upper half of the local environmental Sr range and overlapped with the local water Sr range (0.709190.71113 ) within their uncertainties (Fig. 13). This fact underlined the similarity of $n\left({ }^{87} \mathrm{Sr}\right) / n\left({ }^{86} \mathrm{Sr}\right)$ ratios of modern and historic water samples. ${ }^{98}$ Therefore, the data obtained from mussel samples were included into the calculation of a representative autochthonous signal, as a reference for potential drinking water sources. ${ }^{99}$

The $n\left({ }^{87} \mathrm{Sr}\right) / n\left({ }^{86} \mathrm{Sr}\right)$ ratios of straw and wood overlapped within their uncertainties. Both samples approached the upper limit of the local environmental Sr range and were included to provide a representative autochthonous signal (Fig. 13), since they are a reference for potential vegetation sources.

The resulting autochthonous $n\left({ }^{87} \mathrm{Sr}\right) / n\left({ }^{86} \mathrm{Sr}\right)$ ratio ranged from 0.70987 to 0.71130 and represents the potential $n\left({ }^{87} \mathrm{Sr}\right) / n\left({ }^{86} \mathrm{Sr}\right)$ signature, which was most likely bioavailable for human individuals.

The $n\left({ }^{87} \mathrm{Sr}\right) / n\left({ }^{86} \mathrm{Sr}\right)$ ratio of the leachable Sr of the two soil samples taken from Pit V841, overlapped within uncertainties and lay in the upper half of the local environmental and autochthonous Sr ranges (Fig. 13). Hence, these soil samples and herewith the burial environment was determined as $0.71046 \pm 0.00019$, supporting the estimated autochthonous Sr range.

\subsection{Diagenetic Effects}

The Sr content in enamel of the investigated individuals ranged from $71 \mu \mathrm{g} \mathrm{g}^{-1} \pm 11 \mu \mathrm{g} \mathrm{g}^{-1}$ to $199 \mu \mathrm{g} \mathrm{g}^{-1} \pm 30 \mu \mathrm{g} \mathrm{g}^{-1}$ (Tab. 1). This is in accordance with normal modern Sr mass fractions of human enamel that are known to be geographically variable and lifestyle-dependent, and typically range between $50 \mu \mathrm{g} \mathrm{g}^{-1}$ and $300 \mu \mathrm{g} \mathrm{g}^{-1} .{ }^{100}$ The Sr mass fraction of enamel of the eleven human individuals from the hillfort site at Stillfried/March can be considered as biogenic.

98 In agreement with observations by MAURER et al. 2012.

99 The edible mussels were not approximated by the Sr signature of the shell.

100 Montgomery, Evans, Cooper 2007. - Castro et al. 2010. DudÁs et al. 2016.

96 CASTro et al. 2010.

97 Kohn, Moses 2013. 


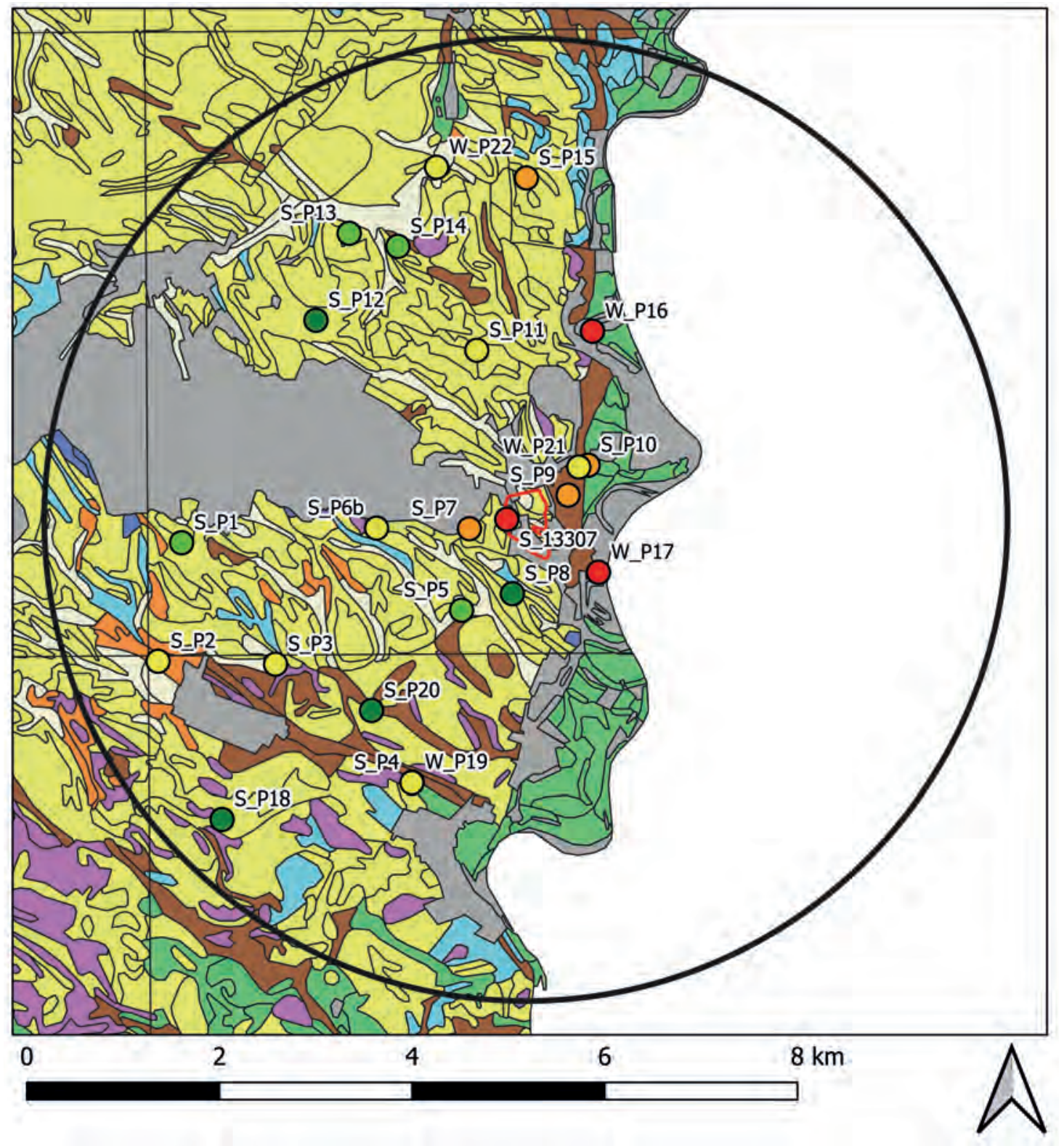

\begin{tabular}{ll}
\hline Settlement & $\square$ Uncharted \\
\hline 5 km radius & Sr ratios \\
$\square$ Limestone & $\bigcirc 0.70864-0.70906$ \\
$\square$ Fine sediment & $\bigcirc 0.70906-0.70948$ \\
$\square$ Tertiary sediment & $\bigcirc 0.70948-0.70990$ \\
$\square$ Sand & $\bigcirc 0.70990-0.71032$ \\
$\square$ Alluvium & $\bigcirc 0.71032-0.71074$ \\
$\square$ Clayey fine sediment \\
$\square$ Colluvium
\end{tabular}

Fig. 11. Geological map of Stillfried/March showing the $n\left({ }^{87} \mathrm{Sr}\right) / n\left({ }^{86} \mathrm{Sr}\right)$ ratios of the soil and water samples in a five-kilometre radius around the settlement (Map: Digitale Bodenkarte von Österreich, $1 \mathrm{~km}$-Raster, Bundesforschungs- und Ausbildungszentrum für Wald, Naturgefahren und Landschaft (BFW), map processing by F. Köstelbauer). 


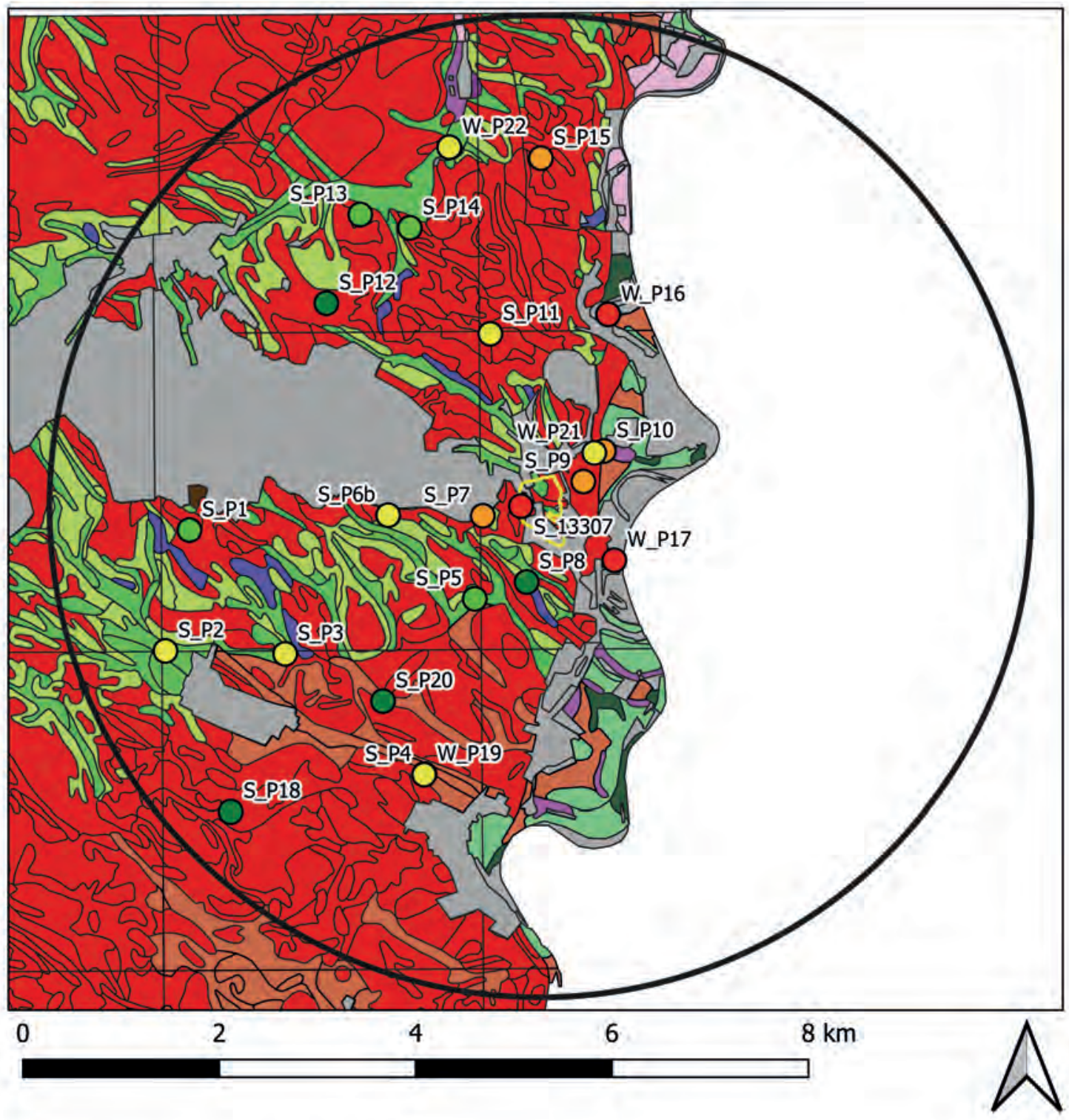

\begin{tabular}{|c|c|}
\hline Partially weathered floodplain & Uncharted \\
\hline Heavily weathered floodplain & $-5 \mathrm{~km}$ radius \\
\hline Gley & Settlement \\
\hline Typical gley & Sr ratios \\
\hline Extreme gley & $0.70864-0.70906$ \\
\hline Chernozem (humid) & $0.70906-0.70948$ \\
\hline Chernozem (arid) & $0.70948-0.70990$ \\
\hline Soil forming complex & $0.70990-0.71032$ \\
\hline Colluvium & $0.71032-0.71074$ \\
\hline
\end{tabular}

Fig. 12. Soil map of Stillfried/March showing the $n\left({ }^{87} \mathrm{Sr}\right) / n\left({ }^{86} \mathrm{Sr}\right)$ ratios of the soil and water samples in a five-kilometre radius around the settlement (Map: Digitale Bodenkarte von Österreich, $1 \mathrm{~km}$-Raster, Bundesforschungs- und Ausbildungszentrum für Wald, Naturgefahren und Landschaft (BFW), map processing by F. Köstelbauer). 

- Animal Enamel
- Archaeological Plants
....... A utochthonous Range

․ Animal Dentine

$\Delta$ Archaeological Soils

- M ussel

- Local Environmental Range

0.71200

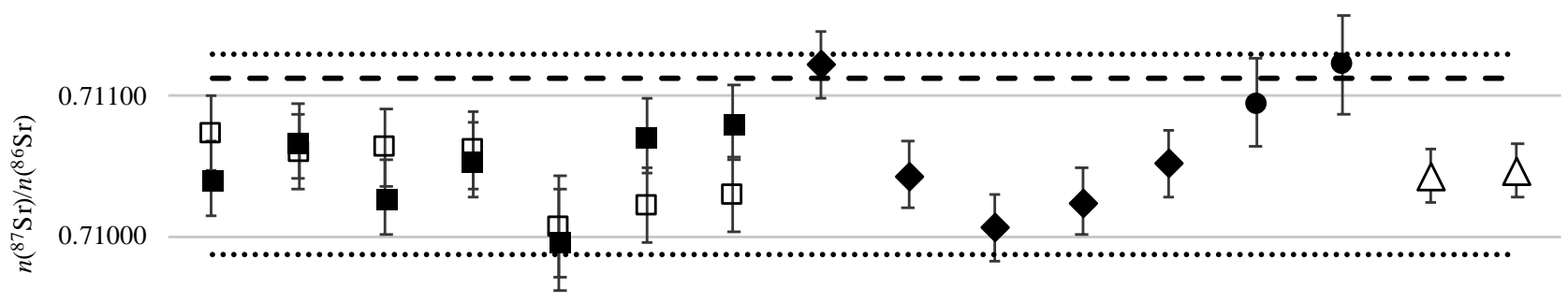

0.70900

0.70800

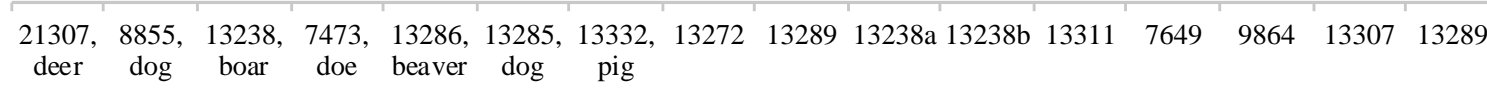

Fig. 13. The $n\left({ }^{87} \mathrm{Sr}\right) / n\left({ }^{86} \mathrm{Sr}\right)$ ratios of archaeological animals (enamel, dentine), mussels, plants (straw, wood) and soils (taken from Pit V841), and the calculated autochthonous range, compared to the calculated local environmental range. Error bars correspond to expanded uncertainty $U(k=2)$.

The elevated elemental contents (mainly Ba, V, Sr) ${ }^{101}$ of human primary dentine from all investigated individuals indicated diagenetic alterations. Interestingly, these changes are less pronounced in the present study that used premolar pulp dentine (Tab. 1) than in a previous study ${ }^{102}$ that used molar root dentine.

Sr mass fractions of enamel and dentine are comparable due to in vivo assimilation, ${ }^{103}$ and, therefore, a significantly higher Sr content in the primary dentine is likely due to post mortem Sr addition by diagenetic processes. ${ }^{104}$ The estimated diagenetic proportion of $\mathrm{Sr}$ in primary dentine samples ranged from $11 \%$ to $94 \%$ (Tab. 1). The diagenetic proportion of $\mathrm{Sr}$ in primary dentine of deciduous teeth, such as in SK 10 (sign. 9051/V841) and SK 4 (sign. 9026/V1141), tended to be higher. This might be related to the differing chemical composition and significant lower Sr contents of

101 Kohn, Schoeninger, Barker 1999. - Trueman et al. 2008. Koenig, Rogers, Trueman 2009. - Kohn, Moses 2013. - Benson et al. 2013. - Willmes et al. 2016. - Kamenov et al. 2018.

102 Teschler-Nicola, Irrgeher, Prohaska 2016.

103 Budd et al. 2000. - Dudás et al. 2016.

104 Chiaradia, Gallay, Todt 2003. deciduous teeth. ${ }^{105}$ Since the primary dentine samples were found to be highly affected by diagenetic alterations, biogenic $n\left({ }^{87} \mathrm{Sr}\right) / n\left({ }^{86} \mathrm{Sr}\right)$ ratios of primary dentine of the (supposedly) allochthonous individuals were calculated (Tab. 1).

\subsection{Sr Isotope Signals in Human Remains 3.3.1. Stillfried Settlement Pit V1141}

The measured $n\left({ }^{87} \mathrm{Sr}\right) / n\left({ }^{86} \mathrm{Sr}\right)$ ratios of enamel of SK 1 (sign. 9023) did not lie within the local environmental and autochthonous Sr ranges and classified SK 1 as a possible allochthonous individual. The measured Sr isotopic signal of primary dentine did not overlap within uncertainties with the enamel signal and overlapped within uncertainties with the upper end of the autochthonous Sr ranges (Fig. 14).

The measured $n\left({ }^{87} \mathrm{Sr}\right) / n\left({ }^{86} \mathrm{Sr}\right)$ ratios of enamel and primary dentine of SK 4 (sign. 9026) on the other hand, were indistinguishable from both the local environment and autochthonous Sr ranges and overlapped within their uncertainties. Hence, SK 4 was classified as a supposedly autochthonous individual.

105 Williams et al. 2002. 


\begin{tabular}{|c|c|c|c|c|c|c|c|c|c|c|c|c|c|c|c|}
\hline 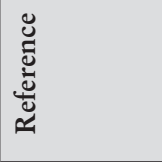 & \multicolumn{2}{|l|}{ 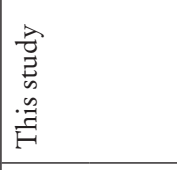 } & \multicolumn{2}{|l|}{ 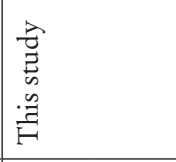 } & \multicolumn{2}{|l|}{ 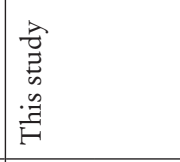 } & \multicolumn{2}{|l|}{ 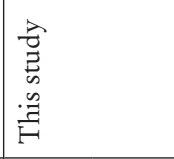 } & \multicolumn{2}{|l|}{ 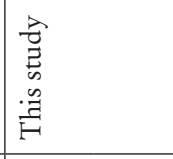 } & \multicolumn{2}{|l|}{ 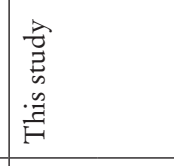 } & \multicolumn{2}{|l|}{ 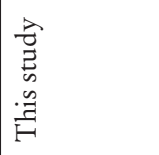 } & 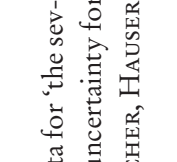 \\
\hline 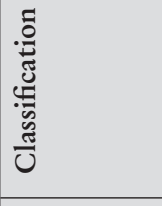 & \multicolumn{2}{|l|}{ 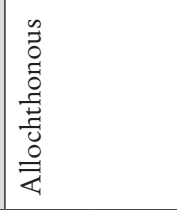 } & \multicolumn{2}{|c|}{ 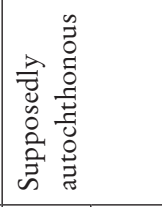 } & \multicolumn{2}{|l|}{ 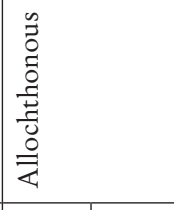 } & \multicolumn{2}{|l|}{ 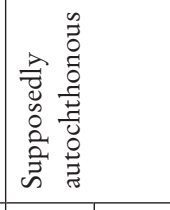 } & \multicolumn{2}{|l|}{ 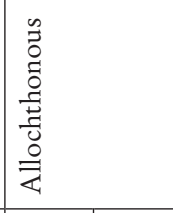 } & \multicolumn{2}{|l|}{ 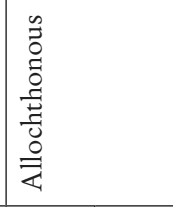 } & \multicolumn{2}{|c|}{ 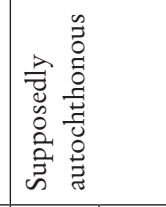 } & 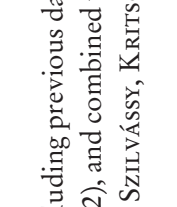 \\
\hline 莺 & & 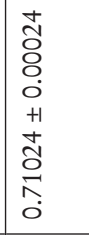 & & & & 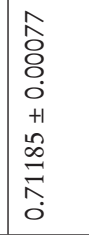 & & & & 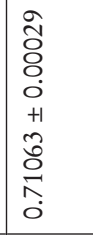 & & $\begin{array}{l}\infty \\
0 \\
0 \\
0 \\
0 \\
0 \\
+1 \\
0 \\
0 \\
0 \\
0 \\
0 \\
0\end{array}$ & & & 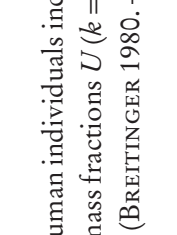 \\
\hline 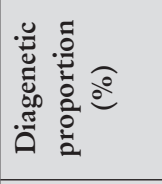 & & $\begin{array}{l}0 \\
i n \\
+1 \\
0 \\
0 \\
0 \\
0\end{array}$ & & $\begin{array}{l}\therefore \\
= \\
+1 \\
\therefore \circ \\
0 \\
k\end{array}$ & & 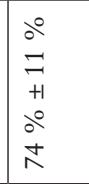 & & $\begin{array}{l}\therefore \\
=1 \\
+1 \\
\therefore \circ \\
i\end{array}$ & & 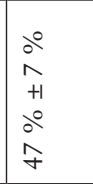 & & $\begin{array}{l}20 \\
2 \\
2 \\
+1 \\
\therefore \\
0 \\
0 \\
0\end{array}$ & & $\begin{array}{l}\therefore 0 \\
0 \\
+1 \\
+0 \\
0 \\
0\end{array}$ & 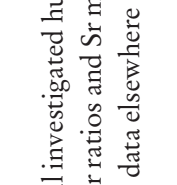 \\
\hline 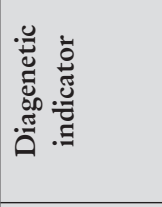 & & 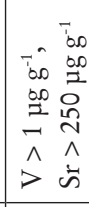 & & 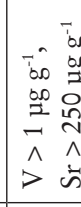 & & 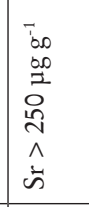 & & 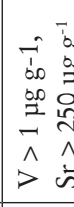 & & 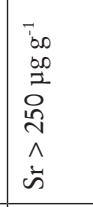 & & 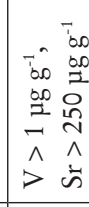 & & $\begin{array}{l}50 \\
60 \\
00 \\
0 \\
0 \\
i j \\
\hat{n} \\
\dot{n} \\
\end{array}$ & 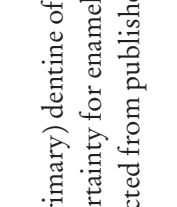 \\
\hline 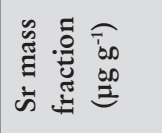 & $\begin{array}{c}0 \\
0 \\
0+1 \\
0 \\
2 \\
2\end{array}$ & $\begin{array}{l}1 \\
i n \\
+1 \\
0 \\
m\end{array}$ & $\begin{array}{l}n \\
+1 \\
a \\
\alpha\end{array}$ & 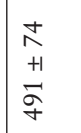 & $\begin{array}{l}1 \\
\cdots \\
+1 \\
\infty \\
\infty\end{array}$ & $\begin{array}{l}\text { in } \\
\text { on } \\
0 \\
0 \\
m\end{array}$ & 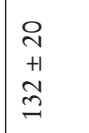 & $\begin{array}{l}+ \\
0 \\
+1 \\
0 \\
0 \\
i n\end{array}$ & $\begin{array}{l}2 \\
0 \\
1 \\
0 \\
0 \\
0 \\
0\end{array}$ & $\begin{array}{l}f \\
f \\
+1 \\
0 \\
0\end{array}$ & $\begin{array}{l}z \\
+1 \\
i\end{array}$ & 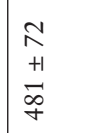 & $\begin{array}{l}\stackrel{2}{2} \\
+1 \\
\hat{y}\end{array}$ & $\begin{array}{l}4 \\
8 \\
0 \\
0 \\
0 \\
0\end{array}$ & 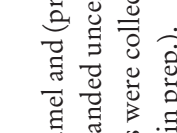 \\
\hline 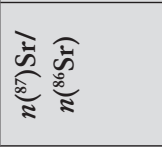 & $\begin{array}{ll}+1 & \\
0 & 0 \\
0 & \bar{\delta} \\
0 & 0 \\
0 & 0 \\
0 & 0 \\
\end{array}$ & 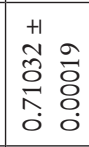 & 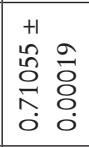 & 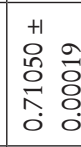 & 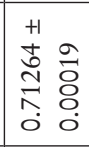 & 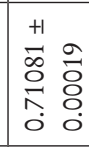 & 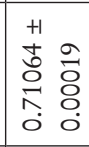 & \begin{tabular}{ll}
+1 \\
+1 \\
0 \\
0 \\
0 \\
\multirow{2}{*}{} & 8 \\
0 & 0 \\
0 & 0 \\
\end{tabular} & 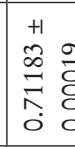 & 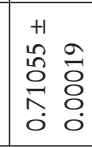 & $\begin{array}{ll}++1 & \\
0 & 0 \\
0 & \overline{8} \\
0 & 0 \\
0 & 0 \\
0 & 0 \\
\end{array}$ & 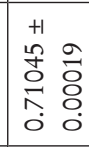 & 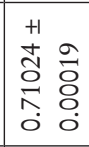 & 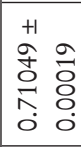 & 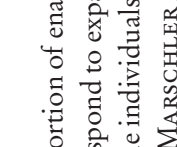 \\
\hline 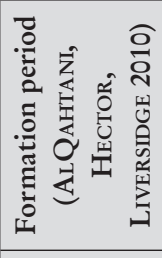 & 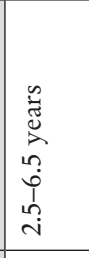 & 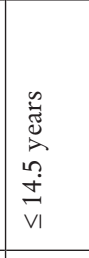 & & & 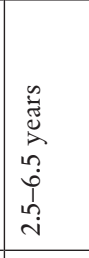 & 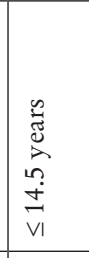 & & & 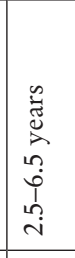 & 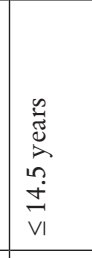 & 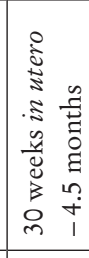 & 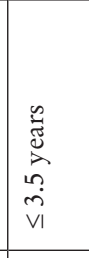 & & & 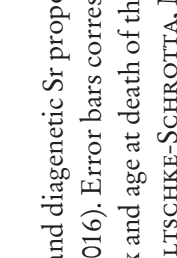 \\
\hline 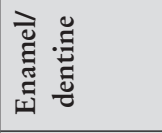 & 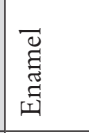 & 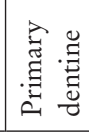 & 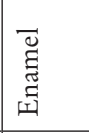 & 密. & 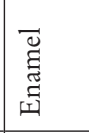 & 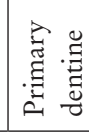 & 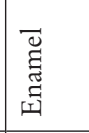 & 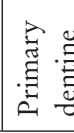 & 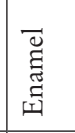 & 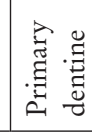 & $\begin{array}{l}\overline{\widetilde{\Xi}} \\
\text { ज्ञ } \\
\text { 至 }\end{array}$ & 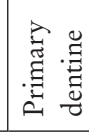 & \begin{tabular}{|l}
$\vec{\Xi}$ \\
ज్ \\
ज्ञ
\end{tabular} & 离. & 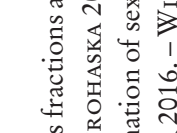 \\
\hline 咅 $\widehat{\circ}$ & \pm & & $\stackrel{n}{\sim}$ & & $\stackrel{ \pm}{\sim}$ & & \pm & & \pm & & ț & & \pm & & 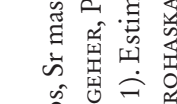 \\
\hline 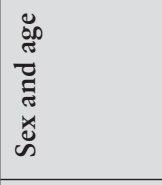 & 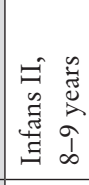 & & 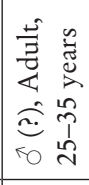 & & 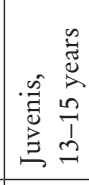 & & 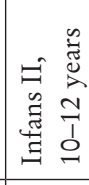 & & 㻤高 & & 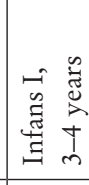 & & 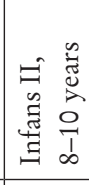 & & 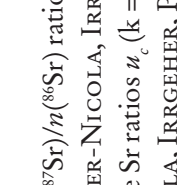 \\
\hline$\ddot{\theta}$ & $\begin{array}{l}\overrightarrow{0} \\
\stackrel{0}{\rho} \\
;\end{array}$ & & 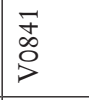 & & \begin{tabular}{|l}
$F$ \\
$\stackrel{0}{\circ}$ \\
$\stackrel{8}{9}$
\end{tabular} & & 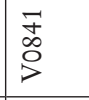 & & $\begin{array}{l}\vec{f} \\
\stackrel{0}{\rho} \\
\stackrel{8}{>}\end{array}$ & & $\begin{array}{l}\vec{f} \\
\stackrel{0}{>} \\
\rho\end{array}$ & & $\begin{array}{l}F \\
\stackrel{f}{0} \\
\stackrel{8}{>}\end{array}$ & & 5 \\
\hline$\underset{\dot{5}}{\dot{5}}$ & ปั & & 产 & & 寺 & & 京 & & 高 & & 공 & & 승 & & 57 \\
\hline 要 & $\ddot{n}$ & & $\frac{2}{2}$ & & 立 & & $\begin{array}{l}\dot{n} \\
\ddot{n}=\end{array}$ & & $\begin{array}{l}\infty \\
\infty \\
\infty\end{array}$ & & 흥ㅇ & & $\ddot{n}=$ & & $\overrightarrow{0}$ \\
\hline
\end{tabular}




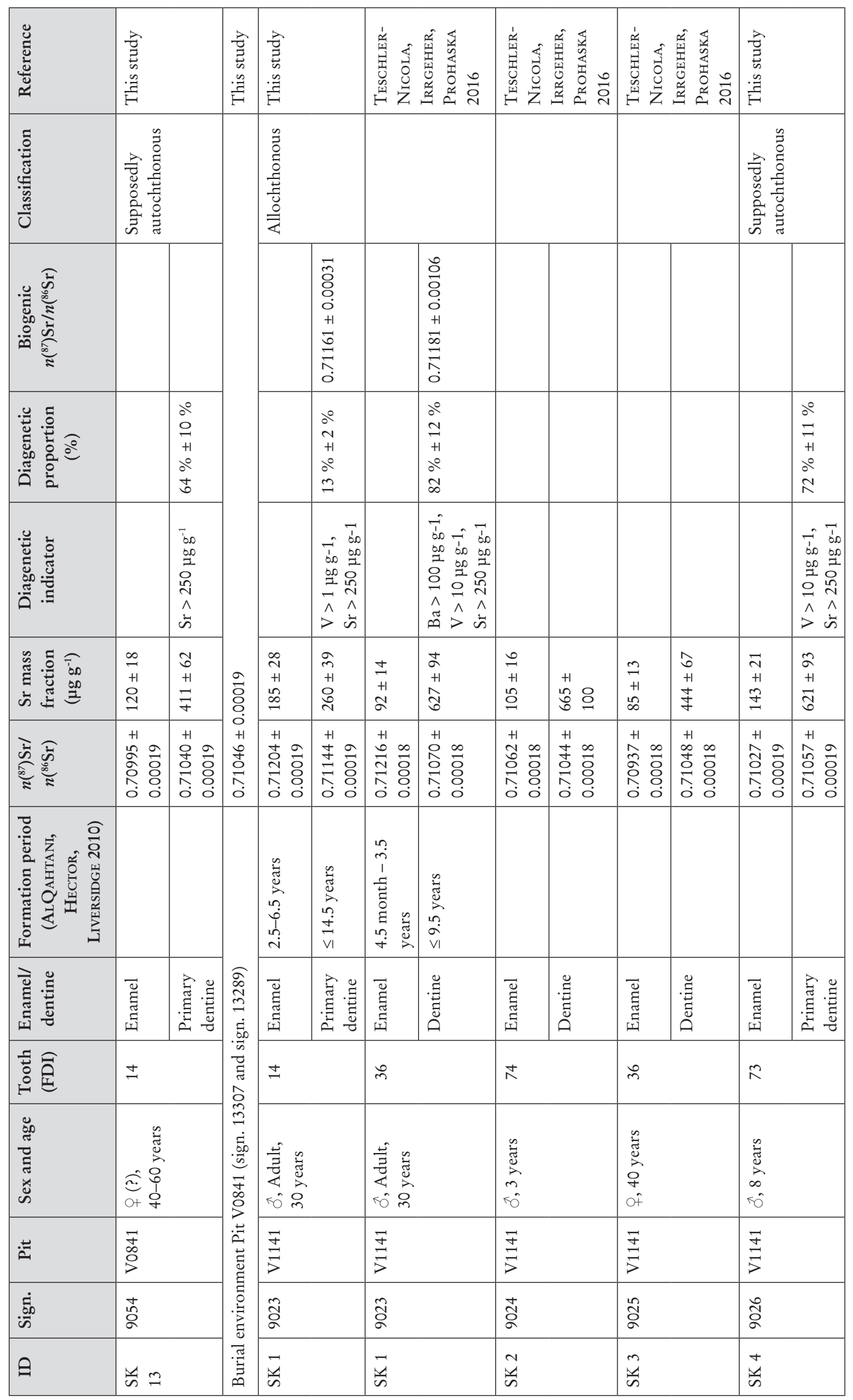

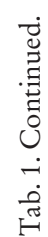




\begin{tabular}{|c|c|c|c|c|c|c|c|c|c|c|}
\hline 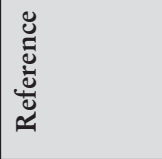 & \multicolumn{2}{|c|}{ 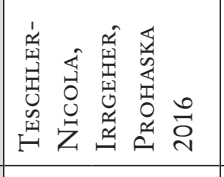 } & \multicolumn{2}{|c|}{ 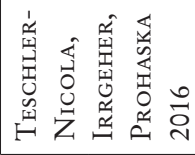 } & \multicolumn{2}{|c|}{ 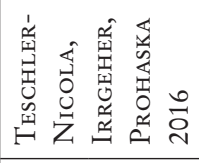 } & \multicolumn{2}{|c|}{ 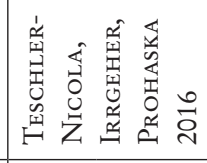 } & \multicolumn{2}{|l|}{ 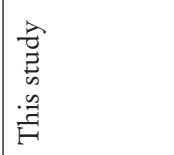 } \\
\hline 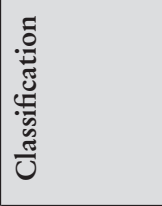 & & & & & & & & & 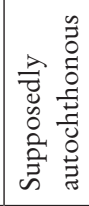 & \\
\hline 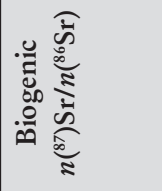 & & & & & & & & & & \\
\hline 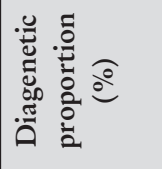 & & & & & & & & & & $\begin{array}{l}\circ \\
\infty \\
+1 \\
0 \\
0 \\
\text { in }\end{array}$ \\
\hline 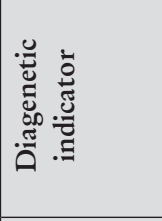 & & 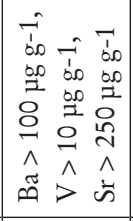 & & & & & & & & 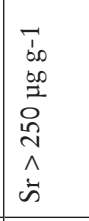 \\
\hline 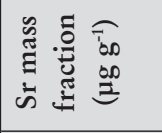 & $\begin{array}{l}a \\
+1 \\
\Xi \\
\Xi\end{array}$ & 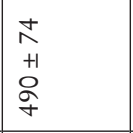 & $\begin{array}{l}\hat{\imath} \\
+1 \\
\check{I} \\
\end{array}$ & $\begin{array}{l}\hat{n} \\
+1 \\
\vec{n}\end{array}$ & $\begin{array}{l} \pm \\
+ \\
+1 \\
2\end{array}$ & $\begin{array}{l}\infty \\
a \\
+1 \\
\hat{乃} \\
0\end{array}$ & $\begin{array}{l}0 \\
+1 \\
+1 \\
b\end{array}$ & $\begin{array}{l}\infty \\
\infty \\
+1 \\
\hat{i} \\
i n\end{array}$ & $\begin{array}{l}a \\
+1 \\
\ddot{\Xi}\end{array}$ & 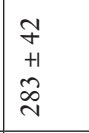 \\
\hline 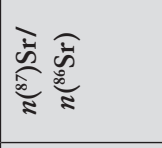 & $\begin{array}{|ll|}+1 & \\
O & \infty \\
0 & \mathbb{8} \\
\hat{R} & 0 \\
0 & 0 \\
0 & 0 \\
\end{array}$ & 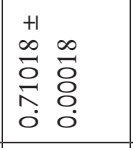 & 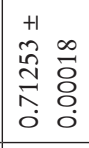 & 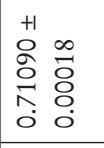 & 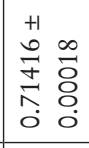 & 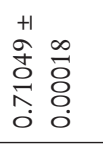 & $\begin{array}{|ll|}+1 & \\
\infty & \infty \\
\infty & 0 \\
2 & 0 \\
& 0 \\
0 & 0 \\
\end{array}$ & \begin{tabular}{|ll}
+1 & \\
+1 & $\infty$ \\
$\infty$ & 0 \\
0 & 0 \\
0 & 8 \\
0 & 0 \\
0 & 0 \\
\end{tabular} & 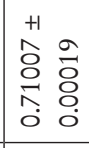 & 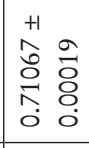 \\
\hline 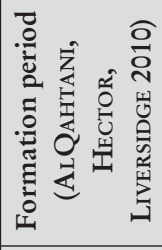 & & & & & & & & & & \\
\hline 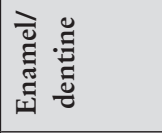 & 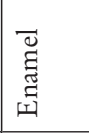 & $\begin{array}{l}\tilde{\Xi} \\
. \bar{\Xi} \\
\varrho\end{array}$ & 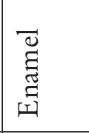 & 节 & 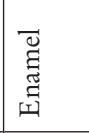 & 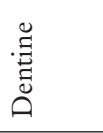 & 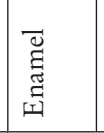 & 节 & 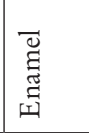 & 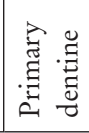 \\
\hline 营危 & $\hat{m}$ & & f & & $\stackrel{n}{\kappa}$ & & $\stackrel{m}{2}$ & & \pm & \\
\hline 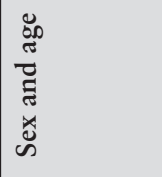 & 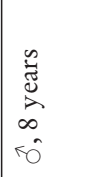 & & 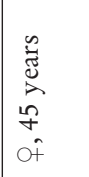 & & $\begin{array}{l}0 \\
5 \\
5 \\
5 \\
0 \\
0 \\
0 \\
\text { ro }\end{array}$ & & 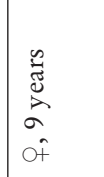 & & 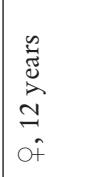 & \\
\hline$\ddot{\theta}$ & $\underset{F}{F}$ & & $\underset{F}{F}$ & & $\underset{F}{F}$ & & $\underset{F}{F}$ & & $\stackrel{2}{\stackrel{7}{5}}$ & \\
\hline$\dot{\dot{g}}$ & ふু & & $\widehat{\widehat{\sigma}}$ & & 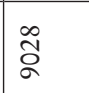 & & ふু & & 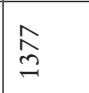 & \\
\hline$\theta$ & $\underset{\dot{\omega}}{\Delta}$ & & $\begin{array}{l}n \\
\vdots \\
\vdots\end{array}$ & & $\begin{array}{l}0 \\
\ddot{4}\end{array}$ & & $\hat{n}$ & & & \\
\hline
\end{tabular}

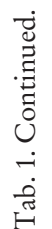




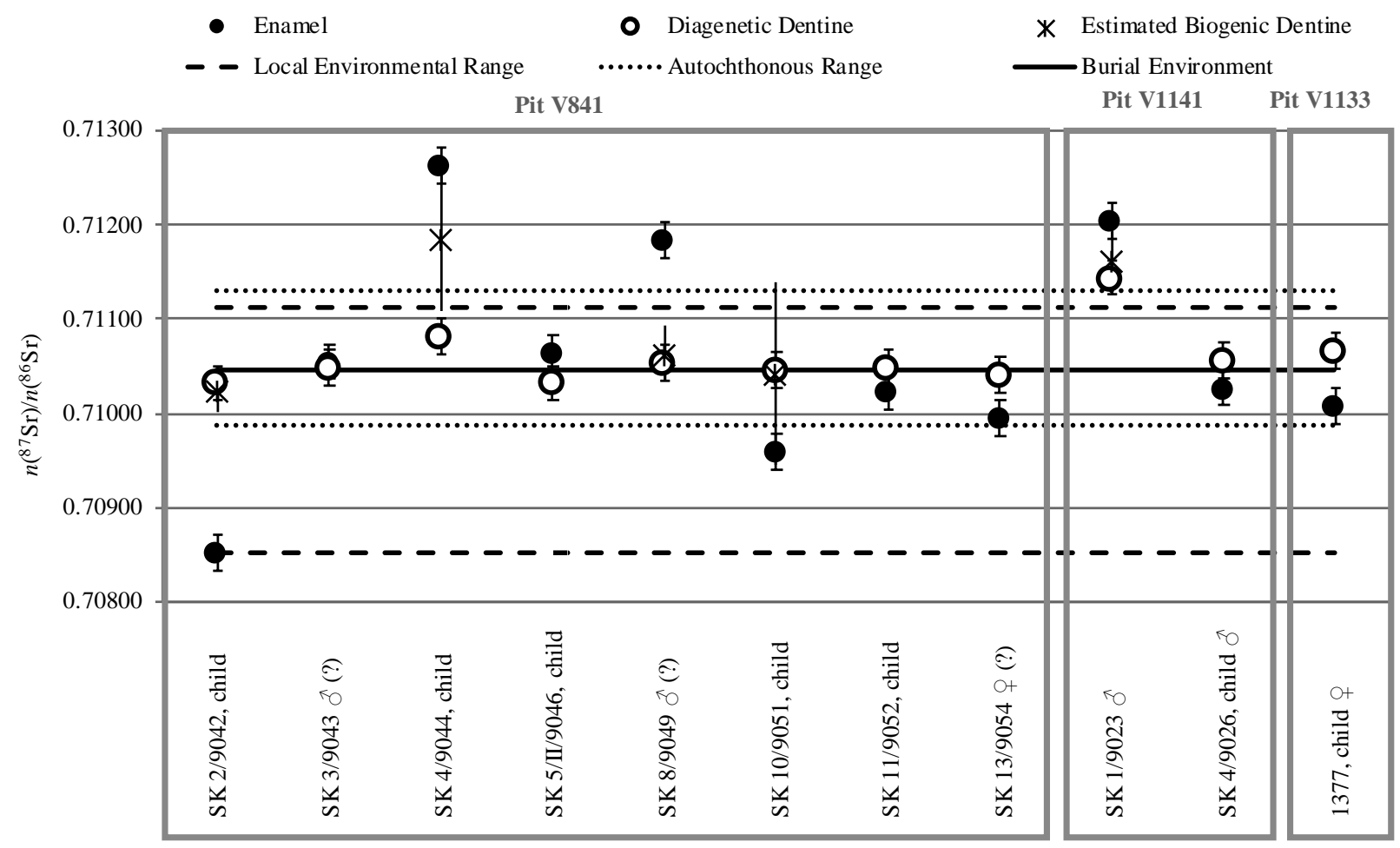

Fig. 14. The $n\left({ }^{87} \mathrm{Sr}\right) / n\left({ }^{86} \mathrm{Sr}\right)$ ratios of enamel and primary dentine (diagenetic and partly biogenic) from all investigated human individuals, ordered by pits and compared to the local environmental and autochthonous $\mathrm{Sr}$ ranges. Error bars correspond to expanded uncertainty for enamel Sr ratios $U(k=2)$ and combined uncertainty for biogenic primary dentine Sr ratios $u_{c}(k=1)$.

\subsubsection{Stillfried Settlement Pit V1133}

The child from Pit V1133 shows $n\left({ }^{87} \mathrm{Sr}\right) / n\left({ }^{86} \mathrm{Sr}\right)$ ratios that were indistinguishable from the local environmental and autochthonous Sr ranges. However, one can see a significant difference between the enamel and primary dentine. The enamel signature is placed at the lower end of the autochthonous Sr range whereas the primary dentine signature was located at the upper end of the local environmental and autochthonous Sr ranges and was closer to the soil samples taken from the pit (Fig 14). Nonetheless, the child was classified as a supposedly autochthonous individual.

\subsubsection{Stillfried Settlement Pit V841}

The measured $n\left({ }^{87} \mathrm{Sr}\right) / n\left({ }^{86} \mathrm{Sr}\right)$ ratios of enamel and primary dentine of both analysed individuals (SK 11/sign. 9052, SK 13/sign. 9054) from skeletal layer 1, were indistinguishable from both the local environmental and autochthonous Sr ranges and, therefore, classified as supposedly autochthonous individuals (Fig. 14).

The measured $n\left({ }^{87} \mathrm{Sr}\right) / n\left({ }^{86} \mathrm{Sr}\right)$ ratios of enamel and primary dentine of both individuals (SK 8/sign. 9049, SK 10/sign.
9051) of skeletal layer 2 did not overlap within their uncertainties. The enamel signal of SK 8 lay clearly outside the local environmental and autochthonous Sr ranges, which allowed classification as an allochthonous individual. The measured $\left.n\left({ }^{87} \mathrm{Sr}\right) / n{ }^{86} \mathrm{Sr}\right)$ ratios of deciduous enamel (formation starts in-utero ${ }^{106}$ ) of the 3-4-year-old child SK 10 lay within the local environmental range, but outside of the autochthonous range. At this point, its classification based on the enamel signature was not definitively clarified. The Sr isotopic value of the enamel displayed a significantly lower value compared to primary dentine.

The $n\left({ }^{87} \mathrm{Sr}\right) / n\left({ }^{86} \mathrm{Sr}\right)$ ratios of enamel and primary dentine of individuals selected from layer 3, SK 3 (sign. 9043) and SK 5/2 (sign. 9046), were indistinguishable from both local environmental and autochthonous Sr ranges (Fig. 14). Therefore, these individuals were classified as supposedly autochthonous individuals.

SK 4 (sign. 9044) from layer 3 and SK 2 (sign. 9042) from layer 4 showed different enamel $n\left({ }^{87} \mathrm{Sr}\right) / n\left({ }^{86} \mathrm{Sr}\right)$ ratios. The signal of enamel of SK 2 lay at the very lower end of the local environmental Sr range, whereas the measured primary

106 AlQahtani, Hector, Liversidge 2010. 


\begin{tabular}{|c|c|c|c|c|c|}
\hline ID & Pit & Type & Tooth & Enamel/Dentine & $n\left({ }^{87}\right) \mathrm{Sr} / n\left({ }^{86} \mathrm{Sr}\right)$ \\
\hline \multirow{2}{*}{7473} & \multirow{2}{*}{1140} & \multirow{2}{*}{ Doe } & \multirow{2}{*}{ Isolated incisivus } & Enamel & $0.71054 \pm 0.00027$ \\
\hline & & & & Dentine & $0.71062 \pm 0.00027$ \\
\hline \multirow{2}{*}{8855} & \multirow{2}{*}{ V601 } & \multirow{2}{*}{ Dog } & \multirow{2}{*}{ Upper M2 } & Enamel & $0.71068 \pm 0.00027$ \\
\hline & & & & Dentine & $0.71061 \pm 0.00027$ \\
\hline \multirow{2}{*}{21307} & \multirow{2}{*}{ V2784-V3784 } & \multirow{2}{*}{ Deer } & \multirow{2}{*}{ Upper premolar } & Enamel & $0.71041 \pm 0.00027$ \\
\hline & & & & Dentine & $0.71074 \pm 0.00027$ \\
\hline \multirow{2}{*}{13285} & \multirow{2}{*}{ V841 } & \multirow{2}{*}{ Dog } & \multirow{2}{*}{ Caninus (?) } & Enamel & $0.71072 \pm 0.00027$ \\
\hline & & & & Dentine & $0.71023 \pm 0.00027$ \\
\hline \multirow{2}{*}{13238} & \multirow{2}{*}{ V841 } & \multirow{2}{*}{ Boar } & \multirow{2}{*}{ Caninus (?) } & Enamel & $0.71028 \pm 0.00027$ \\
\hline & & & & Dentine & $0.71064 \pm 0.00027$ \\
\hline \multirow{2}{*}{13286} & \multirow{2}{*}{ V841 } & \multirow{2}{*}{ Beaver } & & Enamel & $0.70998 \pm 0.00027$ \\
\hline & & & & Dentine & $0.71008 \pm 0.00027$ \\
\hline \multirow{2}{*}{13332} & \multirow{2}{*}{ V841 } & \multirow{2}{*}{ Pig } & & Enamel & $0.71082 \pm 0.00027$ \\
\hline & & & & Dentine & $0.71031 \pm 0.00027$ \\
\hline 13311 & V841 & Mussel & & & $0.71053 \pm 0.00024$ \\
\hline 13272 & V841 & Mussel & & & $0.71123 \pm 0.00024$ \\
\hline $13238 \mathrm{a}$ & V841 & Mussel & & & $0.71007 \pm 0.00024$ \\
\hline $13238 \mathrm{~b}$ & V841 & Mussel & & & $0.71025 \pm 0.00024$ \\
\hline 13289 & V841 & Mussel & & & $0.71044 \pm 0.00024$ \\
\hline 7649 & V1154 & Charred straw & & & $0.71116 \pm 0.00030$ \\
\hline 9864 & V1154 & Wooden balk & & & $0.71110 \pm 0.00035$ \\
\hline 13307 & V841 & Charcoal and soil & & & $0.71044 \pm 0.00017$ \\
\hline 13289 & V841 & Mudbrick & & & $0.71048 \pm 0.00017$ \\
\hline
\end{tabular}

Tab. 2. The $n\left({ }^{87} \mathrm{Sr}\right) / n\left({ }^{86} \mathrm{Sr}\right)$ ratios of all investigated animal individuals (enamel and dentine), mussels and archaeological environmental samples. Error bars correspond to expanded uncertainty $U(k=2)$.

dentine Sr signal lay within the local environmental and autochthonous Sr ranges. At this point, its classification based on the enamel signature was not definitively clarified. The Sr signal of enamel of SK 4 lay higher than the local environmental and autochthonous Sr ranges. Hence, the 13-15-year-old individual SK 4 was classified as an allochthonous individual.

\section{Discussion}

However, one needs to stress that the number of human individuals selected and handed over for $\mathrm{Sr}$ isotope ratio analysis in the course of the present study is extremely small. Based on this fact, we had to abstain from statistical analysis that could verify possible age- and gender-based migration patterns in Stillfried's Late Bronze Age population or chronological relations.

\subsection{Definition of Autochthony}

Even though Sr isotopes applied in migration studies is a method of exclusion and identifies only allochthony, it is likely for an individual to be autochthonous (also called 'local'), when found with a $n\left({ }^{87} \mathrm{Sr}\right) / n\left({ }^{86} \mathrm{Sr}\right)$ signature indistinguishable from the local environmental and autochthonous Sr range.

In general, the identification of allochthonous or supposedly autochthonous individuals is based on the determination of the autochthonous (commonly called bioavailable) $n\left({ }^{87} \mathrm{Sr}\right) / n\left({ }^{86} \mathrm{Sr}\right)$ signature of the habitat under investigation. The autochthonous $n\left({ }^{87} \mathrm{Sr}\right) / n\left({ }^{86} \mathrm{Sr}\right)$ signature in the food chain cannot be derived directly from the known isotopic composition of the underlying bedrock geology, ${ }^{107}$ as significant heterogeneity in Sr signatures of the different compartments in a given habitat can occur. ${ }^{108}$

107 Price, Burton, Bentley 2002.

108 Price, Burton, Bentley 2002. 


\begin{tabular}{|c|c|c|c|c|c|}
\hline ID & Type & lat. $\left({ }^{\circ} \mathrm{N}\right)$ & lon. $\left({ }^{\circ} \mathrm{E}\right)$ & Sampling spot & $n\left({ }^{87} \mathrm{Sr}\right) / n\left({ }^{86} \mathrm{Sr}\right)$ \\
\hline ST_S_P1 & Soil & 48.41224 & 16.79142 & Uncultivated field & $0.70929 \pm 0.00034$ \\
\hline ST_S_P2 & Soil & 48.40117 & 16.78802 & Uncultivated field & $0.70949 \pm 0.00029$ \\
\hline ST_S_P3 & Soil & 48.40083 & 16.80449 & - & $0.70955 \pm 0.00029$ \\
\hline ST_S_P4 & Soil & 48.38968 & 16.8235 & Uncultivated field & $0.70955 \pm 0.00029$ \\
\hline ST_S_P5 & Soil & 48.40577 & 16.83062 & Uncultivated field & $0.70948 \pm 0.00029$ \\
\hline ST_S_P6b & Soil & 48.41349 & 16.81878 & Vineyard & $0.70980 \pm 0.00029$ \\
\hline ST_S_P7 & Soil & 48.41338 & 16.8318 & Nearby vineyard & $0.71004 \pm 0.00029$ \\
\hline ST_S_P8 & Soil & 48.40728 & 16.83777 & Uncultivated field & $0.70890 \pm 0.00029$ \\
\hline ST_S_P9 & Soil & 48.41646 & 16.84567 & Ploughed field & $0.70994 \pm 0.00017$ \\
\hline ST_S_P10 & Soil & 48.41925 & 16.84852 & Nearby groves & $0.71024 \pm 0.00017$ \\
\hline ST_S_P11 & Soil & 48.43006 & 16.833002 & Hedge bank & $0.70965 \pm 0.00017$ \\
\hline ST_S_P12 & Soil & 48.43296 & 16.81046 & Hedge bank & $0.70864 \pm 0.00017$ \\
\hline ST_S_P13 & Soil & 48.44107 & 16.8152 & Hedge bank & $0.70915 \pm 0.00017$ \\
\hline ST_S_P14 & Soil & 48.43982 & 16.82202 & Hedge bank & $0.70940 \pm 0.00017$ \\
\hline ST_S_P15 & Soil & 48.44614 & 16.84012 & Ploughed field & $0.71002 \pm 0.00017$ \\
\hline ST_S_P18 & Soil & 48.38642 & 16.79686 & Uncultivated field & $0.70905 \pm 0.00018$ \\
\hline ST_S_P20 & Soil & 48.39645 & 16.81791 & - & $0.70866 \pm 0.00017$ \\
\hline ST_W_P16 & Water & 48.43177 & 16.84924 & Backwater of March by Hufeisenteich & $0.71050 \pm 0.00017$ \\
\hline ST_W_P17 & Water & 48.40923 & 16.84986 & March & $0.71077 \pm 0.00017$ \\
\hline ST_W_P19 & Water & 48.38973 & 16.82354 & Moat by $\mathrm{P} 4$ & $0.71008 \pm 0.00017$ \\
\hline ST_W_P21 & Water & 48.41908 & 16.8472 & Small stream by P10 & $0.70954 \pm 0.00017$ \\
\hline ST_W_P22 & Water & 48.44719 & 16.82752 & Krüttelbach & $0.70990 \pm 0.00017$ \\
\hline
\end{tabular}

Tab. 3. The $n\left({ }^{87} \mathrm{Sr}\right) / n\left({ }^{86} \mathrm{Sr}\right)$ ratios of all investigated recent environmental samples (soils and water), taken in a radius of five kilometres around Stillfried/March. Error bars correspond to expanded uncertainty $U(k=2)$.

Hence, in the present study, a local environmental Sr range has been established based on the Sr isotope ratio ranges derived from soil and water samples taking account of the following considerations: i) secondary anthropogenic impact such as from fertilizer might hamper the determination of representative $\mathrm{Sr}$ isotopic compositions; ${ }^{109}$ ii) a local $\mathrm{Sr}$ isotopic signature derived from soil extracts does not always match with $n\left({ }^{87} \mathrm{Sr}\right) / n\left({ }^{86} \mathrm{Sr}\right)$ signatures measured in vertebrate and human body tissue, since their $\mathrm{Sr}$ originates from different sources with different, diet-dependent amounts. ${ }^{110}$ Nevertheless, Sr signatures of plants are more likely to be representative for the local biosphere Sr values compared to the extractable Sr fraction of soils. ${ }^{111}$ Due to the limited number of recent and prehistoric vegetation remains in the present study, we used the extractable Sr from

109 Maurer et al. 2012.

110 LENGFELDER et al. 2019.

111 Maurer et al. 2012. - Ryan et al. 2018. recent soils and water to determine the local environmental Sr range of the hillfort site at Stillfried/March. The local environmental Sr range is seen as an indicator for an autochthonous Sr signal and a reasonable proxy for capturing the variability of Sr isotopic signals in the local environment of Stillfried/March.

Further, in the present study, an autochthonous Sr range has been established to estimate the Sr fraction, which is taken up via the food chain. In this, a simplified approach from the concept of mixing models ${ }^{112}$ has been applied. It combined different sources representing bioavailable $\mathrm{Sr}$ (Sr that can potentially be taken up by living organisms) in nutrition supplies (food/water) of the habitat under investigation, taking account of the following considerations: in general, the preservation of archaeological foodstuff (e.g., vegetation remains) and beverages supplies are crucial, and in most archaeological contexts are only preserved to

112 Lengfelder et al. 2019. 
a limited extent. In the case of the hillfort site at Stillfried/ March, nutrition supplies were not available for the $\mathrm{Sr}$ isotopic analysis. In the absence of such objects, the autochthonous $n\left({ }^{87} \mathrm{Sr}\right) / n\left({ }^{86} \mathrm{Sr}\right)$ signature can be estimated making use of presumably local (archaeological) faunal remains, ${ }^{113}$ assuming that they have mainly incorporated the local bioavailable $\mathrm{Sr},{ }^{114}$ or making use of dentine Sr values from a residential human population. ${ }^{115}$ In the previous study by Teschler-Nicola et al., the autochthonous $n\left({ }^{87} \mathrm{Sr}\right) / n\left({ }^{86} \mathrm{Sr}\right)$ range was defined as the mean human dentine $n\left({ }^{87} \mathrm{Sr}\right) / n\left({ }^{86} \mathrm{Sr}\right)$ plus or minus four times the standard deviation. ${ }^{116}$ The autochthonous Sr range thus determined exceeds the autochthonous Sr range of the hillfort site at Stillfried/March in the present study. A previous study has observed that modern animals (especially domesticated animals) may have $\mathrm{Sr}$ sources different to local sources, and archaeological animal dentine is more generally subject to the vagaries of contamination or diagenesis. ${ }^{117}$ Hence, only enamel from residual animals which fed locally in the same area as the humans ${ }^{118}$ have been considered to generate a representative autochthonous Sr signal for the hillfort site at Stillfried/March. ${ }^{119}$ In this, the $n\left({ }^{87} \mathrm{Sr}\right) / n\left({ }^{86} \mathrm{Sr}\right)$ signature of the recommended residential large vertebrates and omnivores ${ }^{120}$ and domesticated animals (dogs and pigs) is in agreement with prehistoric plants (Fig. 13) used as a proxy for the Sr source in vegetation like vegetables. The fractional contribution of animal products itself is negligible. ${ }^{121}$ The overlap of the modern local water range and prehistoric mussel samples has been taken as a representative source of Sr for drinking water. Based on that, the autochthonous $n\left({ }^{87} \mathrm{Sr}\right) / n\left({ }^{86} \mathrm{Sr}\right)$ range presented is seen as a more defined range in comparison to Teschler-Nicola et al. ${ }^{122}$

113 E.g. Grupe et al. 1997. - Price, Burton, Bentley 2002. - BentLey, KnipPer 2005. - Maurer et al. 2012.

114 LENGFELDER et al. 2019.

115 E.g. Budd et al. 2000. - Schweissing, Grupe 2003. - Price et al. 2004. - Irrgeher et al. 2012. - KNIPPER et al. 2012. - TeschlerNicola, Irrgeher, Prohaska 2016.

116 Teschler-Nicola, Irrgeher, Prohaska 2016.

117 Copeland et al. 2010.

118 Blum et al. 2000. - Price, Burton, Bentley 2002. - Maurer et al. 2012.

119 Trade, exchange of animals or animal products as well as unknown nutrition habits and preferences might hamper the determination of an autochthonous signal.

120 Price, Burton, Bentley 2002. - Bentley 2006. - Lengfelder et al. 2019.

121 Knipper et al. 2012. - Lengfelder et al. 2019.

122 Teschler-Nicola, Irrgeher, Prohaska 2016.

\subsection{Sr Isotope Signals in Human Remains}

\subsubsection{Stillfried Settlement Pit V1141}

The $n\left({ }^{87} \mathrm{Sr}\right) / n\left({ }^{86} \mathrm{Sr}\right)$ ratios of individuals from Pit V1141 have previously been analysed. ${ }^{123}$ Comparing the results of Teschler-Nicola et al. ${ }^{124}$ with the present study, the enamel data are in good agreement. Slightly differing $n\left({ }^{87} \mathrm{Sr}\right) / n\left({ }^{86} \mathrm{Sr}\right)$ ratios are observed for the measured dentine values.

The determined Sr signatures of the enamel of SK 1 (sign. 9023) from both studies overlap within uncertainties (Tab. 1). Regardless of the fact that the two studies used different teeth reflecting different stages in an individual's life, ${ }^{125}$ neither the enamel of the first molar (M1) nor that of the first premolar (PM1) of SK 1 lies within the local environmental and autochthonous Sr ranges. This means that the classification of SK 1 as an allochthonous individual is supported by both datasets. On the other hand, the isotope signals in (primary) dentine diverge in their values. The signatures of the (primary) dentine of SK 1 from the two studies do not overlap within their uncertainties. While the ratio of M1 lies within the local environmental and autochthonous Sr ranges, the ratio of PM1 does not. In the case of M1, the sampled mixture of root and pulp dentine of the previous study ${ }^{126}$ contains $82 \% \pm 12 \%$ diagenetic $\mathrm{Sr}$, which points towards an overlap with the local environmental and autochthonous Sr ranges, since root dentine is more likely to be exposed to diagenesis. In the case of PM1, where circumpulpal primary dentine has been sampled in the present study, a portion of $13 \% \pm 2 \%$ diagenetic Sr has been calculated. In agreement with previous studies, ${ }^{127}$ it is expected that circumpulpal primary dentine is less affected by diagenesis.

The measured $n\left({ }^{87} \mathrm{Sr}\right) / n\left({ }^{86} \mathrm{Sr}\right)$ ratios of enamel and primary dentine of SK 4 (sign. 9026) determined by Teschler-Nicola et al. ${ }^{128}$ and this study overlap within their uncertainties (Tab. 1). This finding supports the classification of individual SK 4 as an supposedly autochthonous individual.

Within the present study, only two out of the seven individuals from Pit V1141 were re-investigated based on the more sophisticated approach, which took the effect of diagenetic changes in dentine into account. These results, speaking generally and with a degree of caution, do not contradict the results obtained by a former pilot study of $n\left({ }^{87} \mathrm{Sr}\right) / n\left({ }^{86} \mathrm{Sr}\right)$ ratios, which included all seven skeletons deposited in this pit. Some scholars suggest that the remains

123 Teschler-Nicola, Irrgeher, Prohaska 2016.

124 Teschler-Nicola, Irrgeher, Prohaska 2016.

125 Hillson 1996. - AlQahtani, Hector, Liversidge 2010.

126 Teschler-Nicola, Irrgeher, Prohaska 2016.

127 Bell, Boyde, Jones 1991.

128 Teschler-Nicola, Irrgeher, Prohaska 2016. 
probably stem from members of a 'big family', ${ }^{129}$ representing an 'exceptional social position', a 'dynasty', etc. ${ }^{130}$ Nevertheless, the variability of the $n\left({ }^{87} \mathrm{Sr}\right) / n\left({ }^{86} \mathrm{Sr}\right)$ signals obtained by the pilot study was unexpected - four individuals showed signatures above the signal of the location (SK $1,{ }^{131}$ SK 5, SK 6 and SK 7), ${ }^{132}$ two are within the range (SK 2 and SK 4), and one showed a lower value (SK 3). A detail, probably of interest for further studies, is the fact, that two of the (purported local) infants (SK 2 and SK 4) shared some similarity with the (purported local) female SK 3, whereas the other two infants (SK 6 and SK 7) shared some similarity in their $n\left({ }^{87} \mathrm{Sr}\right) / n\left({ }^{86} \mathrm{Sr}\right)$ signals with the female SK 5 . The ratios of the latter are above the local geological fingerprint signals of the Stillfried site, implying non-local origins or a change of residence.

Another question concerned the relationship between the depositional strata and the provenance of the individuals buried in a non-standard manner in Pit V1141. Based on the precise descriptions and documentary evidence of the findings, two skeletal layers are obvious. Layer 1, the deepest layer of the skeletal remains included four individuals (SK 1, SK 4, SK 5 and SK 6). Three of them, the male (SK 1), the older female (SK 5), and the 6-year-old child (SK 6) are non-locals (allochthonous; their values lie above the geological fingerprint of the Stillfried area; probably matching the area of the Bohemian Massif $\left.{ }^{133}\right)$. The $n\left({ }^{87} \mathrm{Sr}\right) / n\left({ }^{86} \mathrm{Sr}\right)$ signals of SK 1 and SK 4 were confirmed by the present study. Layer 2 is an assemblage of the remains of three individuals (SK 2, SK 3, and SK 7); here, only the $n\left({ }^{87} \mathrm{Sr}\right) / n\left({ }^{86} \mathrm{Sr}\right.$ ) isotope signal of individual SK 2 is in accordance with the local signal; SK 3's signal is below and SK 7's above the local Sr isotope range. This heterogeneity, which appears not only in the individuals buried in a deviant manner in both layers of Pit V1141, is a structural condition that obviously characterizes Pit V841 in an analogous manner as well.

We will leave open the question of whether, and if so why, the finding positions of the human remains (e.g., the dominant position of SK 1 in the centre of the pit in an extended supine position, while the other six individuals

129 Breitinger 1980. - Szilvássy, Kritscher, Hauser 1988, 70. 130 Eibner 1980, 132-135. - EibNER 1988, 84-86.

131 Signatures see Tab. 1.

132 The bioavailable Sr signature of the Stillfried location was identified by using recent soil samples.

133 The Austrian part of the Bohemian Massif shares the Moldanubian unit and the Moravian unit, which consists predominantly of granite, granulite, granitoids and gneiss: FriedL et al. 2004. - The $n\left({ }^{87} \mathrm{Sr}\right) / n\left({ }^{86} \mathrm{Sr}\right)$ ratios within this unit display values up to 0.770 : Janoušek, Rogers, Bowes 1995. - VRÁnA, JanoušEk 1999. JANOUŠEK et al. 2004. share the southern pit edge), which were documented in detail and often (controversially discussed), relate to their provenance. Nonetheless, there is one peculiar feature that may attract interest. Figure 2 shows that the corpses were deposited differently; some seem to be laid down carefully (e.g., the 45-year-old female SK 5 and the 6-year-old boy SK 6), whereas one was - with high probability - rashly thrown into the cavity (the 3-year-old boy SK 2). Their $n\left({ }^{87} \mathrm{Sr}\right) / n\left({ }^{86} \mathrm{Sr}\right)$ isotope values show that there is no association between a particular 'ritual' and the provenance of the individuals: SK 5 and SK 6, for example, were deposited carefully and in close physical contact; both are identified as non-locals. On the other hand, the two individuals SK 1 and SK 2, characterized by their accidental position caused by a rash throwing down of the corpses, are of non-local (SK 1) and local origin (SK 2). ${ }^{134}$

To verify these few 'similarities' of provenance by using the geological fingerprinting and to verify the conflicting genealogical pedigree reconstructions of the seven individuals deposited in Pit V1141 of Stillfried/March, that were carried out earlier, ${ }^{135}$ we used the mitochondrial (mt) DNA analysis ${ }^{136}$ as a further approach to highlight the matrilineal relationship. As stated by Walther Parson et al., the (mt)DNA test did "not corroborate any of the [pedigree] models" suggested. ${ }^{137}$ Conspicuously, two individuals, SK 5, the 45-year-old female, and SK 6, the 6-year-old boy, not only showed the same Haplogroup (H5) and the same mitotypes. They were also buried in close physical relation and show $n\left({ }^{87} \mathrm{Sr}\right) / n\left({ }^{86} \mathrm{Sr}\right)$ isotope values above the local range of Stillfried, implying similar provenance. This seems to confirm the hypothesis of a "female protecting her son (or a close maternal relative)" ${ }^{138}$ All the other individuals yielded different mitotypes implying that they were maternally unrelated. However, all these approaches are limited, as they cannot decode the social-emotional ties that linked this group of people when they met the same fate.

\subsubsection{Stillfried Settlement Pit V1133}

The difference in the Sr fingerprint of enamel and primary dentine of the child whose calvarium was found in Pit V1133 could be the result of either diagenetic alteration, a change in nutrition or in food supply, or a change of residence from an area with a similar $n\left({ }^{87} \mathrm{Sr}\right) / n\left({ }^{86} \mathrm{Sr}\right)$ ratio.

134 Teschler-Nicola, Irrgeher, Prohaska 2016, Fig. 5. 135 Breitinger 1980. - Szilvássy, Kritscher, Hauser 1988.

136 PARson et al. 2018.

137 PArson et al. 2018, 150.

138 Parson et al. 2018, 150. 


\subsubsection{Stillfried Settlement Pit V841}

SK 4 (sign. 9044) and SK 8 (sign. 9049) display similar allochthonous enamel $n\left({ }^{87} \mathrm{Sr}\right) / n\left({ }^{86} \mathrm{Sr}\right)$ ratios (Tab. 1$)$ and could therefore originate from the same or a geologically similar region, probably from the area of the Bohemian Massif (similar to SK 1 from Pit V1141).

The enamel $n\left({ }^{87} \mathrm{Sr}\right) / n\left({ }^{86} \mathrm{Sr}\right)$ ratios of SK $10($ sign. 9051$)$ and in particular SK 2 (sign. 9042) are different from the ratios of the other autochthonous and allochthonous individuals even though they are still within the local environmental Sr range but below the autochthonous range. This could be the result of a different source of food compared to the other individuals during childhood. Alternatively, the individual lived in another area with a similar $n\left({ }^{87} \mathrm{Sr}\right) / n\left({ }^{86} \mathrm{Sr}\right)$ signature to the local environmental range of Stillfried/March. Based on the autochthonous Sr range, determined in particular from residual and domesticated animals, potential drinking water sources and archaeological plants, which represents most closely the autochthonous human $n\left({ }^{87} \mathrm{Sr}\right) / n\left({ }^{86} \mathrm{Sr}\right) \mathrm{ra}-$ tio of the hillfort site at Stillfried/March, the latter seems to be more likely. This would also classify SK 10 and SK 2 as allochthonous individuals of the hillfort site at Stillfried/ March, who were nevertheless born and raised nearby.

The variation in the enamel and primary dentine $n\left({ }^{87} \mathrm{Sr}\right) / n\left({ }^{86} \mathrm{Sr}\right)$ ratio of SK 13 could be the result of either diagenetic alterations, a change in nutrition or a change in the source of food, as in the case of the child from Pit V1133.

\subsubsection{Archaeological and Bioanthropological Interpretation of the Skeletal Depositions}

All three findings (V841, V1133, V1141) were excavated on the highest and most heavily fortified area of the site, situated strikingly close to the prehistoric rampart. The human depositions were therefore most likely located in a public and/or well-controlled area. Secret criminal actions are therefore more likely to be excluded. In addition, V1141 was found in the range of the presumed former residence of the leadership (the so-called 'Kirchhügel').

Furthermore, the individuals from V1141 are of greater body height than the average ${ }^{139}$ - a phenomenon sufficiently documented by many recent population studies and correlated with socio-economic circumstances and higher social affiliation - and presumably less often affected by inflammations than the individuals from Pits V841 and V1133. ${ }^{140}$ These findings imply that the individuals from Pit V1141 may belong to a higher social class; but such a conclusion is weak and currently highly speculative due to

139 BREITINGER 1980, 61-62.

140 See sections 1.2.2 and 1.2.3. the very small sample size and the inconsistent recording systems used for the documentation of the stress markers. Further, it should be mentioned that the results of the Sr isotopic analysis of this study (V841, V1133) and the previous study (V1141) ${ }^{141}$ are not able to support such an assumption as the deposited individuals of both groups comprise an identical frequency of supposedly autochthonous ( 50\%) and allochthonous individuals ( $50 \%)$.

The stratigraphy of the depositions in V841 proves diverse activities in view of settlement burials. Some patterns are observable within the individual skeletal layers: complete corpses were put down in layer 1; in layers 2 and 3 complete and incomplete bodies were deposited. With caution, due to the small number of samples, the Sr isotopic data might indicate that layer 1 of V841 is dominated by autochthonous individuals, while layers $2-4$ contain at least one allochthonous individual. In order to explore differences between the various layers of V841, future studies must include the total number of human remains recovered. Four of the five skeletons of skeletal layer 3 show the bite marks of carnivores. These multi-phased events recognizable for V841 seem to run parallel to those of V1141 and reflect a different treatment of the deceased. Furthermore, the incomplete human skeletons and single human bones recovered at the Stillfried site - including single calvaria - indicate that decay of the corpses started in another location. These various ways of dealing with dead bodies are well known in Late Bronze Age central Europe (see section 1.2).

Pit V1133, for example, contained a child's calvarium, which exhibits several (deadly) fractures as a result of blunt force trauma. ${ }^{142}$ Referring to the interpretation of similar finds from the comparable fortified site of the Late Urnfield Culture settlement 'Wasserburg Buchau' (Baden Württemberg, Germany), ${ }^{143}$ it is possible that the Stillfried child was killed in a similar ritual act during the first phase of the rampart. At the 'Wasserburg Buchau' site the skulls or parts of skulls of five children with traces of injuries were recorded. The skulls were found in close proximity to the annular wooden fortification and interpreted as sacrifices. ${ }^{144}$ Two individuals, identified as a boy (no. S4) and as a girl (no. IP6), died at an age of 7-8 years. These children were

141 Teschler-Nicola, Irrgeher, Prohaska 2016.

142 Eibner 1976. - Griebl, Hellerschmid 2013, 331-332. - Typically fractures in the area of the foramen magnum indicate that the blows hit the head while the child was in an upright position: Teschler-Nicola, Irrgeher, Prohaska 2016, 162 and footnote 2. - Hellerschmid, Griebl in prep.

143 Baumeister, Menninger, Trautmann 2009. - Trautmann, Wahl 2009. - Trautmann, Trautmann, Baumeister 2012. 144 Trautmann, Trautmann, Baumeister 2012, 33-34. 
most likely related to each other and the profiles of the $\mathrm{Sr}$ isotopes suggest a local origin for both individuals. ${ }^{145}$ Interestingly, local origin has also been proven for the child from Stillfried V1133.

\subsubsection{Stillfried in the Context of Human Migration Studies from the Bronze Age in Europe}

Previous studies of the Early Bronze Age in central and western Europe reported no or low portions of non-local individuals of up to some $20 \%$ at the individual sites based on $\mathrm{Sr}$ isotopic analysis. ${ }^{146}$ In their study, Corina Knipper et al. ${ }^{147}$ tested the archaeological hypotheses whether the deviant burials (incl. settlement pits) of the Early Bronze Age (Únětice Culture) represented socially distinct or non-local individuals. They found no indications for higher proportions of non-local individuals among inhumations in rectangular or settlement pits.

By contrast, Sr isotope studies of Late Bronze Age (Urnfield culture, Hallstatt A1 period) skeletal populations revealed a slightly higher proportion of non-locals of almost one-third of the adults from inhumations at e.g., Neckarsulm $^{148}$ in southwestern Germany; moreover, it became apparent that local residents dominated the single graves (approx. $50 \%$ ), while only $25 \%$ of non-locals had been buried in single graves. Interesting results were yielded by the study carried out by Claudio Cavazzuti et al. ${ }^{149}$ on the skeletal remains of a Late Bronze Age population from Frattesina, in northern Italy, a site that was also identified as a 'central site' or 'port of trade'. The authors identified 'flows of people' there, an outcome that seems to be - carefully interpreted due to the small sample size-consistent with the results we obtained for the Stillfried settlement.

Overall, two out of the five analysed adults (incl. previous study ${ }^{150}$ ) from two settlement pits in Stillfried were classified as allochthonous individuals based on Sr isotopic information. Even though the proportion of allochthonous adult individuals may be skewed by the small sample sizes and sample selection, it shows a similar trend as the previous study from south-western Germany, where almost onethird of the adults individuals from inhumations were classified as non-local individuals. ${ }^{151}$

145 Stephan 2009. - Trautmann, Trautmann, Baumeister 2012, 26-27.

146 Evans, Chenery, Fitzpatrick 2006. - Kreutz 2011. - Oelze, Nehlich, Richards 2012. - KNipPer et al. 2016.

147 KNIPPER et al. 2016.

148 WAHL, Price 2013.

149 Cavazzuti et al. 2019.

150 Teschler-Nicola, Irrgeher, Prohaska 2016.

151 WAHL, PRICE 2013.
Six out of the eleven analysed subadult individuals (incl. previous study ${ }^{152}$ ) from the settlement pits in Stillfried were classified as allochthonous individuals based on Sr isotopic information. Two of these allochthonous subadults might still have been born and raised nearby (see section 4.2.3). Nonetheless, this is a fairly high proportion for subadults, who can be expected to be less mobile than adults in settled societies. ${ }^{153}$ Therefore, these results are unexpected, and may imply either a rising/growing population or a common historical phenomenon of young foreign workers. To prove such an assumption it would be helpful to include the whole sample of subadults, focusing on the younger children (Infans I) for comparative reasons.

Overall, there is no clear indication that the inhumations in settlement pits represent a distinct group of the Late Bronze Age society at the Stillfried settlement, which is distinguished by a higher or lower percentage of allochthonous individuals. Again, in order to clarify the picture, future studies must include the total number of human remains recovered from the settlement pits as well as a representative sample of cremated remains from the Stillfried site.

\subsection{Sr in Primary Dentine - Diagenetic Challenge and Potential}

Apart from the identification of allochthony and supposed autochthony based on Sr isotopic signatures in human enamel, a mathematical approach has been tested in order to correct the $\mathrm{Sr}$ isotope ratios in human primary dentine for diagenetic alteration considering a diagenetic Sr proportion and the Sr isotopic composition of the repository material (see section 2.2.2). When using Sr mass fractions of human enamel to calculate the diagenetic proportion of primary dentine, one might argue that with residual changes the Sr mass fraction might change too. But in the approach presented here, the calculated uncertainty for Sr isotopic ratios of the biogenic human primary dentine covers small changes in the estimated biogenic Sr signatures in the Sr mass fraction of the enamel.

In the case of the five allochthonous individuals ${ }^{154}$ from the hillfort site at Stillfried, the mathematical approach has revealed estimated biogenic $n\left({ }^{87} \mathrm{Sr}\right) / n\left({ }^{86} \mathrm{Sr}\right)$ ratios for the primary dentine that are significantly different from their enamel Sr signature. Except for individual SK 4 (sign. 9044) from Pit V841, the estimated biogenic $n\left({ }^{87} \mathrm{Sr}\right) / n\left({ }^{86} \mathrm{Sr}\right)$ ratios for the primary dentine overlap within uncertainties with

152 Teschler-Nicola, Irrgeher, Prohaska 2016.

153 KNIPPER et al. 2016.

154 V841: SK 2/sign. 9042, SK 4/sign. 9044, SK 8/sign. 9049, SK 10/ sign. 9051; V1141: SK 1/sign. 9023. 
the measured (diagenetic) Sr value of the primary dentine (Fig. 14). It is noticeable that individuals SK 4 (sign. 9044) from Pit V841 and SK 1 (sign. 9023) from Pit V1141 reveal higher estimated biogenic Sr isotope ratios in the primary dentine compared to the rest of the investigated population, which do not overlap with the local environmental and autochthonous Sr range. Further, when comparing the estimated biogenic $n\left({ }^{87} \mathrm{Sr}\right) / n\left({ }^{86} \mathrm{Sr}\right)$ ratios of primary dentine of SK 1 in the study by Teschler-Nicola et al. ${ }^{155}$ and this study (M1: $0.71181 \pm 0.00106$, PM1: $0.71161 \pm 0.00031$, Tab. 1), the values overlap within uncertainties, indicating no differences between the two studies.

The life span of an individual potentially preserved in its dentine, e.g., as an elemental finger print or (biogenic) Sr isotopic signature, is subject to discussion. The formation period of human dentine differs significantly from that of human enamel, for example, the incremental growth of human first premolar enamel starts formation at 2.5 years of age and continues until completion at 6.5 years of age, whereas human first premolar primary dentine continues formation at least until the apical closure of the tooth root ${ }^{156}$ at 14.5 years of age. ${ }^{157}$ In his textbook on oral histology Antonio Nanci has stated that once formed during adolescence and early adulthood, human primary dentine does not remodel and undergo significant metabolic or structural changes. On the downside, the odontoblasts lining the pulp chamber of human primary dentine retain the ability to produce new dentine throughout life, ${ }^{158}$ and human secondary and tertiary dentine forms throughout our lifetime. ${ }^{159}$ This leaves unsolved and challenging questions about structural changes in dentine during an individual's life. Further, a limited number of studies indicate potential regeneration and remodelling of dentine layers, providing information about the elemental and isotopic composition related to more recent exposure/uptake. ${ }^{160}$

\section{Conclusion}

This contribution provides new data about the possible origins of individuals from deviant burials in settlement pits of the Late Bronze Age site Stillfried/March, Lower Austria. For that purpose we calculated a local environmental Sr range from recent environmental samples, which was further narrowed down to an autochthonous Sr range using prehistoric faunal (incl. mussels) and plant remains.

155 Teschler-Nicola, Irrgeher, Prohaska 2016.

156 Arana-Chavez, Massa 2004.

157 AlQahtani, Hector, Liversidge 2010.

158 NANCI 2013.

159 Shepherd et al. 2012. - Beaumont et al. 2015.

160 Castro et al. 2010. - Fortes et al. 2015.
By means of the latter approach, we derived an isotopic signature of bioavailable $\mathrm{Sr}$ from dietary sources that were taken by the Late Bronze Age residents of Stillfried. Based on a careful consideration of a representative autochthonous Sr range, we identified five individuals from Pits V841 and V1141 as allochthonous individuals, while the remaining six individuals most likely represented autochthonous individuals. The sample investigated included adults (male and females) and subadults. Neither a chronological nor a layer coherency concerning the isotope signatures of the deposited individuals could be observed. This 'similar treatment' of the deceased along with an atypical burial practice corroborates the assumption that this pattern of high mobility matches the structure of the local/autochthonous population and probably reflects - based on the diversity of the individuals origin - even the structure of a 'central site' with a wide catchment area. Given the rarity of provenance studies in respect of this period which are probably biased by the specific cultural tradition of cremation burial, the outcome of this study is also of paramount relevance in the wider context of the European Late Bronze Age.

\section{Acknowledgements}

This work was funded by the Austrian Science Fund (FWF): P28005 - 'Resource management, power and cult in Stillfried?' and by the Chemical Monthly fellowship of the Austrian Academy of Sciences (ÖAW). The authors would like to pay tribute to Irene Petschko from the Institute for Oriental and European Archaeology and Stephan Tikatsch for processing the illustrations of the archaeological part of this contribution. Also, we would like to thank Bernhard Weinzinger from the Natural History Museum Vienna for his input on the sample preparation of archaeological human teeth. Furthermore, we would like to thank Felix Köstelbauer for his support with ArcGIS®. Finally, thanks to Melanie Diesner and Tine Opper from the VIRIS group at BOKU for their support in the lab.

\section{References}

\section{ADÁMEK 1961}

F. AdÁmek, Pravěké hradisko u Obran. Monografické Práce Moravského Muzea v Brně, Brno 1961.

AlQahtani, Hector, Liversidge 2010

S. J. AlQahtani, M. P. Hector, H. M. Liversidge, Brief communication: the London atlas of human tooth development and eruption, American Journal of Physical Anthropology 142, 2010, 481-490.

Arana-Chavez, Massa 2004

V. E. Arana-Chavez, L. F. Massa, Odontoblasts: the cells forming and maintaining dentine, The International Journal of Biochemistry \& Cell Biology 36, 2004, 1367-1373.

Aspöck 2013

E. Aspöck, Über die Variabilität von Totenpraktiken oder: Probleme einer dichotomen Auffassung von Toten- bzw. Bestattungsbrauchtum. In: N. Müller-Scheessel (Ed.), ,Irreguläre‘ Bestattungen in der Urgeschichte: Norm, Ritual, Strafe ...? Akten der Internationalen Tagung in Frankfurt a. M. vom 3. bis 
5. Februar 2012. Kolloquien zur Vor- und Frühgeschichte 19, Bonn 2013, 25-38.

BALFANZ, JARECKI 2004

K. Balfanz, H. Jarecki, Jung- und spätbronzezeitliche Sonderbestattungen in Mitteldeutschland: Quellen und Fragestellungen, Jahresschrift für mitteldeutsche Vorgeschichte 88, 2004, 339-378.

Bataille, Bowen 2012

C. P. Bataille, G. J. Bowen, Mapping ${ }^{87} \mathrm{Sr} /{ }^{86} \mathrm{Sr}$ variations in bedrock and water for large scale provenance studies, Chemical Geology 304-305, 2012, 39-52.

Baumeister, Menninger, Trautmann 2009

R. Baumeister, M. Menninger, I. Trautmann, Totschlag, Überfall oder Menschenopfer? In: R. Baumeister (Ed.), Mord im Moor? Die Bronzezeit am Federsee im Spiegel von Archäologie und Naturwissenschaft (Exhibition catalogue, Bad Buchau 2009). Bad Buchau 2009, 81-87.

BEAUMONT et al. 2015

J. Beaumont, J. Montgomery, J. Buckberry, M. Jay, Infant mortality and isotopic complexity: new approaches to stress, maternal health, and weaning, American Journal of Physical Anthropology 157, 2015, 441-457.

BeLl, BOYde, JONES 1991

L. S. Bell, A. Boyde, S. J. Jones, Diagenetic alteration to teeth in situ illustrated by backscattered electron imaging, Scanning 13, 1991, 173-183.

BENSON et al. 2013

A. Benson, L. Kinsley, M. Willmes, A. Defleur, H. Kokkonen, M. Mussi, R. GRÜN, Laser ablation depth profiling of U-series and Sr isotopes in human fossils, Journal of Archaeological Science 40, 2013, 2991-3000.

BeNTLEY 2006

A. R. BENTLEY, Strontium isotopes from the earth to the archaeological skeleton: a review, Journal of Archaeological Method and Theory 13, 2006, 135-187.

Bentley, Knipper 2005

R. A. Bentley, C. Knipper, Geographical patterns in biologically available strontium, carbon and oxygen isotope signatures in prehistoric SW Germany, Archaeometry 47, 2005, 629-644.

BLum et al. 2000

J. D. Blum, E. H. Taliaferro, M. T. Weisse, R. T. Holmes, Changes in $\mathrm{Sr} / \mathrm{Ca}, \mathrm{Ba} / \mathrm{Ca}$ and ${ }^{87} \mathrm{Sr} /{ }^{86} \mathrm{Sr}$ ratios between two forest ecosystems in the northeastern USA, Biogeochemistry 49, 2000, 87-101.

BREITINGER 1976

E. BREITINGER, Das Kalvarium unter dem späturnenfelderzeitlichen Wall von Stillfried an der March, Forschungen in Stillfried 2, 1976, 86-100.

BREITINGER 1980

E. BReitinger, Skelette aus einer späturnenfelderzeitlichen Speichergrube in der Wallburg von Stillfried an der March, NÖ, Forschungen in Stillfried 4, 1980, 46-106.

Budd et al. 2000

P. Budd, J. Montgomery, B. Barreiro, R. G. Thomas, Differential diagenesis of strontium in archaeological human dental tissues, Applied Geochemistry 15, 2000, 687-694.

Capo, Stewart, Chadwick 1998

R. C. Capo, B. W. Stewart, O. A. Chadwick, Strontium isotopes as tracers of ecosystem processes: theory and methods, Geoderma 82, 1998, 197-225.
CASTro et al. 2010

W. Castro, J. Hoogewerff, C. Latkoczy, J. R. Almirall, Application of laser ablation (LA-ICP-SF-MS) for the elemental analysis of bone and teeth samples for discrimination purposes, Forensic Science International 195, 2010, 17-27.

Cavazzuti et al. 2019

C. Cavazzuti, R. Skeates, A. R. Millakd, G. Nowell, J. Peterkin, M. Bernabò Brea, A. Cardarelli, L. Salzani, Flows of people in villages and large centres in Bronze Age Italy through strontium and oxygen isotopes, PloS ONE 14, 2019, e0209693. doi: 10.1371/journal.pone.0209693.

Chiaradia, Gallay, Todt 2003

M. Chiaradia, A. Gallay, W. Todt, Different contamination styles of prehistoric human teeth at a Swiss necropolis (Sion, Valais) inferred from lead and strontium isotopes, Applied Geochemistry 18, 2003, 353-370.

Copeland et al. 2010

S. R. Copeland, M. Sponheimer, J. A. Lee-Thorp, P. J. Le Roux, D. J. De Ruiter, M. P. Richards, Strontium isotope ratios in fossil teeth from South Africa: assessing laser ablation MC-ICPMS analysis and the extent of diagenesis, Journal of Archaeological Science 37, 2010, 1437-1446.

Coplen 2011

T. B. Coplen, Guidelines and recommended terms for expression of stable-isotope-ratio and gas-ratio measurement results, Rapid Communications in Mass Spectrometry 25, 2011, 2538-2560.

Dauphin, Williams 2004

Y. Dauphin, C. T. Williams, Diagenetic trends of dental tissues, Comptes Rendus Palevol 3, 2004, 583-590.

Driessens, VerbeECK 1990

F. C. M. Driessens, R. K. Verbeeck, Biomaterials. Boca Raton Ann Arbor - Boston 1990.

DudÁs et al. 2016

F. Ö. Dudás, S. A. LeBlanc, S. W. Carter, S. A. Bowring, Pb and $\mathrm{Sr}$ concentrations and isotopic compositions in prehistoric North American teeth: a methodological study, Chemical Geology 429, 2016, 21-32.

EIBNER 1976

C. EIBNer, Eine späturnenfelderzeitliche Grube unter den Aufschüttungen des Westwalles von Stillfried: Zum Befund einer Schädeldeposition, Forschungen in Stillfried 2, 1976, 70-85.

EIBNER 1980

C. Eibner, Die Mehrfachbestattung aus einer Grube unter dem urnenfelderzeitlichen Wall in Stillfried an der March, NÖ, Forschungen in Stillfried 4, 1980, 107-142.

EIBNER 1988

C. Eibner, Die Mehrfachbestattung aus Stillfried aus archäologischer Sicht. In: F. Felgenhauer, J. Szilvássy, H. Kritscher, G. Hauser (Eds.), Stillfried: Archäologie - Anthropologie. Veröffentlichungen des Museums für Ur- und Frühgeschichte Stillfried, Sonderband 3, Stillfried 1988, 77-86.

Evans, Chenery, Fitzpatrick 2006

J. A. Evans, C. A. Chenery, A. P. Fitzpatrick, Bronze Age childhood migration of individuals near Stonehenge, revealed by strontium and oxygen isotope tooth enamel analysis, Archaeometry 48, 2006, 309-321.

Evans et al. 2010

J. A. Evans, J. Montgomery, G. Wildman, N. Boulton, Spatial variations in biosphere ${ }^{87} \mathrm{Sr} /{ }^{86} \mathrm{Sr}$ in Britain, Journal of the Geological Society $167,2010,1-4$. 
Felgenhauer 1996

F. Felgenhauer, Stillfried: Lebensraum des Menschen seit 30.000 Jahren: Archäologischer Fundplatz von internationaler Bedeutung: Objekt interdisziplinärer Forschung von bedeutendem Rang: Ergebnisse der Ausgrabungen und Forschungen 19691989, Forschungen in Stillfried 9-10, 1996, 9-29.

Fergusson, Purchase 1987

J. E. Fergusson, N. G. Purchase, The analysis and levels of lead in human teeth: a review, Environmental Pollution 46, 1987, 11-44.

FORTES et al. 2015

F. J. Fortes, M. D. Perez-Carceles, A. Sibon, A. Luna, J. J. LASERNA, Spatial distribution analysis of strontium in human teeth by laser-induced breakdown spectroscopy: application to diagnosis of seawater drowning, International Journal of Legal Medicine 129, 2015, 807-813.

FriedL et al. 2004

G. Friedl, F. Finger, J.-L. Paquette, A. von Quadt, N. J. McNaughton, I. R. Fletcher, Pre-Variscan geological events in the Austrian part of the Bohemian Massif deduced from U-Pb zircon ages, International Journal of Earth Sciences 93, 2004, 802-823.

GRIEBL in prep.

M. Griebl, Menschenniederlegungen im urnenfelderzeitlichen Siedlungszusammenhang in Mitteleuropa unter besonderer Berücksichtigung der Menschendepositionen von Stillfried (Niederösterreich). In: I. Hellerschmid, M. Griebl, Die späturnenfelderzeitlichen Tier- und Menschenniederlegungen von Stillfried an der March und die Stratigraphie der Wallbefestigung. Mitteilungen der Prähistorischen Kommission, in preparation.

Griebl, Biederer in prep.

M. Griebl, B. Biederer, Die Speichergruben der späturnenfelderzeitlichen Wallanlage von Stillfried an der March: Von der Getreidelagerung bis zur profanen oder kultischen Verfüllung. Mitteilungen der Prähistorischen Kommission, in preparation.

Griebl, Hellerschmid 2013

M. Griebl, I. Hellerschmid, Menschenknochen und Menschenniederlegungen in Siedlungsgruben der befestigten Höhensiedlung von Stillfried an der March, Niederösterreich: Gängige Praxis der Totenbehandlung in der jüngeren Urnenfelderkultur? In: N. Müller-Scheessel (Ed.), ,Irreguläre‘ Bestattungen in der Urgeschichte: Norm, Ritual, Strafe ...? Akten der Internationalen Tagung in Frankfurt a. M. vom 3. bis 5. Februar 2012. Kolloquien zur Vor- und Frühgeschichte 19, Bonn 2013, 327-346.

Griebl, Hellerschmid 2015

M. Griebl, I. Hellerschmid, Arbeitsgrube und Kultgrube? Verfärbung V0479 der späturnenfelderzeitlichen Wallanlage von Stillfried, Niederösterreich, Archaeologia Austriaca 99, 2015, 179-201.

GrIEBL et al. 2017

M. Griebl, B. Biederer, T. Jachs, I. Petschko, Aktuelle Forschungen zu den Speichergruben auf der späturnenfelderzeitlichen Wallanlage von Stillfried an der March. In: F. Pieler, P. Trebsche (Eds.), Beiträge zum Tag der Niederösterreichischen Landesarchäologie 2017. Festschrift für Ernst Lauermann. Katalog des Niederösterreichischen Landesmuseums N.F. 541, Asparn/Zaya 2017, 195-206.

GRUPE 1998

G. GRUPE, "Archives of childhood" - the research potential of trace element analyses of ancient human dental enamel. In:
K. W. Alt, F. W. Rösing, M. Teschler-Nicola (Eds.), Dental Anthropology: Fundamentals, Limits and Prospects. Vienna 1998.

Grupe et al. 1997

G. Grupe, T. D. Price, P. Schroter, F. Sollner, C. M. JohnSON, B. L. BEARD, Mobility of Bell Beaker people revealed by strontium isotope ratios of tooth and bone: a study of southern Bavarian skeletal remains, Applied Geochemistry 12, 1997, 517-525.

Hellerschmid 2006

I. Hellerschmid, Die urnenfelder-/hallstattzeitliche Wallanlage von Stillfried an der March: Ergebnisse der Ausgrabungen 1969-1989 unter besonderer Berücksichtigung des Kulturwandels an der Epochengrenze Urnenfelder-/Hallstattkultur. Mitteilungen der Prähistorischen Kommission 63, Vienna 2006.

Hellerschmid 2015

I. Hellerschmid, Mord oder Opferung? Die Niederlegung der „Sieben“ in Grube V1141 am Kirchhügel von Stillfried, Archaeologia Austriaca 99, 2015, 203-231.

Hellerschmid, Griebl in prep.

I. Hellerschmid, M. Griebl mit Beiträgen von P. Aigner, A. Bauer, M. Brandl, M. Marschler, M. M. Martinez, E. Pucher, K. Wiltschke-Schrotta, Die späturnenfelderzeitlichen Tier- und Menschenniederlegungen von Stillfried an der March und die Stratigraphie der Wallbefestigung. Mitteilungen der Prähistorischen Kommission, in preparation.

Hillson 1996

S. Hillson, Dental Anthropology. Cambridge 1996.

Hoppe, Koch, Furutani 2003

K. A. Hoppe, P. L. Koch, T. T. Furutani, Assessing the preservation of biogenic strontium in fossil bones and tooth enamel, International Journal of Osteoarchaeology 13, 2003, 20-28.

Horsky, Irrgeher, Prohaska 2016

M. Horsky, J. Irrgeher, T. Prohaska, Evaluation strategies and uncertainty calculation of isotope amount ratios measured by MC ICP-MS on the example of Sr, Analytical and Bioanalytical Chemistry 408, 2016, 351-367.

ILON 1992

G. ILON, Keftiubarren ingot from an urn-grave culture settlement at Gór-Kápolnadomb (C. Vas), Acta Academiae Scientiarum Hungaricae 44, 1992, 239-259.

ILON 2001

G. ILON, Siedlungswesen und Bestattungssitten in Gór: Zum Übergang von der Urnenfelder- zur Hallstattzeit. In: A. LIPPERT (Ed.), Die Drau-, Mur- und Raab-Region im 1. vorchristlichen Jahrtausend. Akten des internationalen interdisziplinären Symposiums vom 26. bis 29. April 2000 in Bad Radkersburg. Universitätsforschungen zur Prähistorischen Archäologie 78, Bonn 2001, 243-267.

IRRGEHER et al. 2012

J. Irrgeher, M. Teschler-Nicola, K. Leutgeb, C. Weiss, D. Kern, T. Prohaska, Migration and mobility in the latest Neolithic of the Traisen Valley, Lower Austria: Sr isotope analysis. In: E. Kaiser, J. Burger, W. Schier (Eds.), Population Dynamics in Prehistory and Early History: New Approaches by Using Stable Isotopes and Genetics. Topoi - Berlin Studies of the Ancient World 5, Berlin - Boston 2012, 213-226. IRRGEHER et al. 2013

J. Irrgeher, T. Prohaska, R. E. Sturgeon, Z. Mester, L. Yang, Determination of strontium isotope amount ratios in biological tissues using MC-ICPMS, Analytical Methods 5, 2013, 1687. 
IRRGEHER et al. 2015

J. Irrgeher, J. Vogl, J. Santner, T. Prohaska, Measurement Strategies. In: T. Prohaska, J. Irrgeher, A. Zitek, N. Jakubowski (Eds.), Sector Field Mass Spectrometry for Elemental and Isotopic Analysis. Cambridge 2015, 126-151.

Janoušek, Rogers, Bowes 1995

V. Janoušek, G. Rogers, D. R. Bowes, Sr-Nd isotopic constraints on the petrogenesis of the Central Bohemian Pluton, Czech Republic, Geologische Rundschau 84, 1995, 520-534.

JANOUŠEK et al. 2004

V. Janoušek, F. Finger, M. RoberTs, J. FrÝDA, Deciphering the petrogenesis of deeply buried granites: whole-rock geochemical constraints on the origin of largely undepleted felsic granulites from the Moldanubian Zone of the Bohemian Massif, Earth and Environmental Science Transactions of the Royal Society of Edinburgh 95, 2004, 141-159.

KAMENov et al. 2018

G. D. Kamenov, E. M. Lofaro, G. Goad, J. Krigbaum, Trace elements in modern and archaeological human teeth: implications for human metal exposure and enamel diagenetic changes, Journal of Archaeological Science 99, 2018, 27-34.

Kaus 1984

M. Kaus, Das Gräberfeld der jüngeren Urnenfelderzeit von Stillfried an der March: Ergebnisse der Ausgrabungen 1975-1977, Forschungen in Stillfried 6, 1984, 1-208.

KNIPPER et al. 2012

C. Knipper, A.-F. Maurer, D. Peters, C. Meyer, M. Brauns, S. J. G. Galer, U. von Freeden, B. Schöne, H. Meller, K. W. Alt, Mobility in Thuringia or mobile Thuringians: a strontium isotope study from early medieval Central Germany. In: E. Kaiser, J. Burger, W. Schier (Eds.), Population Dynamics in Prehistory and Early History: New Approaches by Using Stable Isotopes and Genetics. Topoi - Berlin Studies of the Ancient World 5, Berlin - Boston 2012, 287-310.

KNIPPER et al. 2016

C. Knipper, M. Fragata, N. Nicklisch, A. Siebert, A. SZÉcsényiNagy, V. Hubensack, C. Metzner-Nebelsick, H. Meller, K. W. Alt, A distinct section of the early Bronze Age society? Stable isotope investigations of burials in settlement pits and multiple inhumations of the Únětice culture in central Germany, American Journal of Physical Anthropology 159, 2016, 496-516.

Koenig, Rogers, Trueman 2009

E. Koenig, R. R. Rogers, C. N. Trueman, Visualizing fossilization using laser ablation-inductively coupled plasma-mass spectrometry maps of trace elements in Late Cretaceous bones, Geology $37,2009,511-515$.

KOHLER-SCHNEIDER 2001

M. KoHLER-SchNeIDER, Verkohlte Kultur- und Wildpflanzenreste aus Stillfried an der March als Spiegel spätbronzezeitlicher Landwirtschaft im Weinviertel, Niederösterreich. Mitteilungen der Prähistorischen Kommission 37, Vienna 2001.

KoHn, Moses 2013

M. J. Kohn, R. J. Moses, Trace element diffusivities in bone rule out simple diffusive uptake during fossilization but explain in vivo uptake and release, Proceedings of the National Academy of Sciences 110, 2013, 419-424.

KoHn, SCHOENINGER, BARKer 1999

M. J. Kohn, M. J. Schoeninger, W. W. Barker, Altered states: effects of diagenesis on fossil tooth chemistry, Geochimica et Cosmochimica Acta 63, 1999, 2737-2747.
KOOTKER et al. 2016

L. M. Kootker, R. J. van Lanen, H. Kars, G. R. Davies, Strontium isoscapes in The Netherlands: spatial variations in ${ }^{87} \mathrm{Sr} /{ }^{86} \mathrm{Sr}$ as a proxy for palaeomobility, Journal of Archaeological Science, Reports 6, 2016, 1-13.

Kramchaninov, Chernyshev, Shatagin 2012

A. Y. Kramchaninov, I. V. Chernyshev, K. N. Shatagin, Isotope analysis of strontium by multicollector inductively-coupled plasma mass spectrometry: high-precision combined measurement of ${ }^{88} \mathrm{Sr} /{ }^{86} \mathrm{Sr}$ and ${ }^{87} \mathrm{Sr} /{ }^{86} \mathrm{Sr}$ isotope ratios, Journal of Analytical Chemistry 67, 2012, 1084-1092.

KreUtZ 2011

D. Kreutz, Elemental and Isotopic Analysis by (Multiple Collector) - Inductively Coupled Plasma Mass Spectrometry in $\mathrm{Hu}$ man Teeth from the Early Bronze Age Excavation Site Franzhausen I (Lower Austria) for the Investigation of Population Dynamics and Dietary Patterns. Master Thesis, University of Vienna 2011.

KYLE 1986

J. H. KYLE, Effect of post-burial contamination on the concentrations of major and minor elements in human bones and teeth the implications for palaeodietary research, Journal of Archaeological Science 13, 1986, 403-416.

Lee-Thorp, Sponheimer 2003

J. Lee-Thorp, M. Sponheimer, Three case studies used to reassess the reliability of fossil bone and enamel isotope signals for paleodietary studies, Journal of Anthropological Archaeology 22, 2003, 208-216.

LENGFELDER et al. 2019

F. Lengfelder, G. Grupe, A. Stallauer, R. Huth, F. Sollner, Modelling strontium isotopes in past biospheres - assessment of bioavailable $\left.{ }^{87}\right) \mathrm{Sr} /\left({ }^{86}\right) \mathrm{Sr}$ ratios in local archaeological vertebrates based on environmental signatures, The Science of the Total Environment 648, 2019, 236-252.

Lewis, Coath, Pike 2014

J. Lewis, C. D. Coath, A. W. G. Pike, An improved protocol for ${ }^{87} \mathrm{Sr} /{ }^{86} \mathrm{Sr}$ by laser ablation multi-collector inductively coupled plasma mass spectrometry using oxide reduction and a customised plasma interface, Chemical Geology 390, 2014, 173-181.

Maurer et al. 2012

A.-F. Maurer, S. J. G. Galer, C. Knipper, L. Beierlein, E. V. Nunn, D. Peters, T. Tüthen, K. W. Alt, B. R. Schöne, Bioavailable ${ }^{87} \mathrm{Sr} /{ }^{86} \mathrm{Sr}$ in different environmental samples - effects of anthropogenic contamination and implications for isoscapes in past migration studies, Science of the Total Environment 433, 2012, 216-229.

MONTGOMERY 2010

J. Montgomery, Passports from the past: investigating human dispersals using strontium isotope analysis of tooth enamel, Annals of Human Biology 37, 2010, 325-46.

Montgomery, Evans, Cooper 2007

J. Montgomery, J. A. Evans, R. E. Cooper, Resolving archaeological populations with Sr-isotope mixing models, Applied Geochemistry 22, 2007, 1502-1514.

MülleR-SCheessel 2013

N. Müller-Scheessel (Ed.), ,Irreguläre` Bestattungen in der Urgeschichte: Norm, Ritual, Strafe ...? Akten der Internationalen Tagung in Frankfurt a. M. vom 3. bis 5. Februar 2012. Kolloquien zur Vor- und Frühgeschichte 19, Bonn 2013. 
NANCI 2013

A. NANCI, Ten Cate's Oral Histology: Development, Structure, and Function, $8^{\text {th }}$ edition. St. Louis, Mo. 2013.

NeLson et al. 1986

B. Nelson, M. J. Deniro, M. J. Schoeninger, D. J. De Paolo, Effects of diagenesis on strontium, carbon, nitrogen and oxygen concentration and isotopic composition of bone, Geochimica et Cosmochimica Acta 50, 1986, 1941.

Nielsen-Marsh, Hedges 2000

C. M. Nielsen-Marsh, R. E. M. Hedges, Patterns of diagenesis in bone I: the effects of site environments, Journal of Archaeological Science 27, 2000, 1139-1150.

Oelze, Nehlich, Richards 2012

V. M. Oelze, O. Nehlich, M. P. Richards, 'There's no place like home' - no isotopic evidence for mobility at the early Bronze Age cemetery of Singen, Germany, Archaeometry 54, 2012, 752-778.

PARson et al. 2018

W. Parson, M. Eduardoff, C. Xavier, B. Bertoglio, M. Teschler-Nicola, Resolving the matrilineal relationship of seven Late Bronze Age individuals from Stillfried, Austria, Forensic Science International: Genetics 26, 2018, 148-151.

Price, Burton, Bentley 2002

T. D. Price, J. H. Burton, R. A. Bentley, The characterization of biologically available strontium isotope ratios for the study of prehistoric migration, Archaeometry 44, 2002, 117-135.

Price, Grupe, Schroter 1998

T. D. Price, G. Grupe, P. Schroter, Migration in the Bell Beaker period of central Europe, Antiquity 72, 1998, 405-411.

Price et al. 2004

T. D. Price, C. Knipper, G. Grupe, V. Smrcka, Strontium isotopes and prehistoric human migration: the Bell Beaker period in central Europe, European Journal of Archaeology 7, 2004, 9-40.

Prohaska et al. 2002

T. Prohaska, C. Latkoczy, G. Schultheis, M. Teschler-NicoLA, G. STINGEDER, Investigation of Sr isotope ratios in prehistoric human bones and teeth using laser ablation ICP-MS and ICP-MS after Rb/Sr separation, Journal of Analytical Atomic Spectrometry 17, 2002, 887-891.

RetZMAnn et al. 2017

A. Retzmann, T. Zimmermann, D. Pröfrock, T. Prohaska, J. IrRgEHER, A fully automated simultaneous single-stage separation of $\mathrm{Sr}, \mathrm{Pb}$, and $\mathrm{Nd}$ using DGA Resin for the isotopic analysis of marine sediments, Analytical and Bioanalytical Chemistry 409, 2017, 5463-5480.

RetZMAnn et al. 2019

A. Retzmann, J. Budka, H. Sattmann, J. Irrgeher, T. Prohaska, The New Kingdom population on Sai Island: application of Sr isotopes to investigate cultural entanglement in ancient Nubia, Egypt and the Levant 29, 2019, 857-883.

RYAN et al. 2018

S. E. Ryan, C. Snoeck, Q. G. Crowley, M. G. Babechuk, ${ }^{87} \mathrm{Sr} /{ }^{86} \mathrm{Sr}$ and trace element mapping of geosphere-hydrosphere-biosphere interactions: a case study in Ireland, Applied Geochemistry 92, 2018, 209-224.

SAUter, Wurst, Hoke 1976

F. SAUTER, F. Wurst, E. HoKe, Inhaltsuntersuchung einer späturnenfelderzeitlichen Deckeldose aus Stillfried, Forschungen in Stillfried 2, 1976, 101-109.
SChweissing, Grupe 2003

M. M. Schweissing, G. Grupe, Stable strontium isotopes in human teeth and bone: a key to migration events of the late Roman period in Bavaria, Journal of Archaeological Science 30, 2003, 1373-1383.

Sehrawat, Kaur 2017

J. S. Sehrawat, J. Kaur, Role of stable isotope analyses in reconstructing past life-histories and the provenancing human skeletal remains: a review, Anthropological Review 80, 2017, 243-258.

SHEPHERD et al. 2012

T. J. Shepherd, W. Dirks, C. Manmee, S. Hodgson, D. A. Banks, P. Averley, T. Pless-Mulloli, Reconstructing the life-time lead exposure in children using dentine in deciduous teeth, The Science of the Total Environment 425, 2012, 214-222.

SILLEN 1986

A. Sillen, Biogenic and diagenetic Sr/Ca in Plio-Pleistocene fossils of the Omo Shungura Formation, Paleobiology 12, 1986, 311-323.

SLovak, Paytan 2012

N. M. Slovak, A. Paytan, Applications of Sr isotopes in archaeology. In: M. Baskaran (Ed.), Handbook of Environmental Isotope Geochemistry I. Berlin - Heidelberg 2012, 743-768.

\section{SPERBER 2017}

L. SPERbER, Studien zur spätbronzezeitlichen Chronologie im westlichen Mitteleuropa und in Westeuropa. Monographien des Römisch-Germanischen Zentralmuseums 136, Mainz 2017.

SPONHeimer, Lee-Thorp 2006

M. Sponheimer, J. A. Lee-Thorp, Enamel diagenesis at South African Australopith sites: implications for paleoecological reconstruction with trace elements, Geochimica et Cosmochimica Acta 70, 2006, 1644-1654.

STAPEL 1999

A. STAPEL, Bronzezeitliche Deponierungen im Siedlungsbereich: Altdorf-Römerfeld und Altheim, Landkreis Landshut. Tübinger Schriften zur Ur- und Frühgeschichtlichen Archäologie 3, Münster 1999.

STEPHAN 2009

E. Stephan, Woher stammen die Toten? Strontiumisotopen-Verhältnisse als Herkunftsmarker. In: R. BAumeister (Ed.), Mord im Moor? Die Bronzezeit am Federsee im Spiegel von Archäologie und Naturwissenschaft (Exhibition catalogue, Bad Buchau 2009). Bad Buchau 2009, 36-38.

STrohschneider 1976

M. Strohschneider, Das späturnenfelderzeitliche Gräberfeld von Stillfried, Forschungen in Stillfried 2, 1976, 31-69.

Swoboda et al. 2008

S. Swoboda, M. Brunner, S. F. Boulyga, P. Galler, M. HorACEK, T. Prohaska, Identification of Marchfeld asparagus using $\mathrm{Sr}$ isotope ratio measurements by MC-ICP-MS, Analytical and Bioanalytical Chemistry 390, 2008, 487-494.

SZILVÁssy, KRITSCHER, Hauser 1988

J. Szilvássy, H. Kritscher, G. Hauser, Eine urnenfelderzeitliche Mehrfachbestattung in Stillfried an der March, NÖ. In: F. FeLgenhauer, J. Szilvássy, H. Kritscher, G. Hauser (Eds.), Stillfried: Archäologie - Anthropologie. Veröffentlichungen des Museums für Ur- und Frühgeschichte Stillfried, Sonderband 3, Stillfried 1988, 9-76. 
Szostek, Mądrzyk, Cienkosz-Stepańczak 2015

K. Szostek, K. Mądrzyk, B. Cienkosz-Stepańczak, Strontium isotopes as an indicator of human migration - easy questions, difficult answers, Anthropological Review 78, 2015, 133-156.

Teschler-Nicola, Irrgeher, Prohaska 2016

M. Teschler-Nicola, J. Irrgeher, T. Prohaska, Wohnsitz und Genealogie der sieben Menschen aus der späturnenfelderzeitlichen Vorratsgrube V1141 von Stillfried an der March: Eine archäometrische Ergänzung anlässlich eines „Schauplatzwechsels“, Mitteilungen der Anthropologischen Gesellschaft Wien 146, 2016, 159-168.

TrautmanN, WaHL 2009

I. Trautmann, J. Wahl, Menschliche Überreste im Moor - fünf Kinder und eine Frau. In: R. Baumeister (Ed.), Mord im Moor? Die Bronzezeit am Federsee im Spiegel von Archäologie und Naturwissenschaft (Exhibition catalogue, Bad Buchau 2009). Bad Buchau 2009, 10-12.

Trautmann, Trautmann, Baumeister 2012

M. Trautmann, I. Trautmann, R. Baumeister, Kindsmord oder Opfertod? Die bronzezeitlichen Schädelfunde von der „Wasserburg Buchau“. In: A. Wieczorek, W. Rosendahl, A. SchlotHAUER (Eds.), Der Kult um Kopf und Schädel: Interdisziplinäre Betrachtungen zu einem Menschheitsthema. Mannheimer Geschichtsblätter, Sonderveröffentlichungen 5, Heidelberg 2012, 25-34.

Trueman et al. 2008

C. N. Trueman, M. R. Palmer, J. Field, K. Privat, N. Ludgate, V. Chavagnac, D. A. Eberth, R. Cifelli, R. R. Rogers, Comparing rates of recrystallisation and the potential for preservation of biomolecules from the distribution of trace elements in fossil bones, Comptes Rendus Palevol 7, 2008, 145-158.

VRÁNA, JANOUŠEK 1999

S. VRÁNA, V. JANOUŠEK, Geochemistry and petrogenesis of granulites in the Lišov granulite massif, Moldanubian zone in southern Bohemia, GeoLines 8, 1999, 74-75.

Wahl, Price 2013

J. Wahl, T. D. Price, Local and foreign males in a Late Bronze Age cemetery at Neckarsulm, south-western Germany: strontium isotope investigations, Anthropologischer Anzeiger 70, 2013, 289-307.

WIESNER 2009

N. WIESNER, Bestattungssitten während der Urnenfelderzeit im südlichen Mitteleuropa: Ein Beitrag zur Entwicklung der Grabsitten in der späten Bronzezeit. Internationale Archäologie 110, Rahden, Westfalen 2009.

Williams et al. 2002

A. M. M. Williams, D. A. Donlon, C. M. Bennett, R. Siegele, Strontium in $19^{\text {th }}$ century Australian children's teeth, Nuclear Instruments and Methods in Physics Research Section B: Beam Interactions with Materials and Atoms 190, 2002, 453-457.

WiLlmes et al. 2016

M. Willmes, L. Kinsley, M. H. Moncel, R. A. Armstrong, M. Aubert, S. EgGins, R. Grün, Improvement of laser ablation in situ micro-analysis to identify diagenetic alteration and measure strontium isotope ratios in fossil human teeth, Journal of Archaeological Science 70, 2016, 102-116.
Wilson, Pollard 2002

L. Wilson, M. Pollard, Here today, gone tomorrow? Integrated experimentation and geochemical modeling in studies of archaeological diagenetic change, Accounts of Chemical Research 35, 2002, 644-651.

WILTSCHKE-SCHROTTA 2006

K. Wiltschke-SchrotTa, Stillfried - Grube V841 (1985/86): Eine anthropologische, detektivische Herausforderung. In: I. HeLLERSCHMID, Die urnenfelder-/hallstattzeitliche Wallanlage von Stillfried an der March: Ergebnisse der Ausgrabungen 19691989 unter besonderer Berücksichtigung des Kulturwandels an der Epochengrenze Urnenfelder-/Hallstattkultur. Mitteilungen der Prähistorischen Kommission 63, Vienna 2006, 414-415.

Wiltschke-Schrotta, Marschler in prep.

K. Wiltschke-Schrotta, M. Marschler, Die menschlichen Überreste aus den Gruben von Stillfried an der March/NÖ. In: I. Hellerschmid, M. Griebl, Die späturnenfelderzeitlichen Tier- und Menschenniederlegungen von Stillfried an der March und die Stratigraphie der Wallbefestigung. Mitteilungen der Prähistorischen Kommission, in preparation.

YANG et al. 2008

L. Yang, C. Peter, U. Panne, R. E. Sturgeon, Use of Zr for mass bias correction in strontium isotope ratio determinations using MC-ICP-MS, Journal of Analytical Atomic Spectrometry 23, 2008, 1269-1274.

ZITEK et al. 2015

A. Zitek, A. TChaikovsky, J. Irrgeher, H. Waidbacher, T. Prohaska, The ${ }^{87} \mathrm{Sr} /{ }^{86} \mathrm{Sr}$ river water isoscape of the Danube catchment. In: ICPDR, Joint Danube Survey 3: A Comprehensive Analysis of Danube Water Quality. Vienna 2015, 349-354.

ZOFFMANN 2001

Z. Zoffmann, Anthropological remains from the Urnfield Period site of Gór-Kápolnadomb. In: A. Lippert (Ed.), Die Drau-, Mur- und Raab-Region im 1. vorchristlichen Jahrtausend. Akten des internationalen interdisziplinären Symposiums vom 26. bis 29. April 2000 in Bad Radkersburg. Universitätsforschungen zur Prähistorischen Archäologie 78, Bonn 2001, 269-270.

Anika Retzmann
Chair of General and Analytical Chemistry
Montanuniversität Leoben
Franz Josef-Straße 18
8700 Leoben
Austria

Department of Chemistry,

Division of Analytical Chemistry

University of Natural Resources and Life Sciences Vienna

VIRIS Laboratory

Konrad-Lorenz-Straße 24

3430 Tulln

Austria

anika.retzmann@unileoben.ac.at

orcid.org/0000-0002-0208-5453 
Anna-Maria Kriechbaum Department of Chemistry, Division of Analytical Chemistry University of Natural Resources and Life Sciences Vienna VIRIS Laboratory Konrad-Lorenz-Straße 24 3430 Tulln Austria annamaria.kriechbaum@yaboo.de (i) orcid.org/0000-0001-6236-3526

Monika Griebl Institute for Oriental and European Archaeology Austrian Academy of Sciences Hollandstraße 11-13 1020 Vienna Austria monika.griebl@oeaw.ac.at orcid.org/0000-0002-3552-7115

Karin Wiltschke-Schrotta Department of Antbropology Natural History Museum Vienna Burgring 7 1010 Vienna Austria karin.wiltschke@nbm-wien.ac.at orcid.org/0000-0002-8321-5095

Maria Teschler-Nicola Department of Antbropology Natural History Museum Vienna Burgring 7 1010 Vienna Austria maria.teschler@nbm-wien.ac.at $\varepsilon$

Department of Evolutionary Anthropology University of Vienna Althanstraße 14 1090 Vienna Austria orcid.org/0000-0003-3080-3085

Johanna Irrgeber Chair of General and Analytical Chemistry Montanuniversität Leoben Franz Josef-Straße 18 8700 Leoben Austria jobanna.irrgeber@unileoben.ac.at orcid.org/0000-0003-3192-0101
Chair of General and Analytical Chemistry Montanuniversität Leoben Franz Josef-Straße 18 8700 Leoben Austria thomas.probaska@unileoben.ac.at D orcid.org/0000-0001-9367-8141 